Nevada

Environmental

Restoration

Project

Post-Closure Report for Closed

Resource Conservation and

Recovery Act Corrective Action

Units, Nevada Test Site, Nevada

For Fiscal Year 2008

(October 2007-September 2008)

Controlled Copy No::

Revision: 0

December 2008

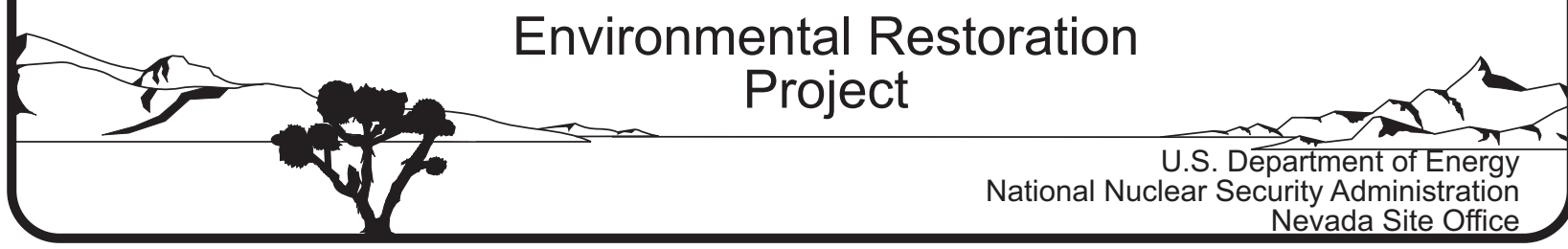




\section{DISCLAIMER}

Reference herein to any specific commercial product, process, or service by trade name, trademark, manufacturer, or otherwise, does not necessarily constitute or imply its endorsement, recommendation, or favoring by the U.S. Government.

This report has been reproduced directly from the best available copy.

Available for sale to the public from:

U.S. Department of Commerce

National Technical Information Service

5285 Port Royal Road

Springfield, VA 22161-0002

Telephone: (800) 553-6847

Fax: (703) 605-6900

E-mail: orders@ntis.gov

Online ordering: http://www.ntis.gov/ordering.htm

Available electronically at http://www.osti.gov/bridge.

Available for a processing fee to the U.S. Department of Energy and its contractors, in paper, from:

U.S. Department of Energy

Office of Scientific and Technical Information

P.O. Box 62

Oak Ridge, TN 37831-0062

Telephone: (865) 576-8401

Fax: (865) 576-5728

E-mail: reports@adonis.osti.gov 


\title{
POST-CLOSURE REPORT FOR CLOSED RESOURCE CONSERVATION AND RECOVERY ACT CORRECTIVE ACTION UNITS, NEVADA TEST SITE, NEVADA \\ FOR FISCAL YEAR 2008 \\ (OCTOBER 2007-SEPTEMBER 2008)
}

\author{
U.S. Department of Energy, \\ National Nuclear Security Administration \\ Nevada Site Office \\ Las Vegas, Nevada
}

Controlled Copy No.

Revision: 0

December 2008 
THIS PAGE INTENTIONALLY LEFT BLANK 


\title{
POST-CLOSURE REPORT FOR CLOSED RESOURCE CONSERVATION AND RECOVERY ACT CORRECTIVE ACTION UNITS, NEVADA TEST SITE, NEVADA
}

\author{
FOR FISCAL YEAR 2008 \\ (OCTOBER 2007-SEPTEMBER 2008)
}

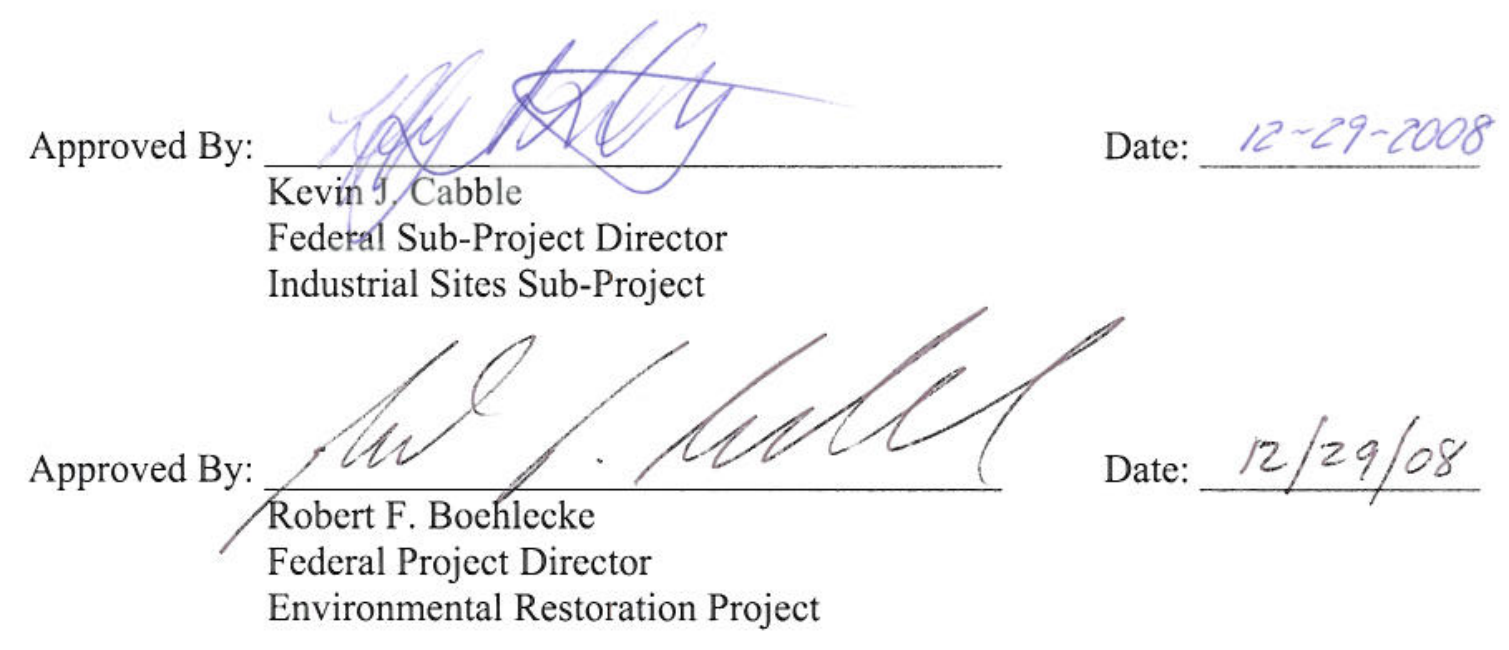


THIS PAGE INTENTIONALLY LEFT BLANK 


\section{TABLE OF CONTENTS}

ACRONYMS AND ABBREVIATIONS …………............................................................... vii

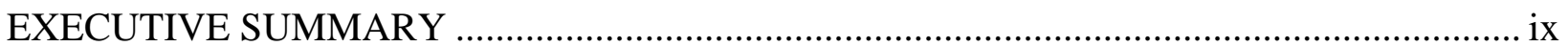

1.0 SUMMARY OF INSPECTIONS, REPAIRS, AND MAINTENANCE................................ 1

1.1 CoRRECTIVE Action Unit 90, AREA 2 BitCUTTER ConTAINMENT ………………….... 1

1.1.1 Resource Conservation and Recovery Act Permit Requirements..................... 1

1.1.2 Inspection, Repair, and Maintenance Activities ................................................ 1

1.2 Corrective Action Unit 91, AREA 3 U-3Fi InJection WeLL..................................... 1

1.2.1 Resource Conservation and Recovery Act Permit Requirements...................... 1

1.2.2 Inspection, Repair, and Maintenance Activities ............................................... 1

1.3 Corrective Action Unit 92, ARea 6 Decon Pond FACILITY ................................... 2

1.3.1 Resource Conservation and Recovery Act Permit Requirements..................... 2

1.3.2 Inspection, Repair, and Maintenance Activities ................................................ 2

1.4 Corrective Action Unit 110, Area 3 WMD U-3AX/Bl Crater .............................. 3

1.4.1 Resource Conservation and Recovery Act Permit Requirements...................... 3

1.4.2 Inspection, Repair, and Maintenance Activities .................................................. 3

1.5 Corrective Action Unit 112, Area 23 Hazardous Waste Trenches ................... 3

1.5.1 Resource Conservation and Recovery Act Permit Requirements..................... 3

1.5.2 Inspection, Repair, and Maintenance Activities .................................................. 4

2.0 CORRECTIVE ACTION UNIT 110 SUBSIDENCE AND VEGETATION SURVEY

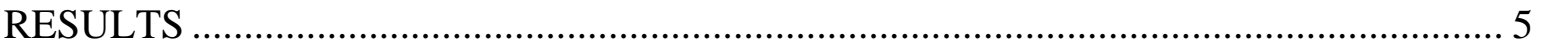

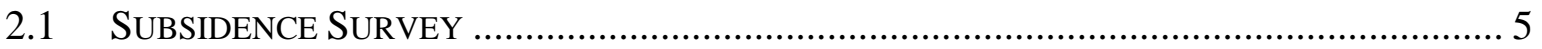

2.2 VEGETATION SURVEY.................................................................................... 5

3.0 CORRECTIVE ACTION UNIT 110 SOIL MOISTURE MONITORING RESULTS ........ 9

4.0 RECOMMENDATIONS AND CONCLUSIONS ............................................................ 17

4.1 CoRrective ACTION Unit 90, AREa 2 BitcutTER ConTAinMENT .............................. 17

4.2 Corrective Action Unit 91, AREA 3 U-3Fi InJeCtion WeLL.................................... 17

4.3 Corrective Action Unit 92, ARea 6 Decon Pond Facility ................................. 17

4.4 Corrective Action Unit 110, Area 3 WMD U-3AX/Bl Crater ............................ 17

4.5 Corrective Action Unit 112, Area 23 Hazardous Waste Trenches ................. 18

LIBRARY DISTRIBUTION LIST

\section{FIGURES}

Figure 1. LoCations of Closed ResourCe Conservation AND ReCOVERY ACt CORRECTIVE

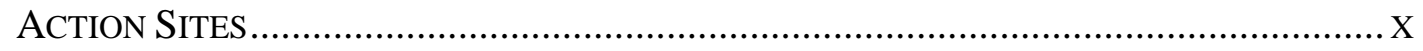

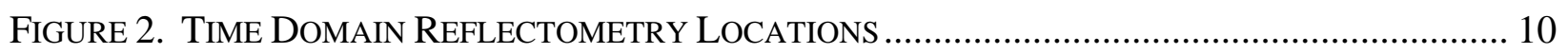

Figure 3. Precipitation Data for Meteorological Station Buster Jangle Y .................. 11

Figure 4. East TDR Nest A Soil Moisture Content Profile .................................................. 12

Figure 5. EAst TDR Nest B SoIL Moisture Content Profile ……………........................... 13

Figure 6. West TDR Nest A Soil Moisture Content ProfiLe ................................................. 14 
Date: December 2008

\section{TABLE OF CONTENTS (continued)}

Figure 7. West TDR Nest B SoIL Moisture Content Profile ................................................. 15

\section{TABLES}

TABLE 1. CorRective Action Unit 110 SubSidence SuRvey ReSUltS ......................................... 6

\section{APPENDICES}

APPENDIX A. INSPECTION CHECKLISTS

APPENDIX B. FIELD NOTES

APPENDIX C. PHOTOGRAPHS 
Date: December 2008

\section{ACRONYMS AND ABBREVIATIONS}

CAU

FFACO

$\mathrm{ft}$

FY

in.

NDEP

SM

TDR
Corrective Action Unit

Federal Facility Agreement and Consent Order

foot (feet)

fiscal year

inch(es)

Nevada Division of Environmental Protection

subsidence marker

Time Domain Reflectometry 
RCRA Post-Closure Report

Revision: 0

Date: December 2008

\section{THIS PAGE INTENTIONALLY LEFT BLANK}




\section{EXECUTIVE SUMMARY}

This report is the first combined annual report for post-closure activities for the following closed Corrective Action Units (CAUs):

- CAU 90, Area 2 Bitcutter Containment

- CAU 91, Area 3 U-3fi Injection Well

- CAU 92, Area 6 Decon Pond Facility

- CAU 110, Area 3 WMD U-3ax/bl Crater

- CAU 112, Area 23 Hazardous Waste Trenches

The locations of the sites are shown in Figure 1. This report covers fiscal year (FY) 2008 (October 2007-September 2008). Because this is the first combined annual report for these CAUs, this report only covers the period not covered in the previous annual report for each CAU. For example, the last report submitted for CAU 91 covered the period January 2007December 2007; therefore, this report only covers the remainder of FY2008 (January 2008September 2008) for CAU 91. The post-closure requirements for these sites are described in Resource Conservation and Recovery Act Permit Number NEV HW0021 and summarized in each CAU-specific section in Section 1.0 of this report.

Site inspections are conducted semiannually at CAUs 90 and 91 and quarterly at CAUs 92, 110, and 112. Additional inspections are conducted at CAU 92 if precipitation occurs in excess of 0.50 inches in a 24-hour period. Inspections include an evaluation of the condition of the units and identification of any deficiencies that may compromise the integrity of the units. The condition of covers, fencing, signs, gates, and locks is documented. In addition, soil moisture monitoring and subsidence surveys are conducted at CAU 110. The results of the inspections, summary of maintenance activities, results of vegetations surveys, and analysis of monitoring data are presented in this report.

Copies of the inspection checklists are included as Appendix A. Field notes completed during each inspection are included in Appendix B. Photographs taken during the site inspections are included in Appendix C. 


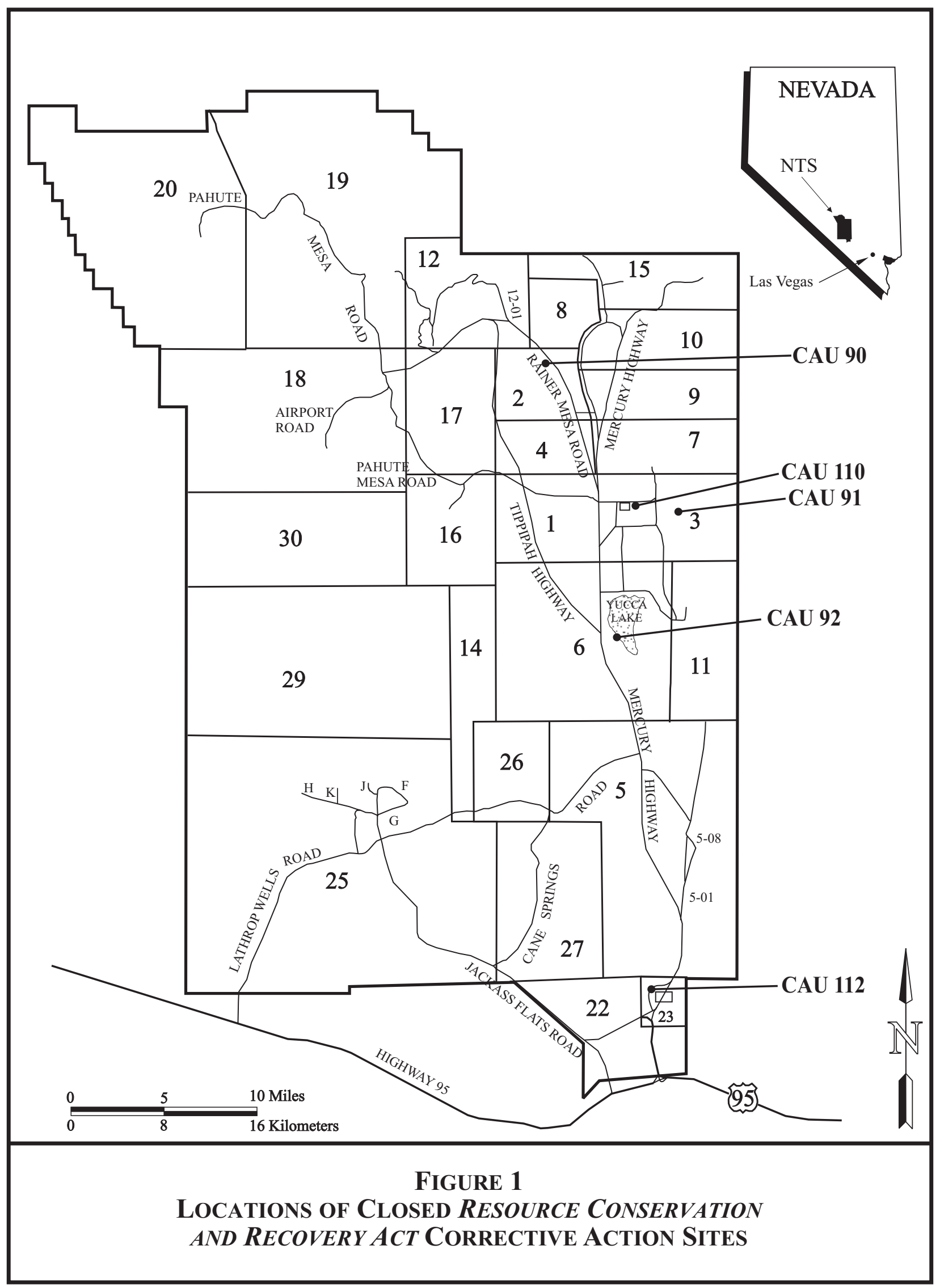




\subsection{SUMMARY OF INSPECTIONS, REPAIRS, AND MAINTENANCE}

\subsection{Corrective Action Unit 90, Area 2 Bitcutter Containment}

\subsubsection{Resource Conservation and Recovery Act Permit Requirements}

Inspections are required at Corrective Action Unit (CAU) 90 twice per year and include an evaluation of the condition of the unit and identification of any deficiencies that may compromise the integrity of the unit. Photographs of the unit are taken during the inspection, and the results of the inspection are documented on an inspection checklist. Any deficiencies that require maintenance other than general housekeeping issues are reported to the Nevada Division of Environmental Protection (NDEP) and remedied within 60 days of discovery.

\subsubsection{Inspection, Repair, and Maintenance Activities}

The last report submitted for CAU 90 covered the period July 2007-June 2008; therefore, this report covers the remainder of fiscal year (FY) 2008 (July 2008-September 2008) for CAU 90. The last semiannual inspection was performed on June 17, 2008, and the results were reported in the last annual report. The next semiannual inspection is scheduled for December 2008, and the results will be reported in the next annual report.

During the last semiannual inspection, vegetation was noted on the cover, and vegetation removal and herbicide application were recommended. Vegetation removal activities and herbicide application were completed on August 7, 2008. It was also recommended to replace the use restriction warning signs as a best management practice to meet current Federal Facility Agreement and Consent Order (FFACO) posting guidelines. This activity is planned for FY2009 and will be reported in the next annual report.

\subsection{Corrective Action Unit 91, Area 3 U-3Fi InJection Well}

\subsubsection{Resource Conservation and Recovery Act Permit Requirements}

Inspections are required at CAU 91 twice per year and include an evaluation of the condition of the unit and identification of any deficiencies that may compromise the integrity of the unit. Photographs of the unit are taken during the inspection, and the results of the inspection are documented on an inspection checklist. The permit does not specify a time period in which repairs or maintenance are to be completed at CAU 91.

\subsubsection{Inspection, Repair, and Maintenance Activities}

The last report submitted for CAU 91 covered the period January 2007-December 2007; therefore, this report covers the remainder of FY2008 (January 2008-September 2008) for CAU 91. Semiannual inspections were performed on March 26 and September 23, 2008.

During the March semiannual inspection, vegetation was noted within the fenced area, and vegetation removal and herbicide application were recommended. Vegetation is commonly observed during the spring inspections. Signs and fencing were in good condition, and no other 
issues were identified. Vegetation removal activities and herbicide application were completed on May 13, 2008.

During the September semiannual inspection, the cover and fencing were in good condition, and no issues were identified. It was recommended to replace the use restriction warning signs as a best management practice to meet current FFACO posting guidelines. This activity is planned for FY2009 and will be reported in the next annual report.

\subsection{Corrective Action Unit 92, Area 6 Decon Pond Facility}

\subsubsection{Resource Conservation and Recovery Act Permit Requirements}

Inspections are required quarterly at CAU 92 and in the event that precipitation occurs in excess of 0.50 inches (in.) in a 24-hour period. Inspections include an evaluation of the cover and identification of any deficiencies that may compromise the integrity of the cover. Photographs of the unit are taken during the inspection, and the results of the inspection are documented on an inspection checklist. The inspection checklist documents the reason for the inspection (i.e., quarterly or excess precipitation) and any changes in the condition of the cover or fenced area, including, but not limited to, trash or debris within the fenced area, erosion of the cover, vegetation growing on the cover, and animal burrows or nesting activity. The condition of the fencing, wave barrier (fiber glass slats laced through the bottom of the chain-link fencing), use restriction warning signs, entrance gate, and lock is also documented. Any evidence of small cracks or settling imperfections (less than 2 in. deep) on the cover is documented, and repairs are scheduled on an annual basis. Larger disruptions of the cover are immediately reported to NDEP and remedied within 60 days of discovery.

\subsubsection{Inspection, Repair, and Maintenance Activities}

The last report submitted for CAU 92 covered the period January 2007-December 2007; therefore, this report covers the remainder of FY2008 (January 2008-September 2008) for CAU 92. Quarterly inspections were performed on March 26, June 17, and September 23, 2008. Precipitation events in excess of 0.50 in. occurred in January and August 2008, and inspections were performed on January 28 and August 7, 2008.

On January 27, 2008, 0.63 in. of precipitation were recorded, and an inspection was conducted on January 28, 2008. During the inspection, some standing water was noted within the fenceline but not on the cover itself. The signs, fencing, and wave barriers were in good condition, and no issues were identified.

During the March quarterly inspection, vegetation was noted around the perimeter of the cover, and vegetation removal and herbicide application were recommended. The signs, fencing, and wave barriers were in good condition, and no other issues were identified. Vegetation removal activities and herbicide application were completed on May 13, 2008.

During the June quarterly inspection, vegetation was noted around the perimeter of the cover, and vegetation removal and herbicide application were recommended. The fencing and wave barriers were in good condition, and no other issues were identified. Vegetation removal activities and herbicide application were completed on August 7, 2008. It was also recommended to replace the use restriction warning signs as a best management practice to meet 
current FFACO posting guidelines. This activity is planned for FY2009 and will be reported in the next annual report.

On August 4, 2008, 0.73 in. of precipitation were recorded, and an inspection was conducted on August 7, 2008. During the inspection, no standing water was noted on the cover or within the fenceline. The signs, fencing, and wave barriers were in good condition, and no issues were identified.

During the September quarterly inspection, it was recommended to repair damaged sections of the wave barrier. In addition, vegetation was noted on the perimeter of the cover, and vegetation removal was recommended. These repairs were completed within 60 days of the inspection and will be reported in the next annual report. No other issues were identified.

\subsection{Corrective Action Unit 110, Area 3 WMD U-3AX/Bl Crater}

\subsubsection{Resource Conservation and Recovery Act Permit Requirements}

Inspections are required quarterly at CAU 110 to verify that the cover is intact. Photographs of the unit are taken during the inspection, and the results of the inspection are documented on an inspection checklist. The perimeter of the fencing is walked by the inspector, and the condition of the fencing and chicken wire, use restriction warning signs, and entrance gate and lock is documented. In addition, the seven subsidence markers (SMs) are inspected, and any changes in the condition of the cover, including, but not limited to, trash or debris within the fenced area, erosion of the cover, and animal burrows or nesting activity, are documented. Any evidence of non-critical cracks or settling imperfections (equal to or less than 6 in. deep) on the cover is documented, and repairs are scheduled on an annual basis. Cracks or settling imperfections greater than 6 in. deep that extend 3 feet $(\mathrm{ft})$ or more on the cover are reported to NDEP and repaired within 60 days of discovery.

\subsubsection{Inspection, Repair, and Maintenance Activities}

The last report submitted for CAU 110 covered the period July 2007-June 2008; therefore, this report covers the remainder of FY2008 (July 2008-September 2008) for CAU 110. The quarterly inspection performed during this period was completed on September 23, 2008.

During the September quarterly inspection, the fencing, SMs, and cover were in good condition, and no issues were identified. It was recommended to replace the use restriction warning signs as a best management practice to meet current FFACO posting guidelines. This activity is planned for FY2009 and will be reported in the next annual report.

\subsection{Corrective Action Unit 112, Area 23 Hazardous Waste Trenches}

\subsubsection{Resource Conservation and Recovery Act Permit Requirements}

Inspections are required quarterly at CAU 112 and include an evaluation of the condition of the unit and identification of any deficiencies that may compromise the integrity of the unit. The results of the inspection are documented on an inspection checklist. The permit does not specify a time period in which repairs or maintenance are to be completed at CAU 112. 


\subsubsection{Inspection, Repair, and Maintenance Activities}

The last report submitted for CAU 112 covered the period October 2006-September 2007; therefore, this report covers all of FY2008 (October 2007-September 2008) for CAU 112. Quarterly inspections were performed on December 18, 2007, and on March 26, June 17, and September 23, 2008.

During the December quarterly inspection, the fencing, signs, and cover were in good condition, and no issues were identified.

During the March quarterly inspection, vegetation was noted on the cover, and vegetation removal and herbicide application were recommended. In addition, a strand of barbed wire fencing was down, and repair was recommended. The signs and other cover features were in good condition, and no other issues were identified. Vegetation removal activities and herbicide application were completed on May 8, 2008, and fence repair was completed on August 7, 2008.

During the June quarterly inspection, two signs were down. The fencing and cover were in good condition, and no other issues were identified. The two signs were reattached on August 7, 2008. It was also recommended to replace the use restriction warning signs as a best management practice to meet current FFACO posting guidelines. This activity is planned for FY2009 and will be reported in the next annual report.

During the September quarterly inspection, the fencing, signs, and cover were in good condition, and no issues were identified. 


\subsection{CORRECTIVE ACTION UNIT 110 SUBSIDENCE AND VEGETATION SURVEY RESULTS}

\subsection{SUBSIDENCE SURVEY}

Seven SMs are installed on the cover of CAU 110 to determine if subsidence of the cover is occurring. The initial baseline subsidence survey was conducted on December 14, 2000. Subsequent surveys are conducted twice per year and are compared to the December 2000 baseline survey results. Because the last report submitted for CAU 110 covered the period July 2007-June 2008, this report only covers the remainder of FY2008 (July 2008September 2008) for CAU 110. The subsidence survey performed during this period was completed on September 4, 2008.

The subsidence survey results are tabulated in Table 1. No significant subsidence was observed. SM 5 shows the greatest decrease in elevation (-0.09 ft) compared to the baseline survey in 2000 . Calculated subsidence values are negligible and near the resolution of the survey instruments. This indicates that subsidence is not occurring on the cover.

\subsection{VEgETATION SURVEY}

The CAU 110 cover was initially planted with native seed in December 2000. Surveys have been conducted annually to assess the success of the revegetation effort. The last vegetation survey was completed in May 2008, and the results were included in the last report submitted for CAU 110. The next vegetation survey is scheduled for May 2009, and the results will be summarized in the next annual report. 
RCRA Post-Closure Report

Date: December 2008

Table 1. Corrective Action Unit 110 Subsidence Survey Results

\begin{tabular}{|c|c|c|c|c|c|c|c|}
\hline \multirow{3}{*}{ DATE } & SM \#1 & SM \#2 & SM \#3 & SM \#4 & SM \#5 & SM \#6 & SM \#7 \\
\hline & \multicolumn{7}{|c|}{ Elevation at Top of Subsidence Marker ${ }^{1}$} \\
\hline & \multicolumn{7}{|c|}{ Subsidence Since December 2000 Baseline Survey (ft) } \\
\hline \multirow{2}{*}{$\begin{array}{c}\text { December } 2000 \\
\text { Baseline }\end{array}$} & $4,021.84$ & $4,021.28$ & $4,019.83$ & $4,020.99$ & $4,021.87$ & $4,019.25$ & $4,020.52$ \\
\hline & - & - & - & - & - & - & - \\
\hline \multirow{2}{*}{ July 2001} & $4,021.83$ & $4,021.28$ & $4,019.83$ & $4,020.98$ & $4,021.86$ & $4,019.24$ & $4,020.51$ \\
\hline & -0.01 & 0.00 & 0.00 & -0.01 & -0.01 & -0.01 & -0.01 \\
\hline \multirow{2}{*}{ January 2002} & $4,021.84$ & $4,021.28$ & $4,019.83$ & $4,020.98$ & $4,021.86$ & $4,019.24$ & $4,020.51$ \\
\hline & 0.00 & 0.00 & 0.00 & -0.01 & -0.01 & -0.01 & -0.01 \\
\hline \multirow{2}{*}{ September 2002} & $4,021.83$ & $4,021.27$ & $4,019.83$ & $4,020.98$ & $4,021.86$ & $4,019.24$ & $4,020.50$ \\
\hline & -0.01 & -0.01 & 0.00 & -0.01 & -0.01 & -0.01 & -0.02 \\
\hline \multirow{2}{*}{ January 2003} & $4,021.83$ & $4,021.27$ & $4,019.83$ & $4,020.98$ & $4,021.86$ & $4,019.24$ & $4,020.50$ \\
\hline & -0.01 & -0.01 & 0.00 & -0.01 & -0.01 & -0.01 & -0.02 \\
\hline \multirow{2}{*}{ July 2003} & $4,021.83$ & $4,021.27$ & $4,019.83$ & $4,020.97$ & $4,021.85$ & $4,019.24$ & $4,020.50$ \\
\hline & -0.01 & -0.01 & 0.00 & -0.02 & -0.02 & -0.01 & -0.02 \\
\hline \multirow{2}{*}{ March 2004} & $4,021.82$ & $4,021.26$ & $4,019.82$ & $4,020.97$ & $4,021.83$ & $4,019.22$ & $4,020.49$ \\
\hline & -0.02 & -0.02 & -0.01 & -0.02 & -0.04 & -0.03 & -0.03 \\
\hline \multirow{2}{*}{ September 2004} & $4,021.82$ & $4,021.26$ & 4,019.82 & $4,020.96$ & $4,021.83$ & $4,019.23$ & $4,020.49$ \\
\hline & -0.02 & -0.02 & -0.01 & -0.03 & -0.04 & -0.02 & -0.03 \\
\hline \multirow{2}{*}{ March 2005} & $4,021.82$ & $4,021.26$ & $4,019.82$ & $4,020.96$ & $4,021.82$ & $4,019.22$ & $4,020.49$ \\
\hline & -0.02 & -0.02 & -0.01 & -0.03 & -0.05 & -0.03 & -0.03 \\
\hline \multirow{2}{*}{ September 2005} & $4,021.82$ & $4,021.26$ & $4,019.82$ & $4,020.97$ & $4,021.82$ & $4,019.23$ & $4,020.49$ \\
\hline & -0.02 & -0.02 & -0.01 & -0.02 & -0.05 & -0.02 & -0.03 \\
\hline
\end{tabular}


TABle 1. Corrective Action Unit 110 Subsidence Survey Results, Continued

\begin{tabular}{|c|c|c|c|c|c|c|c|}
\hline \multirow{3}{*}{ DATE } & SM \#1 & SM \#2 & SM \#3 & SM \#4 & SM \#5 & SM \#6 & SM \#7 \\
\hline & \multicolumn{7}{|c|}{ Elevation at Top of Subsidence Marker ${ }^{1}$} \\
\hline & \multicolumn{7}{|c|}{ Subsidence Since December 2000 Baseline Survey (ft) } \\
\hline \multirow{2}{*}{ March 2006} & $4,021.82$ & $4,021.26$ & $4,019.82$ & $4,020.96$ & $4,021.82$ & $4,019.23$ & $4,020.49$ \\
\hline & -0.02 & -0.02 & -0.01 & -0.03 & -0.05 & -0.02 & -0.03 \\
\hline \multirow{2}{*}{ September 2006} & $4,021.82$ & $4,021.25$ & $4,019.82$ & $4,020.96$ & $4,021.81$ & $4,019.22$ & $4,020.49$ \\
\hline & -0.02 & -0.03 & -0.01 & -0.03 & -0.06 & -0.03 & -0.03 \\
\hline \multirow{2}{*}{ March 2007} & $4,021.82$ & $4,021.25$ & 4,019.82 & $4,020.96$ & $4,021.80$ & $4,019.22$ & $4,020.48$ \\
\hline & -0.02 & -0.03 & -0.01 & -0.03 & -0.07 & -0.03 & -0.04 \\
\hline \multirow{2}{*}{ September 2007} & $4,021.81$ & $4,021.25$ & $4,019.81$ & $4,020.96$ & $4,021.79$ & $4,019.22$ & $4,020.49$ \\
\hline & -0.03 & -0.03 & -0.02 & -0.03 & -0.08 & -0.03 & -0.03 \\
\hline \multirow{2}{*}{ March 2008} & 4021.81 & $4,021.25$ & $4,019.81$ & $4,020.95$ & $4,021.79$ & $4,019.22$ & $4,020.48$ \\
\hline & -0.03 & -0.03 & -0.02 & -0.04 & -0.08 & -0.03 & -0.04 \\
\hline \multirow{2}{*}{ September 2008} & $4,021.81$ & $4,021.25$ & $4,019.81$ & 4,020.95 & $4,021.78$ & $4,019.21$ & $4,020.48$ \\
\hline & -0.03 & -0.03 & -0.02 & -0.04 & -0.09 & -0.04 & -0.04 \\
\hline
\end{tabular}

\footnotetext{
${ }^{1}$ Elevations based on North American Vertical Datum of $1929 \mathrm{in} \mathrm{ft}$.
} 
RCRA Post-Closure Report

Revision: 0

Date: December 2008

THIS PAGE INTENTIONALLY LEFT BLANK 


\subsection{CORRECTIVE ACTION UNIT 110 SOIL MOISTURE MONITORING RESULTS}

The CAU 110 cover is designed to prevent infiltration into the disposal unit. The cover performance is monitored using Time Domain Reflectometry (TDR) soil water content sensors buried within the waste cover. The TDR probes are buried at depths of 1 to $8 \mathrm{ft}$ below ground surface at 1-ft intervals. The TDR probes are installed at a distance of $165 \mathrm{ft}$ from the edge of the cover. Arrays of eight probes are positioned at four locations across the cover. Figure 2 illustrates the locations of TDR probes on the cover. Moisture content data from the TDR probes are recorded on a daily basis and stored on a data logger. The data are transmitted via radio frequency and downloaded on a quarterly basis.

Precipitation data were collected from meteorological station Buster Jangle Y, located approximately 3 miles northwest of CAU 110. The precipitation data are presented in Figure 2. Graphs of the TDR-derived soil moisture content profiles, combined with the daily precipitation values, are presented in Figures 3 through 6.

Soil moisture results obtained to date indicate that the CAU 110 cover is functioning as designed. Shallow soil moisture content is variable and dependent on precipitation events and the ability of shallow root systems and evapotranspiration to remove moisture from the soil. The ability for these systems to remove moisture can be locally inhibited if animal burrowing and grazing on plants affects the root systems; therefore, small mammals are being trapped and relocated from the cover to limit this damage.

Soil moisture contents for the TDR nests at depth are generally between 9 and 15 percent volumetric moisture content, depending on the location of the nest. Some locations show greater annual variability in moisture content; however, each location appears to have equilibrated to a consistent state for that location.

The point of compliance is the depth of the deepest TDR probe $(8 \mathrm{ft})$. Compliance will be set based on soil moisture content; however, the specific criteria will not be established until the cover has had sufficient time to reach equilibrium. Once the moisture content within the cover reaches equilibrium, soil moisture trigger values will be agreed upon with NDEP. Because the last report submitted for CAU 110 covered the period July 2007-June 2008, this report only covers the remainder of FY2008 (July 2008-September 2008) for CAU 110. A compliance level will be proposed in next year's report if moisture conditions remain within the same moisture content range observed over recent years. 


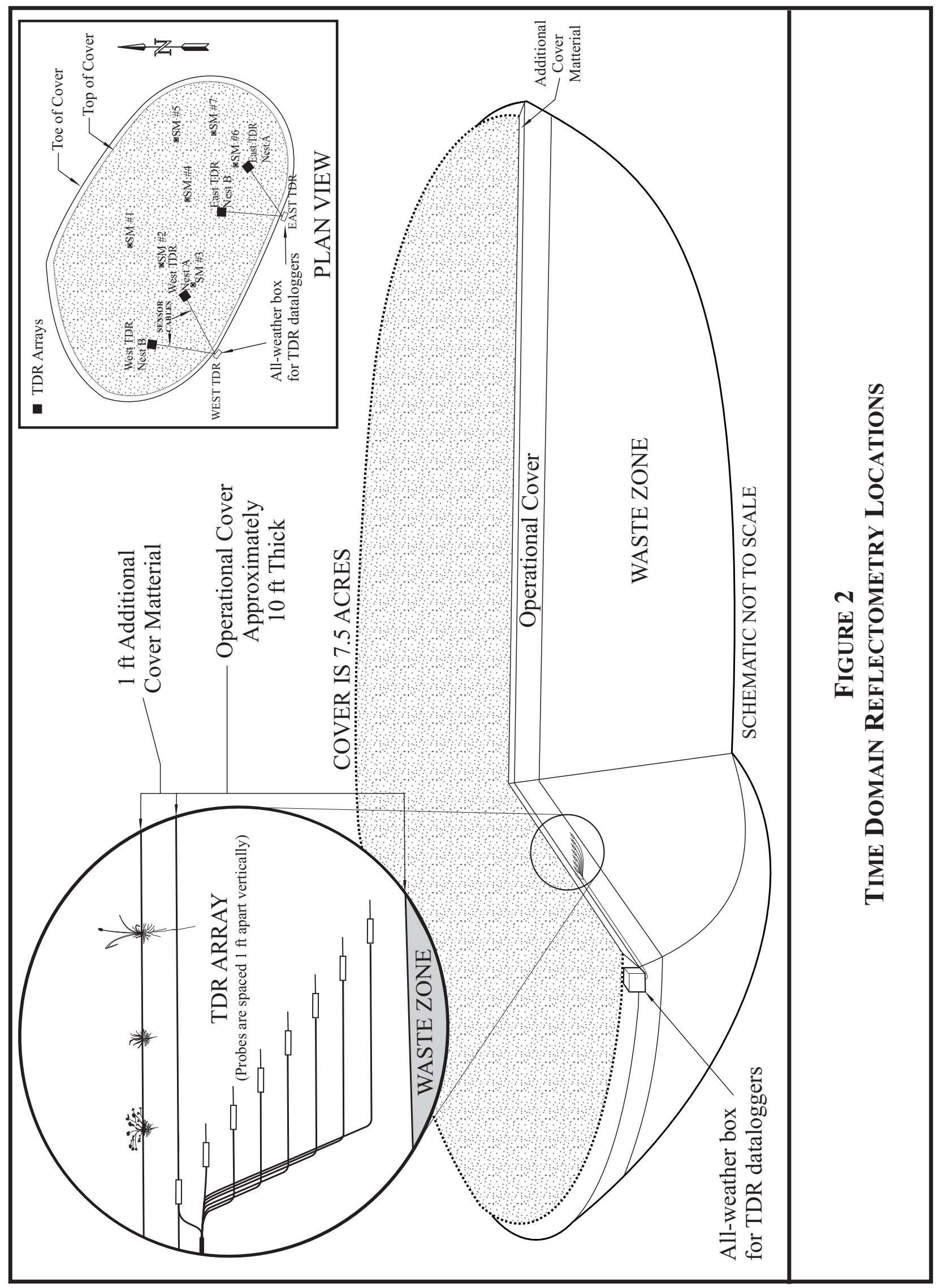




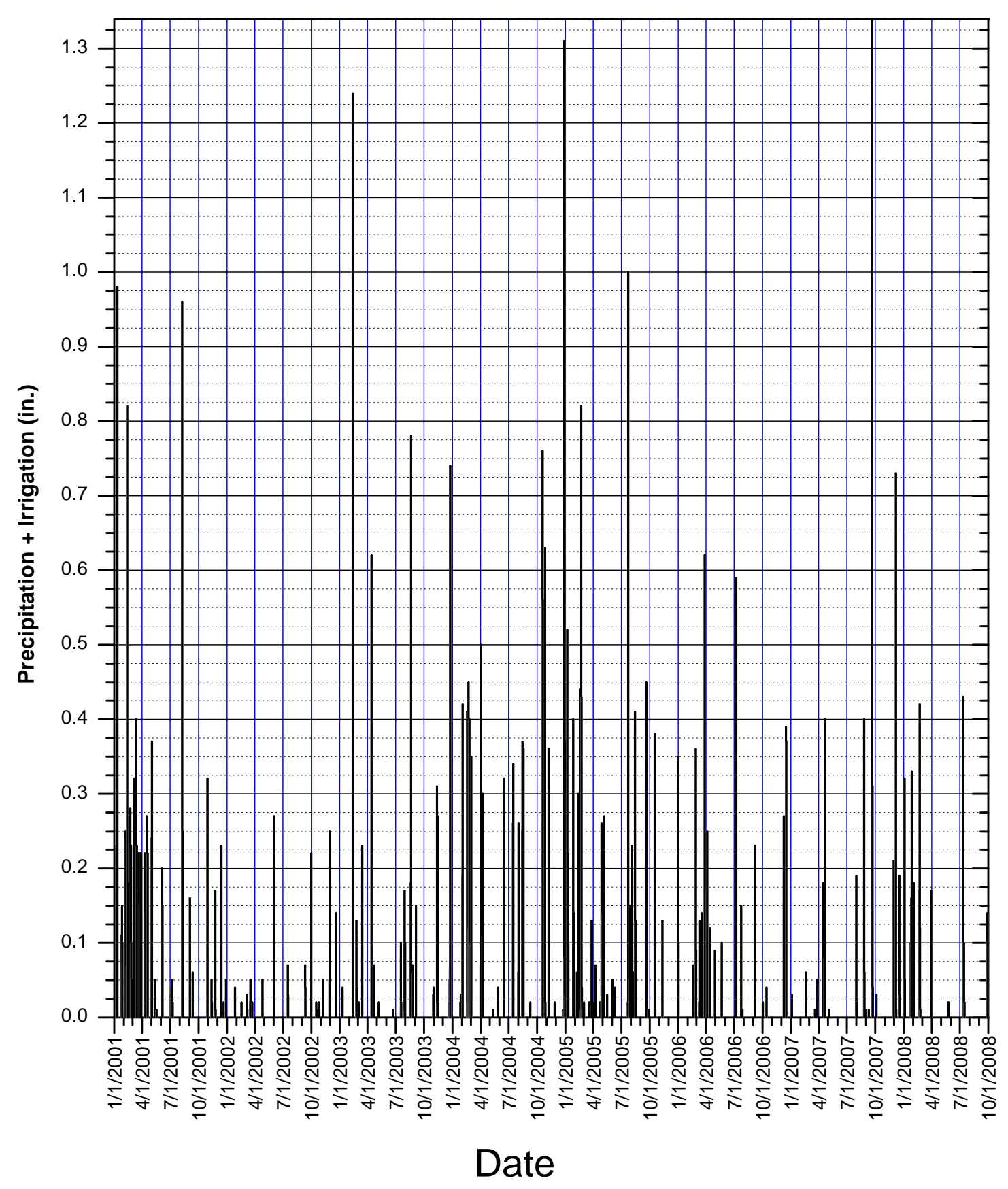

FIGURE 3

PRECIPITATION DATA FOR METEOROLOGICAL STATION BUSTER JANGLE Y 


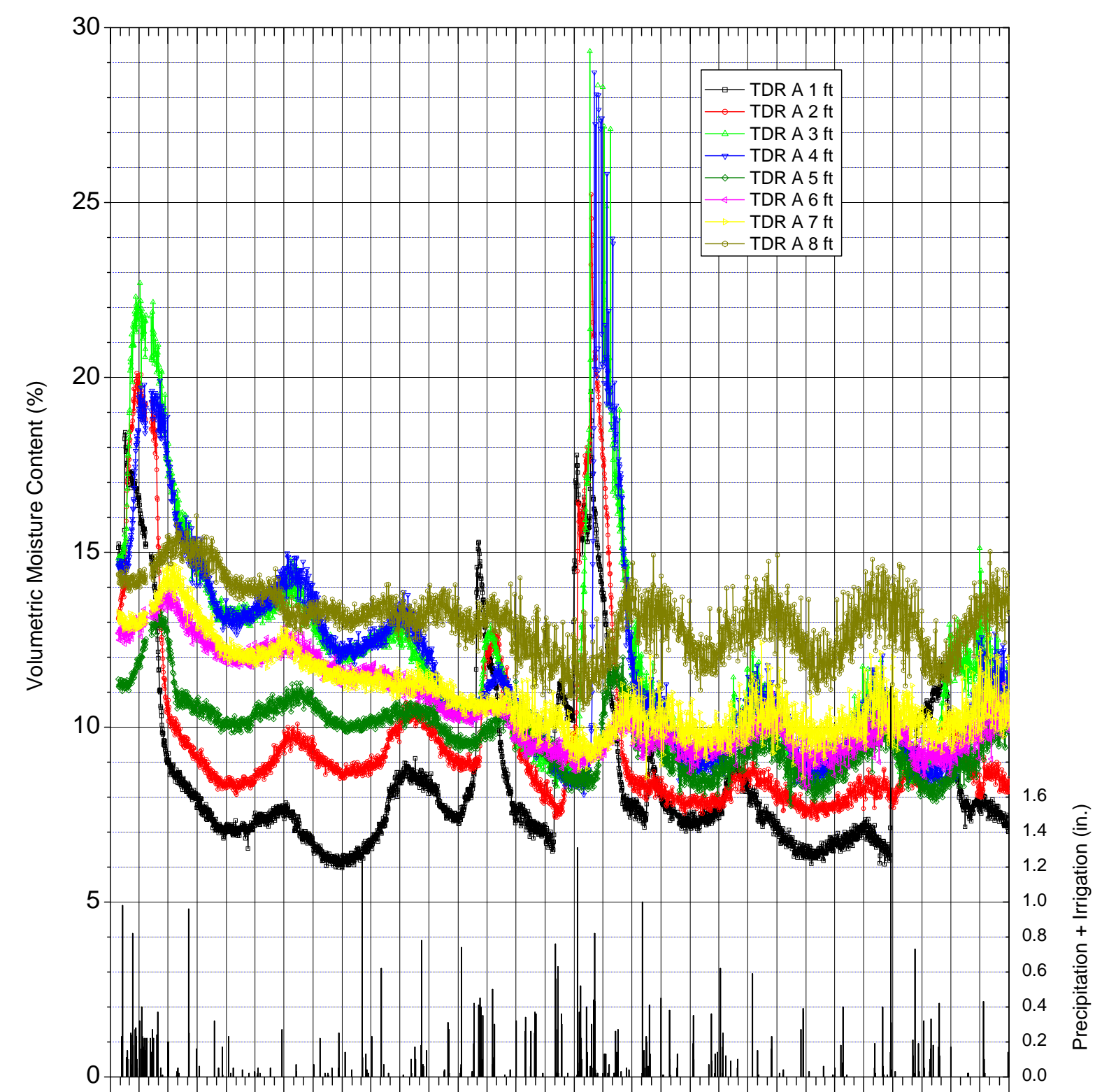

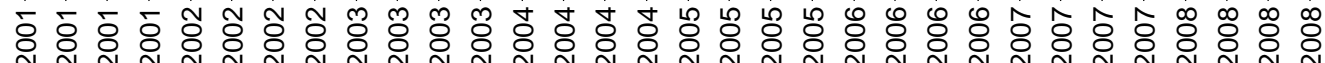

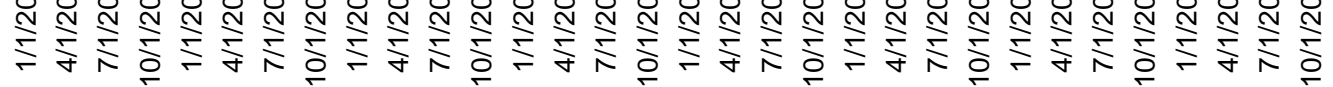
Day of Year

FIGURE 4 EAst TDR Nest A SoIL MOISTURE ConTENT PROFILE 


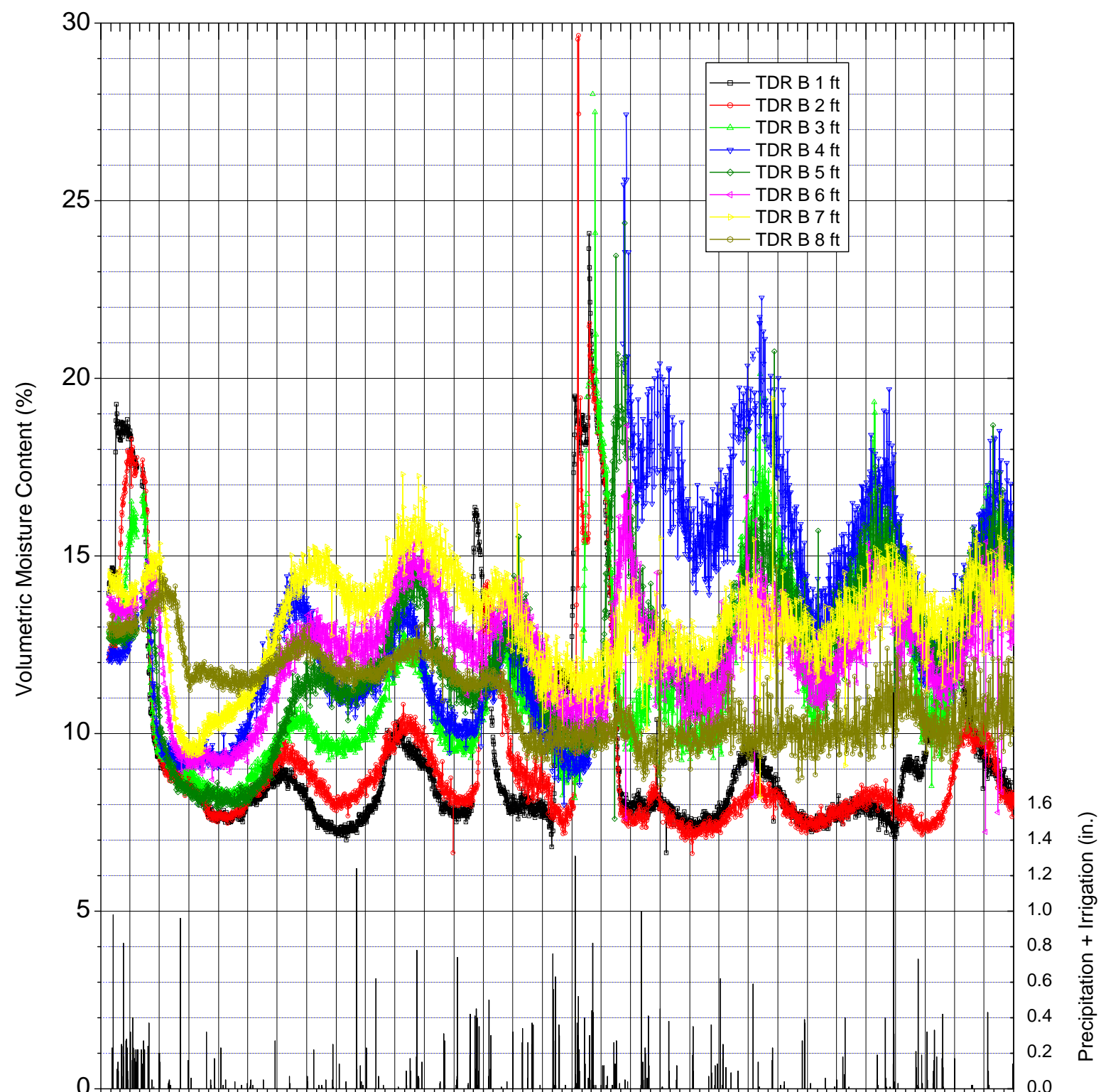

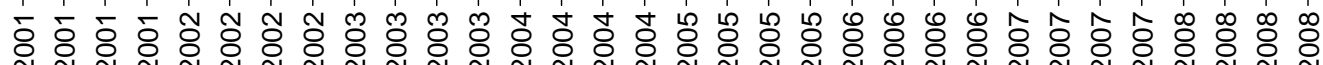

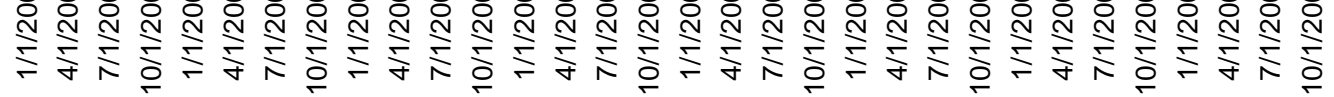
Day of Year

FIGURE 5

EAST TDR NeSt B SoIL MOISTURe ConTent PROfILE 


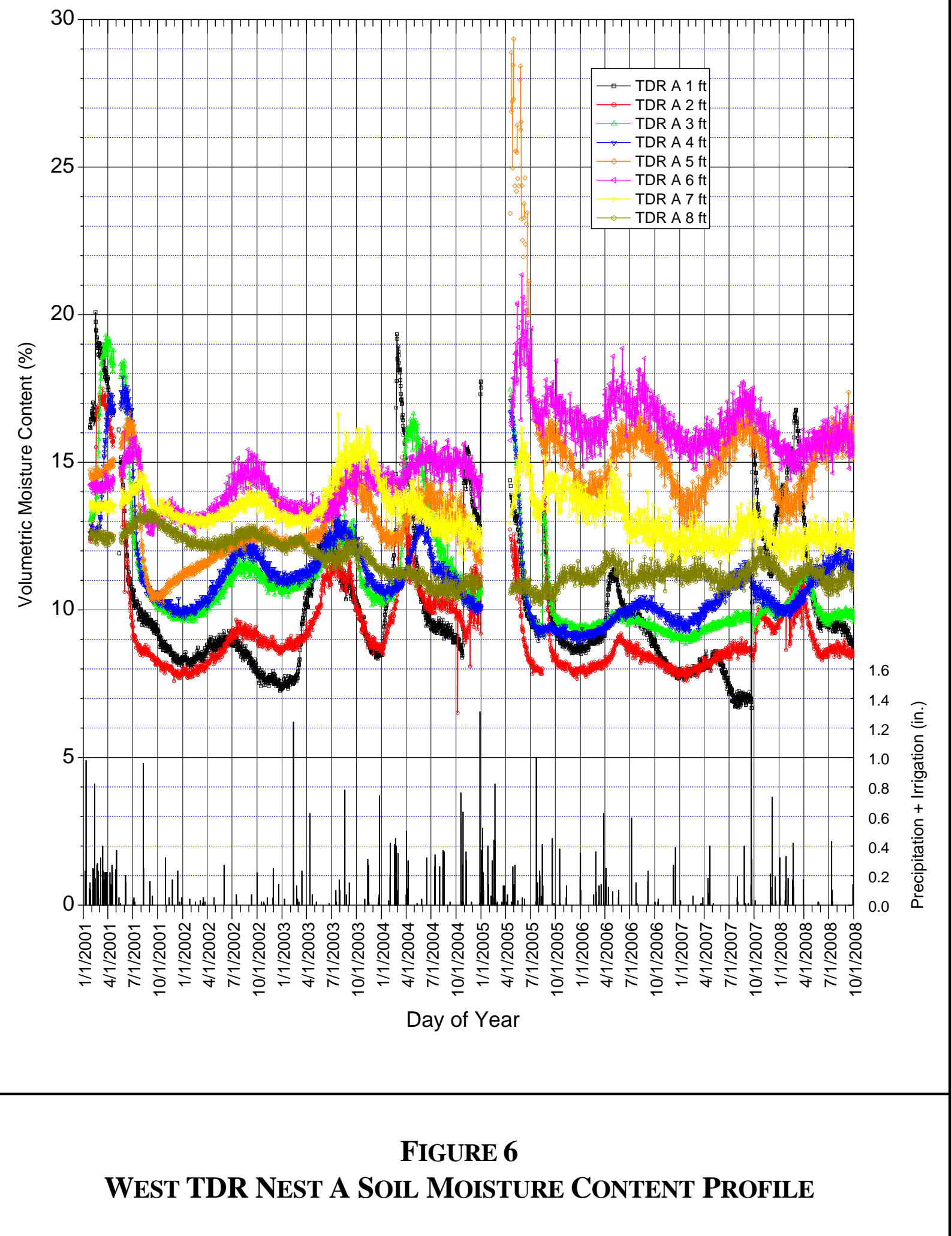




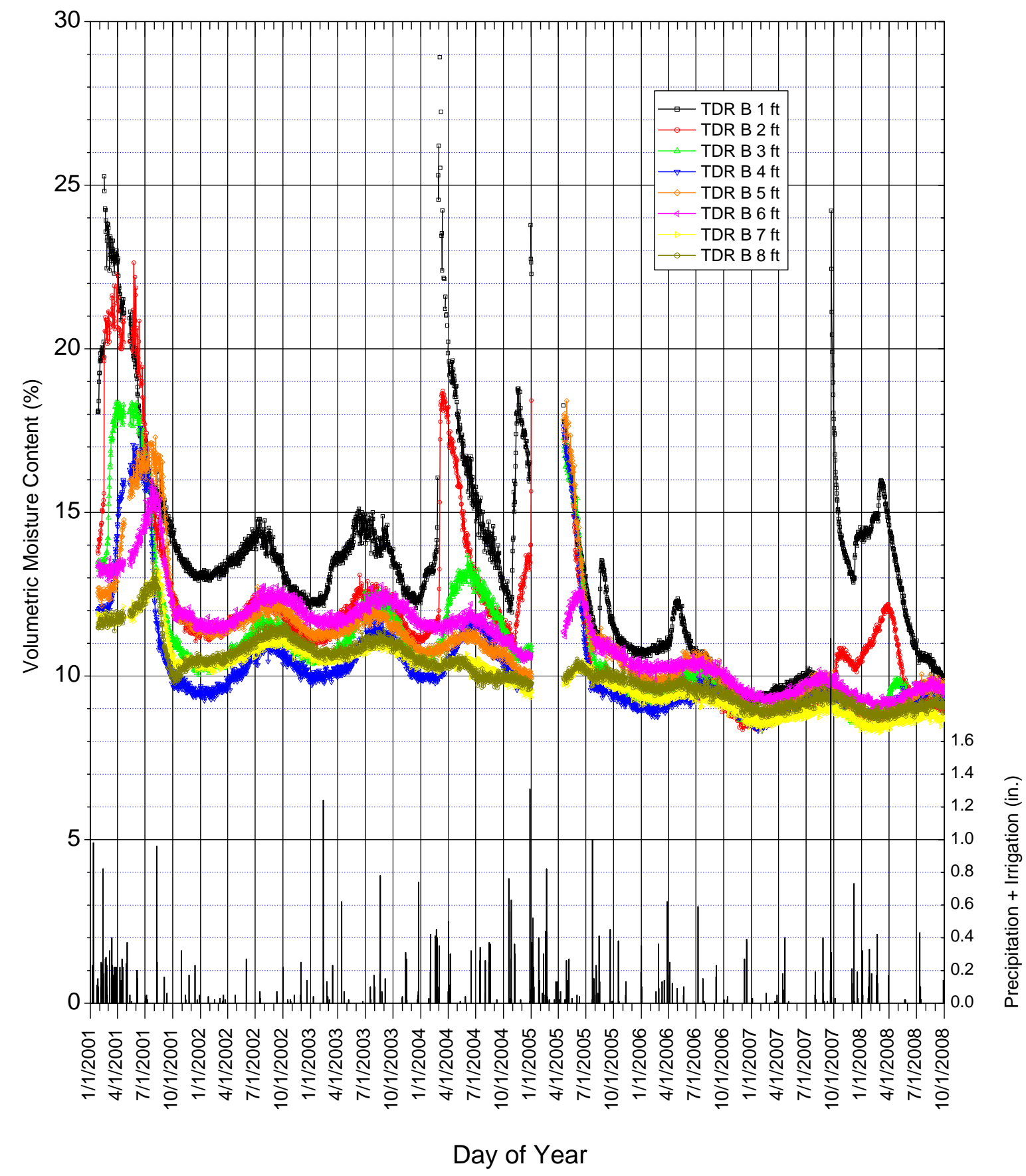

FIGURE 7

West TDR Nest B SoIL Moisture ConTent PRofile 
RCRA Post-Closure Report

Revision: 0

Date: December 2008

THIS PAGE INTENTIONALLY LEFT BLANK 


\subsection{RECOMMENDATIONS AND CONCLUSIONS}

\subsection{Corrective Action Unit 90, Area 2 Bitcutter Containment}

This report covers July 2008-September 2008 for CAU 90. Inspections were not scheduled or performed at CAU 90 during this period. The next semiannual inspection is scheduled for December 2008, and the results will be reported in the next annual report.

It is recommended to continue inspections twice per year to evaluate the condition of the unit and identify any deficiencies that may compromise the integrity of the unit. As a best management practice, the use restriction warning signs will be replaced to meet current FFACO posting guidelines. This activity is planned for FY2009 and will be reported in the next annual report.

\subsection{Corrective Action Unit 91, Area 3 U-3Fi InJection Well}

This report covers January 2008-September 2008 for CAU 91. Semiannual inspections were performed at CAU 91 on March 26 and September 23, 2008. During the last inspection, the unit was in good condition, and no maintenance or repairs were needed.

It is recommended to continue inspections twice per year to evaluate the condition of the unit and identify any deficiencies that may compromise the integrity of the unit. As a best management practice, the use restriction warning signs will be replaced to meet current FFACO posting guidelines. This activity is planned for FY2009 and will be reported in the next annual report.

\subsection{Corrective Action Unit 92, Area 6 Decon Pond Facility}

This report covers January 2008-September 2008 for CAU 92. Quarterly inspections were performed at CAU 92 on March 26, June 17, and September 23, 2008. Precipitation events in excess of 0.50 in. occurred in January and August 2008, and inspections were performed after each event. During the last inspection, it was recommended to repair damaged sections of the wave barrier. In addition, vegetation was noted on the perimeter of the cover, and vegetation removal and herbicide application were recommended. These repairs were completed within 60 days of the inspection and will be reported in the next annual report. No other issues were identified, and no additional maintenance or repairs were needed.

It is recommended to continue quarterly inspections to evaluate the condition of the unit and identify any deficiencies that may compromise the integrity of the unit. As a best management practice, the use restriction warning signs will be replaced to meet current FFACO posting guidelines. This activity is planned for FY2009 and will be reported in the next annual report.

\subsection{Corrective Action Unit 110, Area 3 WMD U-3AX/Bl Crater}

This report covers July 2008-September 2008 for CAU 110. The quarterly inspection performed at CAU 110 during this period was completed on September 23, 2008. During the inspection, the unit was in good condition, and no maintenance or repairs were needed. Subsidence survey results indicate that no significant subsidence of the cover is occurring. Soil moisture results obtained to date indicate that the cover is functioning as designed. 
The following actions are recommended for CAU 110:

- Continue quarterly inspections to evaluate the condition of the unit and identify any deficiencies that may compromise the integrity of the unit.

- Continue subsidence surveys twice per year to determine if subsidence of the cover is occurring.

- Continue to monitor the vegetation on the cover annually to evaluate plant cover, density, and diversity.

- Continue to monitor the soil moisture content and recommend a compliance level if moisture conditions at the compliance depth of $8 \mathrm{ft}$ continue to show that each location remains within the same moisture content range observed over recent years.

As a best management practice, the use restriction warning signs will be replaced to meet current FFACO posting guidelines. This activity is planned for FY2009 and will be reported in the next annual report.

\subsection{Corrective Action Unit 112, Area 23 Hazardous Waste Trenches}

This report covers October 2007-September 2008 for CAU 112. Quarterly inspections were performed at CAU 112 on December 18, 2007, and on March 26, June 17, and September 23, 2008. During the last inspection, the unit was in good condition, and no maintenance or repairs were needed.

It is recommended to continue quarterly inspections to evaluate the condition of the unit and identify any deficiencies that may compromise the integrity of the unit. As a best management practice, the use restriction warning signs will be replaced to meet current FFACO posting guidelines. This activity is planned for FY2009 and will be reported in the next annual report. 
RCRA Post-Closure Report

Revision: 0

Date: December 2008

\section{Appendix A.}

\section{INSPECTION CHECKLISTS}


RCRA Post-Closure Report

Revision: 0

Date: December 2008

THIS PAGE INTENTIONALLY LEFT BLANK 
RCRA Post-Closure Report

Revision: 0

Date: December 2008

CORRECTIVE ACTION UNIT 91 INSPECTION CHECKLISTS 
RCRA Post-Closure Report

Revision: 0

Date: December 2008

THIS PAGE INTENTIONALLY LEFT BLANK 


\section{POST-CLOSURE INSPECTION CHECKLIST}

\section{CAU 91: AREA 3 U-3fi INJECTION WELL - CAS 03-20-03: UD-6 and UD-6s Disposal Holes}

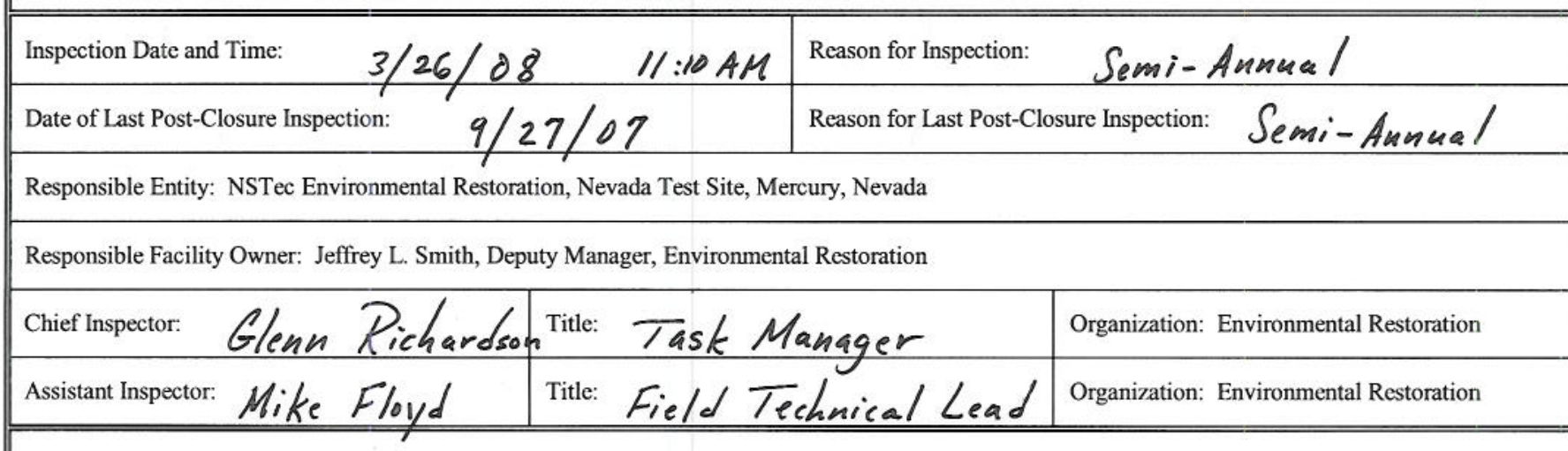

A. GENERAL INSTRUCTIONS

1. All checklist items must be completed and detailed comments made to document the results of the site inspection. The completed checklist is part of the field record of the inspection. Additional pages should be used as necessary to ensure that a complete record is made. Attach the additional pages and number all pages upon completion of the inspection.

2. Any checklist line item marked by an inspector in a SHADED BOX must be fully explained or an appropriate reference to previous reports provided. The purpose of this requirement is to provide a written explanation of inspector observations and the inspector's rationale for conclusions and recommendations. Explanations are to be placed on additional attachments and cross-referenced appropriately. Explanations, in addition to narrative, will take the form of sketches, measurements, and annotated site maps.

3. The site inspection is a walking inspection of the entire site including the perimeter and sufficient transects to be able to inspect the entire surface and all features specifically described in this checklist.

4. A standard set of color photographs is required. In addition, all anomalous features or new features (such as changes in adjacent area land use) are to be photographed. A photograph log entry will be made for each photograph taken. The photographs will be maintained in the project files.

5. Field notes taken to assist in completion of this checklist will become part of the inspection record. No form is specified for field notes; however, they must be legible and in sufficient detail to enable review by succeeding inspectors and the responsible agency.

6. This unit will be inspected semi-annually with formal reporting to the Nevada Division of Environmental Protection to be done annually. The annual letter report will include a summary of the inspection, copies of this inspection checklist, and recommendations and conclusions.

\begin{tabular}{|c|c|c|c|}
\hline B. PREPARATION (To be competed prior to site visit) & YES & NO & EXPLANATION (required if shaded box is checked) \\
\hline 1. Has the Post-Closure Permit been reviewed? & & & \\
\hline \multicolumn{4}{|l|}{ 2. Has the Post-Closure Permit application been reviewed? } \\
\hline \multicolumn{4}{|l|}{ 3. Has the Post-Closure Plan been reviewed? } \\
\hline \multicolumn{4}{|l|}{ 4. Have the site as-built plans and site base map been reviewed? } \\
\hline \multicolumn{4}{|l|}{ 5. Have the previous inspection reports been reviewed? } \\
\hline a. Were anomalies or trends detected on previous inspections? & & & $\begin{array}{l}\text { Vegetation growth was } \\
\text { March } 2007 \text { inspection. }\end{array}$ \\
\hline b. Was maintenance performed? & & & $\begin{array}{l}\text { Vegetation remova/ activities were completed } \\
\text { in May } 2007 \text {. }\end{array}$ \\
\hline $\begin{array}{l}\text { If maintenance was performed, has a copy of the } \\
\text { maintenance records been obtained? }\end{array}$ & & & $\begin{array}{l}\text { NA An electronic copy of the mainfenance reconds } \\
\text { is available and placed on the ER Shared Drive }\end{array}$ \\
\hline \multicolumn{4}{|l|}{ 6. Have the site maintenance and repair records been reviewed? } \\
\hline $\begin{array}{l}\text { a. If so, has site repair resulted in a change from as-built } \\
\text { conditions? }\end{array}$ & & & NA \\
\hline $\begin{array}{l}\text { b. If yes (to } 6 \mathrm{a} \text { ), are revised as-built plans available that reflect } \\
\text { repair changes? }\end{array}$ & & & NA \\
\hline
\end{tabular}


POST-CLOSURE INSPECTION CHECKLIST

\section{CAU 91: AREA 3 U-3fi INJECTION WELL - CAS 03-20-03: UD-6 and UD-6s Disposal Holes}

\section{SITE INSPECTION PREPARATION}

Assemble the following, as needed, to conduct inspections:

a. Camera, film, and batteries

b. Keys to locks

c. Clipboard

d. Tape measure

e. Radio, pager, etc.

f. Previous Post-Closure Report, Inspection Checklists, repair records, and as-built plans

g. Other miscellaneous support equipment

\section{SITE INSPECTION}

1. Adjacent off-site features:

a. Are there any new activities or features in the vicinity that could potentially affect the site (e.g., activities that change the flow of surface water or are encroaching the unit)?

2. Fences, gates, and signs:

a. Is there damage to or a break in the fence?

b. Have any fenceposts been damaged or their anchoring weakened?

c. Is the gate intact and functional?

d. Does the gate show evidence of tampering or damage?

e. Was the gate locked?

f. Are any of the use restriction signs damaged or missing?

g. Are all use restriction signs legible?

h. How many use restriction signs need to be replaced?

i. Other?

4. Waste unit cover:

a. Is there evidence of settling?

b. Is there evidence of cracking?

c. Is there evidence of erosion (wind or water)?

d. Is there evidence of human intrusion onto the cover?

e. Is there evidence of large animal intrusion onto the cover?

f. Is there evidence of animal burrowing?

g. Is vegetation growing on the cover?

h. Other (including trash, debris, etc within fenced area)?

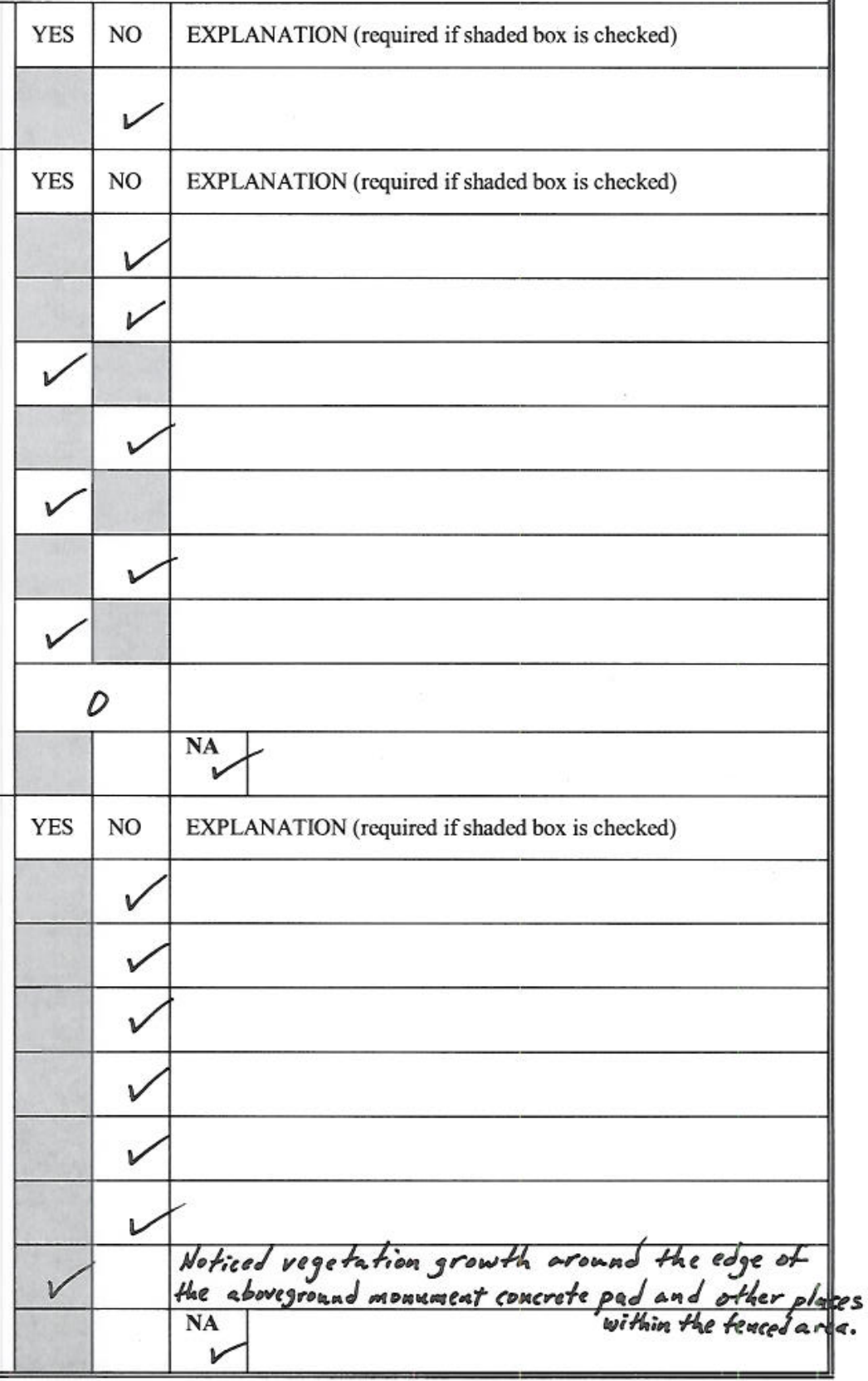


Inspection Requirements: Semi-Annual

\section{POST-CLOSURE INSPECTION CHECKLIST}

\section{CAU 91: AREA 3 U-3fi INJECTION WELL - CAS 03-20-03: UD-6 and UD-6s Disposal Holes}

5. Photograph Instructions:

A total of 10 photographs are required to be taken during each inspection of CAU 91. Additional photographs may also be taken. The required photographs shall be taken as follows:

- Four (4) from the center of the unit, one in each compass direction (i.e., N, S, E, W),

- Four (4) of the unit from outside the fence, one in each compass direction, and

- Two (2) of the ER3-3 monitoring well surface with compass directions ( $\mathrm{N}$ and $\mathrm{S}$ ) noted on the photograph log.

6. Photograph Documentation

a. Have all photographs been taken as required by the photograph instructions?

b. Has a photograph $\log$ been prepared?

c. How many photographs were taken?

d. Other?

\section{E. FIELD CONCLUSIONS}

1. Are more frequent inspections required?

2. Are existing maintenance/repair actions satisfactory?

3. Is other maintenance/repair necessary?

4. Is there an imminent hazard to the integrity of the site?

(Immediate report required)

\begin{tabular}{|c|c|c|}
\hline YES & NO & EXPLANATION (required if shaded box is checked) \\
\hline & & $\begin{array}{l}\text { Log number: An electronic log is available on the } \\
E R \text { Shared drive, under C4n } 91 .\end{array}$ \\
\hline \multicolumn{2}{|c|}{10} & \\
\hline & & NA \\
\hline YES & NO & EXPLANATION (required if shaded box is checked) \\
\hline 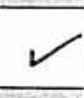 & & $\begin{array}{l}\text { Vegetation removal activities performed in } \\
\text { May } 2007 \text { were satisfactory, but new vegetation grou }\end{array}$ \\
\hline$\checkmark$ & & $\begin{array}{l}\text { Vegetation removal is necessary within discovere } \\
\text { area and especially around the formument comerete ps }\end{array}$ \\
\hline
\end{tabular}

Date reported:

Person/Agency to whom report was made:

5. Field conclusionsirecommendations: The signage and fencing were in good condition. There was no evidence of anima/ burrowing. The aboveground monument was not damaged and in great condition. However, a significunt amount of vegetation growth was noticed around the edges of the aboveground monument concrete pad and in other locations within the UR fenced area. Vegetation removal is reguired within 60 days. Also, an herbicide will beappliadd.

\section{F. CERTIFICATION}

I have conducted an inspection of CAU 91, Area 3 U-3fi Injection Well, in accordance with the procedures of the Post-Closure Permit (including the PostClosure Plan) as recorded on this checklist, attached sheets, field notes, photographs, and photograph logs.

Chief Inspector's Signature:

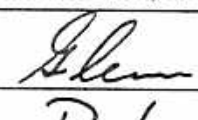

Printed Name:

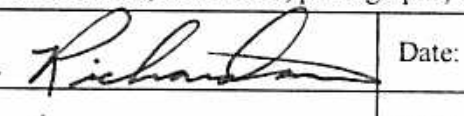

Title:

\section{$3 / 26 / 08$}

Task Manager

Attachments (check if attached):

․ Field Notes

$\square$ Photos

$\square$ Maintenance records 


\section{POST-CLOSURE INSPECTION CHECKLIST}

\section{CAU 91: AREA 3 U-3fi INJECTION WELL - CAS 03-20-03: UD-6 and UD-6s Disposal Holes}

\begin{tabular}{|l|l|}
\hline \hline Inspection Date and Time: $9 / 23 / 08 \quad 10: 10 \mathrm{AM}$ & Reason for Inspection: Semi- Annual \\
\hline Date of Last Post-Closure Inspection: $3 / 26 / 08$ & Reason for Last Post-Closure Inspection: Semi-Annual
\end{tabular}

Responsible Entity: NSTec Environmental Restoration, Nevada Test Site, Mercury, Nevada

Responsible Facility Owner: Thomas A. Thiele, Project Manager, Industrial Sites, Environmental Restoration Project

\begin{tabular}{l|l|l|l|}
\hline Chief Inspector: Glenn Kichardson & Title: Task Manager & Organization: Environmental Restoration \\
\hline Assistant Inspector: Robert Green & Title: Field Techuica/Lead & Organization: Environmental Restoration \\
\hline
\end{tabular}

A. GENERAL INSTRUCTIONS

1. All checklist items must be completed and detailed comments made to document the results of the site inspection. The completed checklist is part of the field record of the inspection. Additional pages should be used as necessary to ensure that a complete record is made. Attach the additional pages and number all pages upon completion of the inspection.

2. Any checklist line item marked by an inspector in a SHADED BOX must be fully explained or an appropriate reference to previous reports provided. The purpose of this requirement is to provide a written explanation of inspector observations and the inspector's rationale for conclusions and recommendations. Explanations are to be placed on additional attachments and cross-referenced appropriately. Explanations, in addition to narrative, will take the form of sketches, measurements, and annotated site maps.

3. The site inspection is a walking inspection of the entire site including the perimeter and sufficient transects to be able to inspect the entire surface and all features specifically described in this checklist.

4. A standard set of color photographs is required. In addition, all anomalous features or new features (such as changes in adjacent area land use) are to be photographed. A photograph log entry will be made for each photograph taken. The photographs will be maintained in the project files.

5. Field notes taken to assist in completion of this checklist will become part of the inspection record. No form is specified for field notes; however, they must be legible and in sufficient detail to enable review by succeeding inspectors and the responsible agency.

6. This unit will be inspected semi-annually with formal reporting to the Nevada Division of Environmental Protection to be done annually. The annual letter report will include a summary of the inspection, copies of this inspection checklist, and recommendations and conclusions.

B. PREPARATION (To be competed prior to site visit)

1. Has the Post-Closure Permit been reviewed?

2. Has the Post-Closure Permit application been reviewed?

3. Has the Post-Closure Plan been reviewed?

4. Have the site as-built plans and site base map been reviewed?

5. Have the previous inspection reports been reviewed?

a. Were anomalies or trends detected on previous inspections?

b. Was maintenance performed?

If maintenance was performed, has a copy of the maintenance records been obtained?

6. Have the site maintenance and repair records been reviewed?

a. If so, has site repair resulted in a change from as-built conditions?

b. If yes (to 6a), are revised as-built plans available that reflect repair changes?

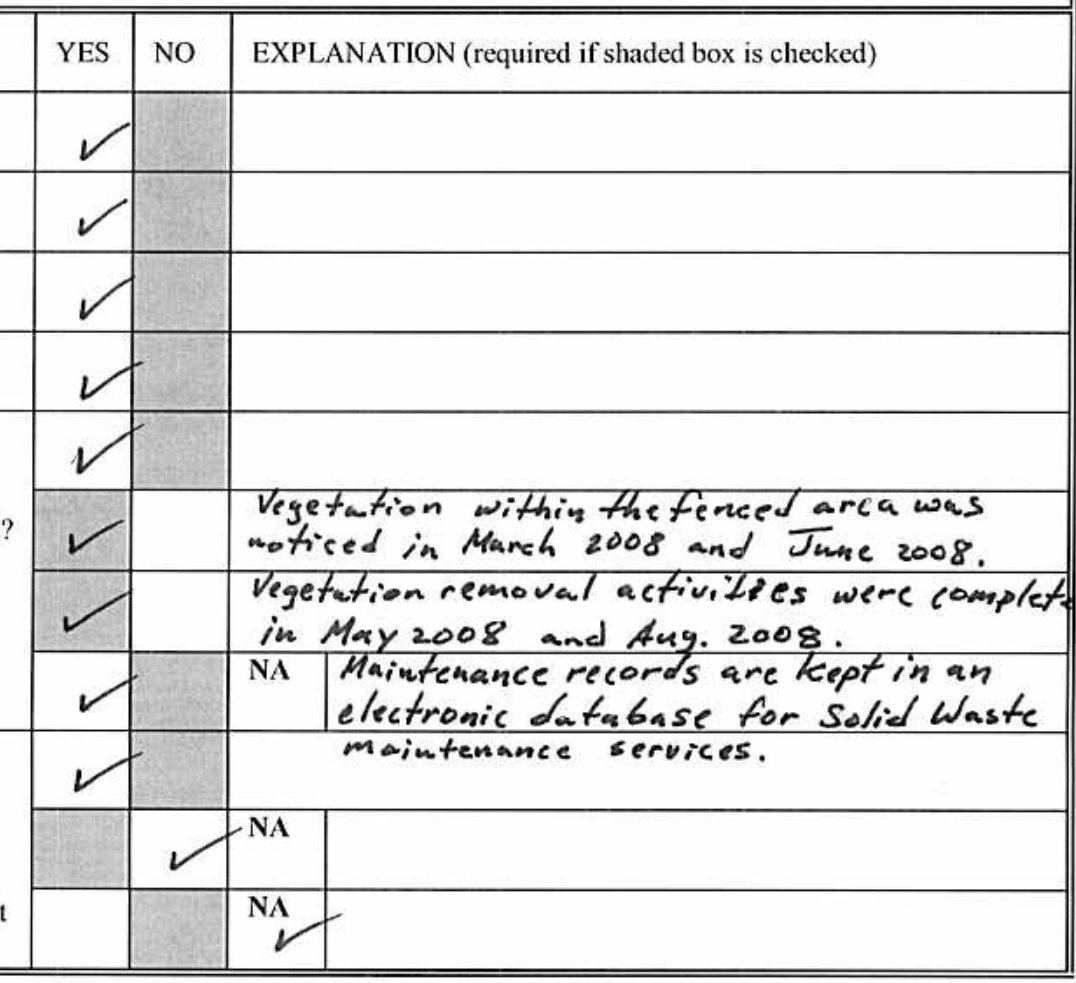




\section{POST-CLOSURE INSPECTION CHECKLIST}

\section{CAU 91: AREA 3 U-3fi INJECTION WELL - CAS 03-20-03: UD-6 and UD-6s Disposal Holes}

\section{SITE INSPECTION PREPARATION}

Assemble the following, as needed, to conduct inspections:

a. Camera, film, and batteries

b. Keys to locks

c. Clipboard

d. Tape measure

e. Radio, pager, etc.

f. Previous Post-Closure Report, Inspection Checklists, repair records, and as-built plans

g. Other miscellaneous support equipment

\section{SITE INSPECTION}

1. Adjacent off-site features:

a. Are there any new activities or features in the vicinity that could potentially affect the site (e.g., activities that change the flow of surface water or are encroaching the unit)?

2. Fences, gates, and signs:

a. Is there damage to or a break in the fence?

b. Have any fenceposts been damaged or their anchoring weakened?

c. Is the gate intact and functional?

d. Does the gate show evidence of tampering or damage?

e. Was the gate locked?

f. Are any of the use restriction signs damaged or missing?

g. Are all use restriction signs legible?

h. How many use restriction signs need to be replaced?

i. Other?

4. Waste unit cover:

a. Is there evidence of settling?

b. Is there evidence of cracking?

c. Is there evidence of erosion (wind or water)?

d. Is there evidence of human intrusion onto the cover?

e. Is there evidence of large animal intrusion onto the cover?

f. Is there evidence of animal burrowing?

g. Is vegetation growing on the cover?

h. Other (including trash, debris, etc within fenced area)?

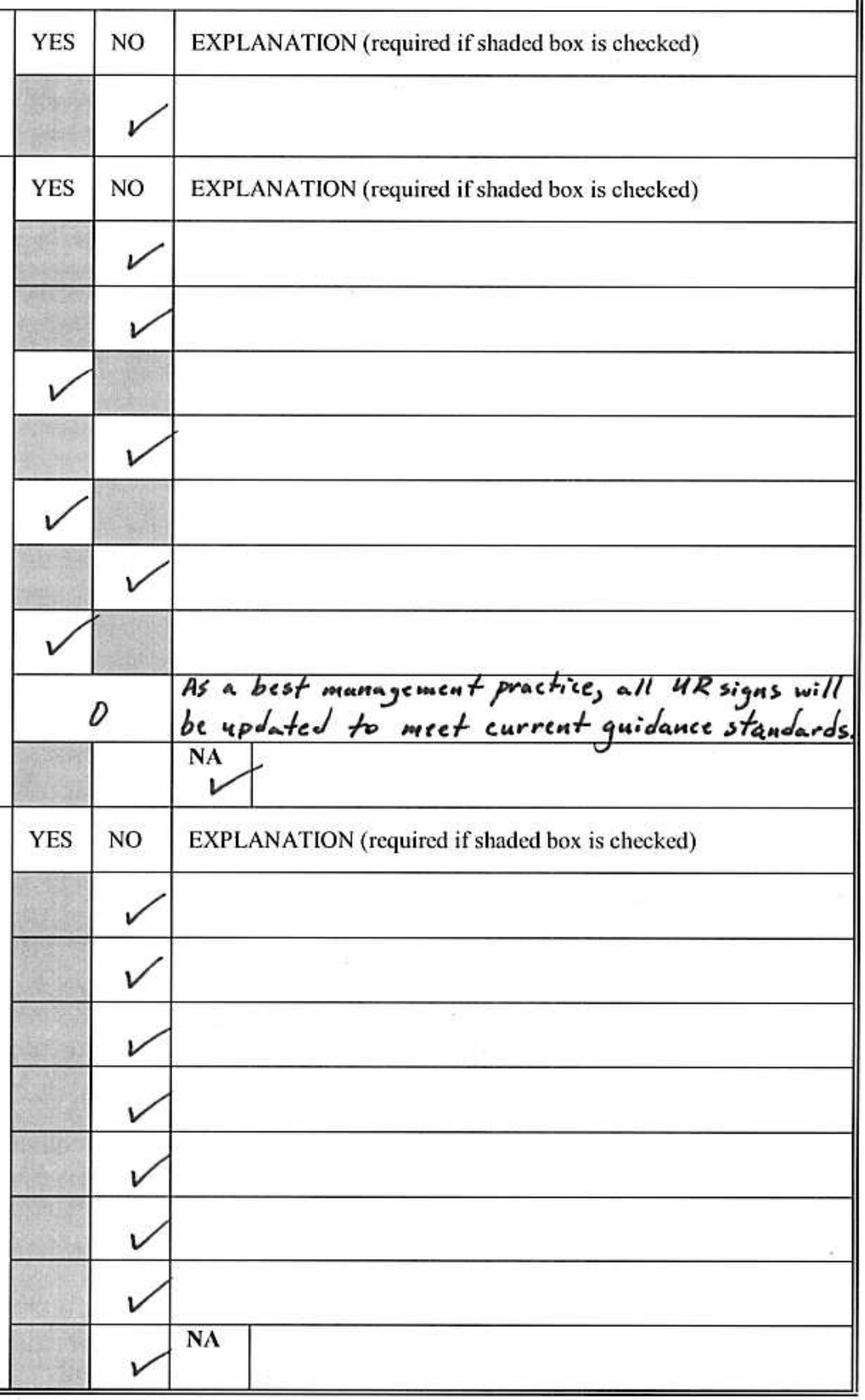




\section{POST-CLOSURE INSPECTION CHECKLIST}

\section{CAU 91: AREA 3 U-3fi INJECTION WELL - CAS 03-20-03: UD-6 and UD-6s Disposal Holes}

5. Photograph Instructions:

A total of 10 photographs are required to be taken during each inspection of CAU 91. Additional photographs may also be taken. The required photographs shall be taken as follows:

- Four (4) from the center of the unit, one in each compass direction (i.e., N, S, E, W),

- Four (4) of the unit from outside the fence, one in each compass direction, and

- Two (2) of the ER3-3 monitoring well surface with compass directions ( $\mathrm{N}$ and $\mathrm{S}$ ) noted on the photograph log.

6. Photograph Documentation:

a. Have all photographs been taken as required by the photograph instructions?

b. Has a photograph log been prepared?

c. How many photographs were taken?

d. Other?

\begin{tabular}{|c|c|c|}
\hline YES & No & EXPLANATION (required if shaded box is checked) \\
\hline$V$ & & $\begin{array}{l}\text { Log number: A photo } \log \text { is available electronically } \\
\text { on the ER shared drive, under }\end{array}$ \\
\hline \multicolumn{2}{|c|}{10} & \\
\hline & & NA \\
\hline YES & NO & EXPLANATION (required if shaded box is checked) \\
\hline & $\nu$ & \\
\hline$\checkmark$ & & \\
\hline & $\nu$ & \\
\hline & & \\
\hline
\end{tabular}

Date reported

Person/Agency to whom report was made:

5. Field conclusions/recommendations: The UR signage and fencing are in excellent condition. There are no signs of animal burrows on the surface. No evidence of vegetation inside the fenced area or around the concrete monument pad. No issues or follow-up actions requived.

\section{F. CERTIFICATION}

I have conducted an inspection of CAU 91, Area 3 U-3fi Injection Well, in accordance with the procedures of the Post-Closure Permit (including the PostClosure Plan) as recorded on this checklist, attached shegts, field notes, photographs, and photograph logs.

Chief Inspector's Signature: Printed Name: Glenn Bickardson

\section{Date: \\ $9 / 23 / 08$}

Title: Task Manager

Attachments (check if attached):

$\square$ Field Notes

$\square$ Photos

$\square$ Maintenance records 
RCRA Post-Closure Report

Revision: 0

Date: December 2008

\section{CORRECTIVE ACTION UNIT 92 INSPECTION CHECKLISTS}


RCRA Post-Closure Report

Revision: 0

Date: December 2008

THIS PAGE INTENTIONALLY LEFT BLANK 
Inspection Requirements:

(1) Quarterly, or

(2) Rain Event of $>0.5$ inches in 24 hours

\section{POST-CLOSURE INSPECTION CHECKLIST}

\section{CAU 92: AREA 6 DECON POND FACILITY - CAS 06-05-02: Decontamination Pond (RCRA)}

\begin{tabular}{|c|c|}
\hline Inspection Date and Time: $1 / 28 / 08$ & Reason for Inspection: Precipitation Event $>0.5$ ir. \\
\hline Date of Last Post-Closure Inspection: $12 / 18 / 07$ & Reason for Last Post-Closure Inspection: Quarterly \\
\hline 127108 led & Quantity of Rainfall in that event: $\underset{-0.8}{.63}$ inches $\mathrm{SeCl}$ \\
\hline
\end{tabular}

Responsible Entity: NSTec Environmental Restoration, Nevada Test Site, Mercury, Nevada

Responsible Facility Owner: Thomas A. Thiele, Project Manager, Industrial Sites, Environmental Restoration Project

\begin{tabular}{|l|l|l|} 
Chief Inspector: Glenen Richardson & Title: Task Manager & Organization: Environmental Restoration \\
\hline Assistant Inspector: Dudley Emer & Title: Sr. Scientist & Organization: Environmental Restoration \\
\hline \hline
\end{tabular}

\section{A. GENERAL INSTRUCTIONS}

1. All checklist items must be completed, including detailed comments to document the results of the site inspection. The completed checklist is part of the field record of the inspection. Additional pages should be used as necessary to ensure that a complete record is made. Attach the additional pages and number all pages upon completion of the inspection.

2. Any checklist line item marked in a SHADED BOX must be fully explained or an appropriate reference to previous reports provided. The purpose of this requirement is to provide a written explanation of inspector's and the rationale for conclusions and recommendations. Explanations are to be placed on additional attachments and cross-referenced appropriately. Explanations, in addition to narrative, will take the form of sketches, measurements, and annotated site maps.

3. The site inspection is a walking inspection of the entire site. This includes the perimeter and sufficient transects to be able to inspect the entire surface and all features specifically described in this checklist.

4. A standard set of color photographs is required. In addition, all anomalous features or new features (such as changes in adjacent area land use) are to be photographed. A photograph log will be completed, and an entry will be made for each photograph taken.

5. Field notes taken to assist in completion of this checklist will become part of the inspection record. No form is specified for field notes; however, they must be legible and in sufficient detail to enable review by succeeding inspectors and the responsible agency.

6. This unit will be inspected quarterly, with a formal report provided to the Nevada Division of Environmental Protection annually. The annual report will include an executive summary; this inspection checklist with field notes, photographs, and photograph log; and conclusions and recommendations.

\begin{tabular}{|c|c|c|c|}
\hline B. PREPARATION (To be competed prior to site visit) & YES & NO & EXPLANATION (required if shaded box is checked) \\
\hline \multicolumn{4}{|l|}{ 1. Has the Post-Closure Permit been reviewed? } \\
\hline \multicolumn{4}{|l|}{ 2. Has the Post-Closure Permit application been reviewed? } \\
\hline \multicolumn{4}{|l|}{ 3. Has the Post-Closure Plan been reviewed? } \\
\hline \multicolumn{4}{|l|}{ 4. Have the site as-built plans and site base map been reviewed? } \\
\hline \multicolumn{4}{|l|}{ 5. Have the previous inspection reports been reviewed? } \\
\hline \multicolumn{4}{|l|}{ a. Were anomalies or trends detected on previous inspections? } \\
\hline \multicolumn{4}{|l|}{ b. Was maintenance performed? } \\
\hline $\begin{array}{l}\text { If maintenance was performed, has a copy of the } \\
\text { maintenance records been obtained? }\end{array}$ & & & \\
\hline \multicolumn{4}{|l|}{ 6. Have the site maintenance and repair records been reviewed? } \\
\hline $\begin{array}{l}\text { a. If so, has site repair resulted in a change from as-built } \\
\text { conditions? }\end{array}$ & & & NA \\
\hline $\begin{array}{l}\text { b. If yes (to } 6 a \text { ), are revised as-built plans available that reflect } \\
\text { repair changes? }\end{array}$ & & & NA \\
\hline
\end{tabular}


Inspection Requirements:

(1) Quarterly, or

(2) Rain Event of $>0.5$ inches in 24 hours

POST-CLOSURE INSPECTION CHECKLIST

CAU 92: AREA 6 DECON POND FACILITY - CAS 06-05-02: Decontamination Pond (RCRA)

\section{SITE INSPECTION PREPARATION}

Assemble the following, as needed, to conduct inspections:

a. Camera, film, and batteries

b. Keys to locks

c. Clipboard

d. Tape measure

e. Radio, pager, etc.

f. Previous Post-Closure Report, Inspection Checklists, repair records, and as-built plans

g. Other miscellaneous support equipment

\section{SITE INSPECTION}

1. Adjacent off-site features:

a. Are there any new activities or features on Yucca Lake that could potentially affect the site (e.g., activities that change the flow of surface water or are encroaching the unit)?

2. Fencing, gates, and signs:

a. Is there damage to or a break in the fence?

b. Have any fenceposts been damaged or their anchoring weakened?

c. Are any of the use restriction signs damaged or missing?

d. Are all use restriction signs legible?

e. How many use restriction signs need to be replaced?

f. Are any of the URMA signs damaged or missing?

g. Are all URMA signs legible?

h. How many URMA signs need to be replaced?

i. Is the gate intact and functional?

j. Does the gate show evidence of tampering or damage?

k. Was the gate locked?

1. Does the wave barrier require repair?

$\mathrm{m}$. Is there standing water within or at the fenceline?

If yes, what is the playa water elevation, as measured on the depth gauge attached to the fence perimeter?

n. Other?

3. Waste unit cover:

a. Is there evidence of settling?

b. Is there evidence of cracking?

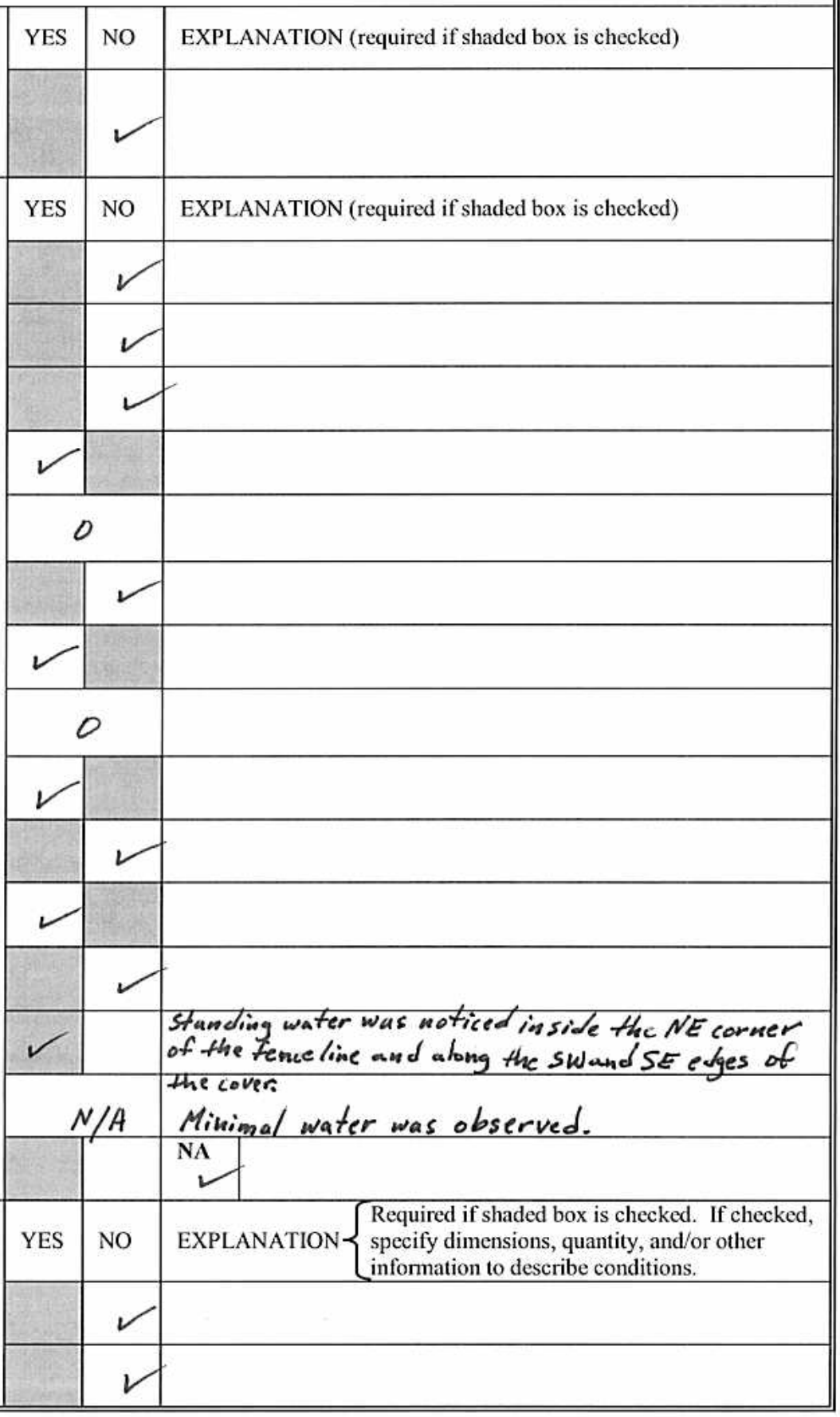


mspection requirements:

(1) Quarterly, or

(2) Rain Event of $>0.5$ inches in 24 hours

\section{POST-CLOSURE INSPECTION CHECKLIST}

\section{CAU 92: AREA 6 DECON POND FACILITY - CAS 06-05-02: Decontamination Pond (RCRA)}

3. Waste unit cover (continued):

c. Is there evidence of erosion (wind or water)?

d. Is there evidence of human intrusion onto the cover?

c. Is there evidence of large animal intrusion onto the cover?

f. Is there evidence of animal burrowing?

g. Is vegetation growing on the cover?

h. Other (including trash, debris, etc within fenced area)?

4. Subsidence survey markers:

a. Have any of the 5 subsidence survey markers been disturbed?

b. Do natural processes threaten the integrity of any subsidence survey marker?

c. Is there excessive vegetation around the subsidence survey markers?

d. Other?

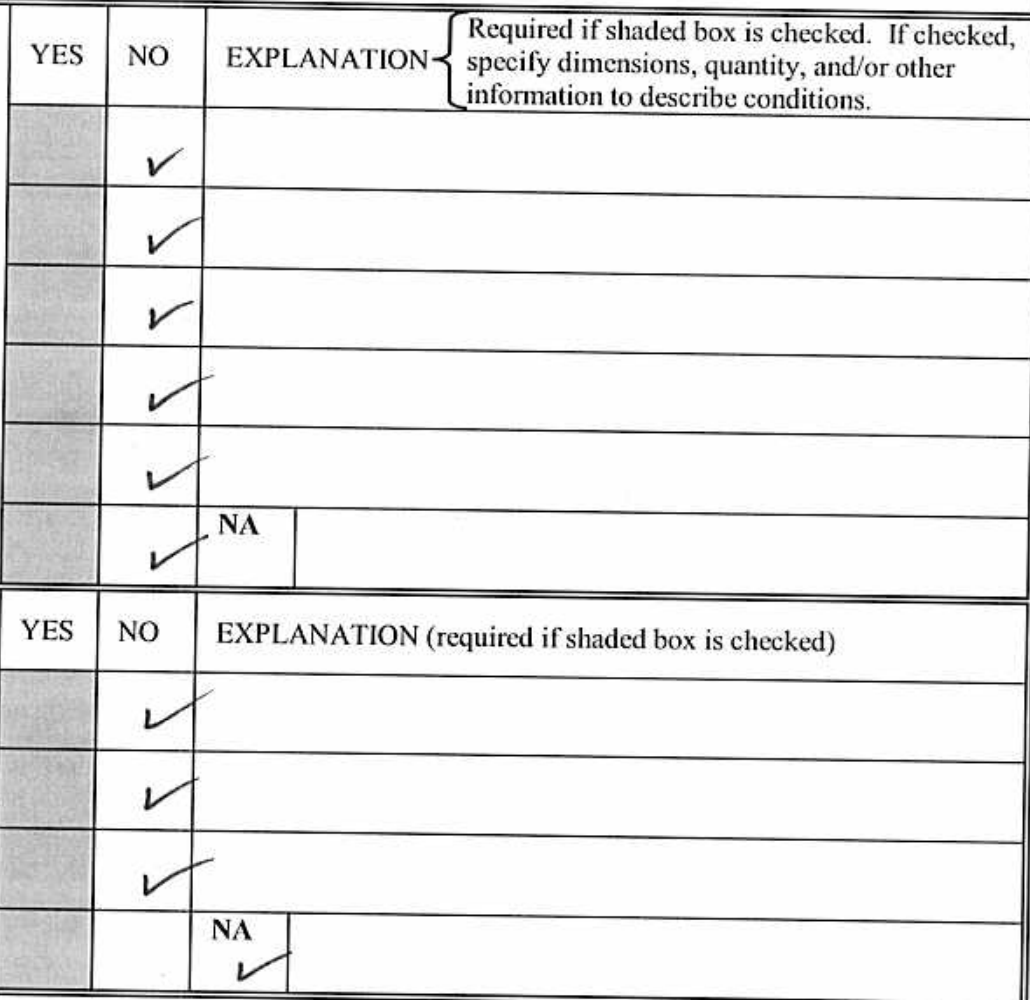

5. Photograph Instructions: A total of 8 photographs must be taken during each inspection of CAU 92 . Additional photographs may also be taken. The required photographs shall
be taken as follows:

- Four (4) from the center of the unit, one in each compass direction (i.e., N, S, E, W) and

- Four (4) of the unit from outside the fence, one in each compass direction.

6. Photograph Documentation:

a. Have all photographs been taken as required by the photograph instructions?

b. Has a photograph log been prepared?

c. How many photographs were taken?

d. Other?

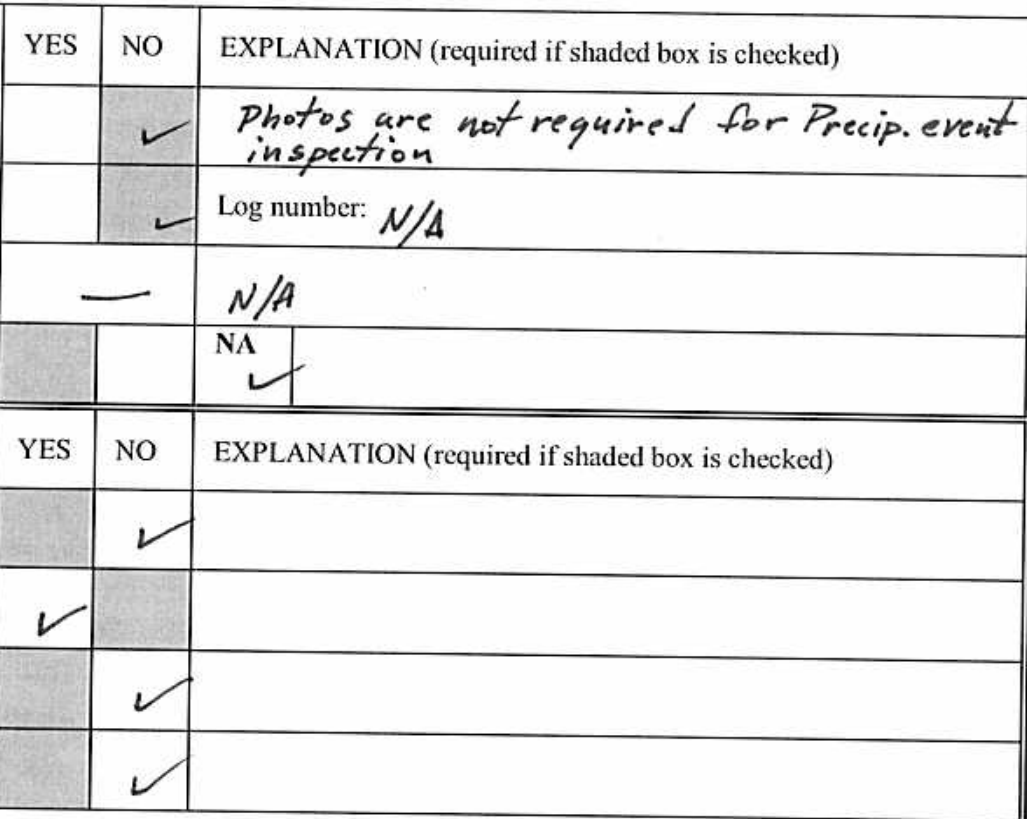

Date reported:

Person/Agency to whom report was made: 
Inspection Requirements:

(1) Quarterly, or

(2) Rain Event of $>0.5$ inches in 24 hours

\section{POST-CLOSURE INSPECTION CHECKLIST}

\section{CAU 92: AREA 6 DECON POND FACILITY - CAS 06-05-02: Decontamination Pond (RCRA)}

5. Field conclusions/recommendations: Noticed standing water inside the NE corner of the fenceline and along the SW and SE edges of the cover, but no standing water was observed on the actual cover. The $U R$ signs and wave barriers were not damaged and in good condition. The chain link fencing was intart and the sife was secured. No corrective actions are required.

\section{F. CERTIFICATION}

I have conducted an inspection of CAU 92, Area 6 Decon Pond Facility, in accordance with the procedures of the Post-Closure Permit (including the Post-Closure Plan) as recorded on this checklist, attached sheets, field notes, photographs, and photograph logs.

Chief Inspector's Signature:

Printed Name

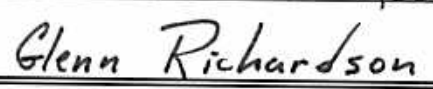

Date:

Title: Task Manager

Attachments (check if attached):

$\square$ Field Notes

$\square$ Photos

$\square$ Maintenance records 
Inspection Requirements:

(1) Quarterly, or

(2) Rain Event of $>0.5$ inches in 24 hours

\section{POST-CLOSURE INSPECTION CHECKLIST}

\section{CAU 92: AREA 6 DECON POND FACILITY - CAS 06-05-02: Decontamination Pond (RCRA)}

\begin{tabular}{|l|l||}
\hline \hline Inspection Date and Time: $3 / 26 / 08 \quad$ I/:40 AM & Reason for Inspection: Quarterly \\
\hline Date of Last Post-Closure Inspection: 1/28/08 & Reason for Last Post-Closure Inspection: Precipitation Even \\
\hline Date of Last Rain Event: $1 / 27 / 08$ & Quantity of Rainfall in that event: .63 inches \\
\hline
\end{tabular}

Responsible Entity: NSTec Environmental Restoration, Nevada Test Site, Mercury, Nevada

Responsible Facility Owner: Thomas A. Thiele, Project Manager, Industrial Sites, Environmental Restoration Project

\begin{tabular}{|l|l|l}
\hline Chief Inspector: Glenn Richardson & Title: Task Manager & Organization: Environmental Restoration \\
\hline Assistant Inspector: Mike Floyd & Title: Field Technical Lead & Organization: Environmental Restoration \\
\hline \hline
\end{tabular}

A. GENERAL INSTRUCTIONS

1. All checklist items must be completed, including detailed comments to document the results of the site inspection. The completed checklist is part of the field record of the inspection. Additional pages should be used as necessary to ensure that a complete record is made. Attach the additional pages and number all pages upon completion of the inspection.

2. Any checklist line item marked in a SHADED BOX must be fully explained or an appropriate reference to previous reports provided. The purpose of this requirement is to provide a written explanation of inspector's and the rationale for conclusions and recommendations. Explanations are to be placed on additional attachments and cross-referenced appropriately. Explanations, in addition to narrative, will take the form of sketches, measurements, and annotated site maps.

3. The site inspection is a walking inspection of the entire site. This includes the perimeter and sufficient transects to be able to inspect the entire surface and all features specifically described in this checklist.

4. A standard set of color photographs is required. In addition, all anomalous features or new features (such as changes in adjacent area land use) are to be photographed. A photograph log will be completed, and an entry will be made for each photograph taken.

5. Field notes taken to assist in completion of this checklist will become part of the inspection record. No form is specified for field notes; however, they must be legible and in sufficient detail to enable review by succeeding inspectors and the responsible agency.

6. This unit will be inspected quarterly, with a formal report provided to the Nevada Division of Environmental Protection annually. The annual report will include an executive summary; this inspection checklist with field notes, photographs, and photograph log; and conclusions and recommendations.

\begin{tabular}{|c|c|c|c|}
\hline B. PREPARATION (To be competed prior to site visit) & YES & NO & EXPLANATION (required if shaded box is checked) \\
\hline \multicolumn{4}{|l|}{ 1. Has the Post-Closure Permit been reviewed? } \\
\hline \multicolumn{4}{|l|}{ 2. Has the Post-Closure Permit application been reviewed? } \\
\hline \multicolumn{4}{|l|}{ 3. Has the Post-Closure Plan been reviewed? } \\
\hline \multicolumn{4}{|l|}{ 4. Have the site as-built plans and site base map been reviewed? } \\
\hline \multicolumn{4}{|l|}{ 5. Have the previous inspection reports been reviewed? } \\
\hline \multicolumn{4}{|l|}{ a. Were anomalies or trends detected on previous inspections? } \\
\hline \multicolumn{4}{|l|}{ b. Was maintenance performed? } \\
\hline $\begin{array}{l}\text { If maintenance was performed, has a copy of the } \\
\text { maintenance records been obtained? }\end{array}$ & & & NA \\
\hline \multicolumn{4}{|l|}{ 6. Have the site maintenance and repair records been reviewed? } \\
\hline $\begin{array}{l}\text { a. If so, has site repair resulted in a change from as-built } \\
\text { conditions? }\end{array}$ & & & NA \\
\hline $\begin{array}{l}\text { b. If yes (to } 6 \mathrm{a} \text { ), are revised as-built plans available that reflect } \\
\text { repair changes? }\end{array}$ & & & NA \\
\hline
\end{tabular}




\section{POST-CLOSURE INSPECTION CHECKLIST}

\section{CAU 92: AREA 6 DECON POND FACILITY - CAS 06-05-02: Decontamination Pond (RCRA)}

\section{SITE INSPECTION PREPARATION}

Assemble the following, as needed, to conduct inspections:

a. Camera, film, and batteries

b. Keys to locks

c. Clipboard

d. Tape measure

e. Radio, pager, etc.

f. Previous Post-Closure Report, Inspection Checklists, repair records, and as-built plans

g. Other miscellaneous support equipment

\section{SITE INSPECTION}

1. Adjacent off-site features:

a. Are there any new activities or features on Yucca Lake that could potentially affect the site (e.g., activities that change the flow of surface water or are encroaching the unit)?

2. Fencing, gates, and signs:

a. Is there damage to or a break in the fence?

b. Have any fenceposts been damaged or their anchoring weakened?

c. Are any of the use restriction signs damaged or missing?

d. Are all use restriction signs legible?

e. How many use restriction signs need to be replaced?

f. Are any of the URMA signs damaged or missing?

g. Are all URMA signs legible?

h. How many URMA signs need to be replaced?

i. Is the gate intact and functional?

j. Does the gate show evidence of tampering or damage?

k. Was the gate locked?

1. Does the wave barrier require repair?

$\mathrm{m}$. Is there standing water within or at the fenceline?

If yes, what is the playa water elevation, as measured on the depth gauge attached to the fence perimeter?

n. Other?

3. Waste unit cover:
a. Is there evidence of settling?
b. Is there evidence of cracking?

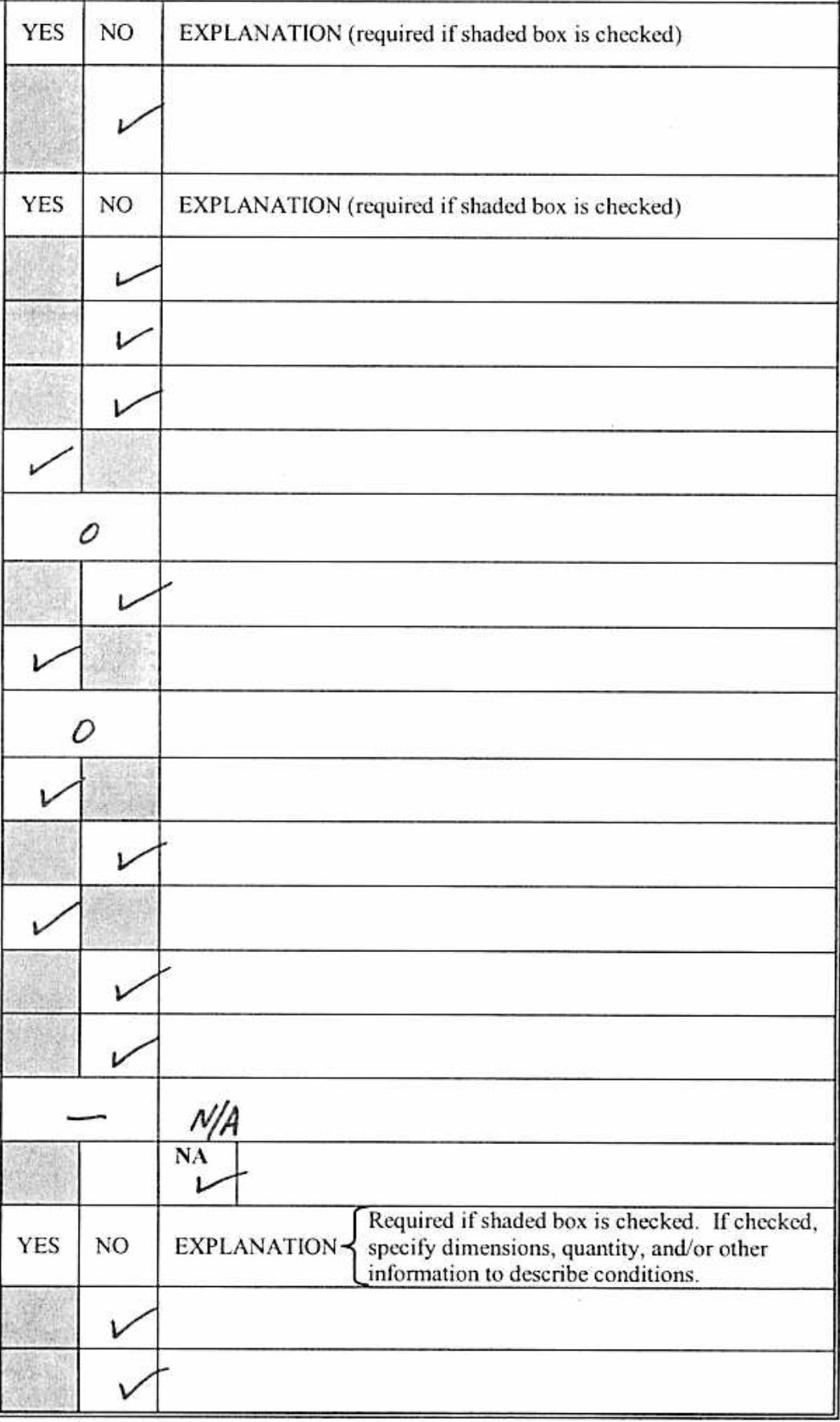


Inspection Requirements:

(1) Quarterly, or

(2) Rain Event of $>0.5$ inches in 24 hours

\section{POST-CLOSURE INSPECTION CHECKLIST}

\section{CAU 92: AREA 6 DECON POND FACILITY - CAS 06-05-02: Decontamination Pond (RCRA)}

3. Waste unit cover (continued):

c. Is there evidence of erosion (wind or water)?

d. Is there evidence of human intrusion onto the cover?

e. Is there evidence of large animal intrusion onto the cover?

f. Is there evidence of animal burrowing?

g. Is vegetation growing on the cover?

h. Other (including trash, debris, etc within fenced area)?

\begin{tabular}{|l|l|l|l|}
\hline YES & NO & EXPLANATION $\left\{\begin{array}{l}\text { Required if shaded box is checked. If checked, } \\
\text { specify dimensions, quantity, and/or other } \\
\text { information to describe conditions. }\end{array}\right.$ \\
\hline & & & \\
\hline & & $\begin{array}{l}\text { There are small amounts of vegetation sprouting } \\
\text { on and around the perimeter of the cover. }\end{array}$ \\
\hline YES & NO & EXPLANATION (required if shaded box is checked) \\
\hline & & \\
\hline & & \\
\hline
\end{tabular}

5. Photograph Instructions:

A total of 8 photographs must be taken during each inspection of CAU 92. Additional photographs may also be taken. The required photographs shall be taken as follows:

- Four (4) from the center of the unit, one in each compass direction (i.e., N, S, E, W) and

- Four (4) of the unit from outside the fence, one in each compass direction.

6. Photograph Documentation:

a. Have all photographs been taken as required by the photograph instructions?

b. Has a photograph log been prepared?

c. How many photographs were taken?

d. Other?

\section{E. FIELD CONCLUSIONS}

1. Are more frequent inspections required?

2. Are existing maintenance/repair actions satisfactory?

3. Is other maintenance/repair necessary?

4. Is there an imminent hazard to the integrity of the site? (Immediate report required)

\begin{tabular}{|c|c|c|}
\hline YES & NO & EXPLANATION (required if shaded box is checked) \\
\hline$\checkmark$ & 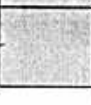 & $\begin{array}{l}\text { Log number: An electronic } \log \text { is availatle on the } \\
\text { ER shared drive, ander CA4 } 92\end{array}$ \\
\hline \multicolumn{3}{|c|}{8} \\
\hline & & NA \\
\hline YES & NO & EXPLANATION (required if shaded box is checked) \\
\hline & $\checkmark$ & \\
\hline$\checkmark$ & & $\begin{array}{l}\text { Vegetation removal and herbicide application } \\
\text { is necessary. }\end{array}$ \\
\hline & $\checkmark$ & \\
\hline
\end{tabular}

Date reported:

Person/Agency to whom report was made: 


\section{Inspection Requirements:}

(1) Quarterly, or

(2) Rain Event of $>0.5$ inches in 24 hours

\section{POST-CLOSURE INSPECTION CHECKLIST}

\section{CAU 92: AREA 6 DECON POND FACILITY - CAS 06-05-02: Decontamination Pond (RCRA)}

5. Field conclusions/recommendations: The signage, fencing, and wave barriers were in excellent condition. There was no evidence of animal burrowing. Noticed small amount of vegefation sprouting in different areas on and around the perimeter of the cover. Vegetation removal will occur within 60 days. Also, an herbicide application will be used to prevent vegetation growth during
the next few months.

\section{F. CERTIFICATION}

I have conducted an inspection of CAU 92, Area 6 Decon Pond Facility, in accordance with the procedures of the Post-Closure Permit (including the Post-Closure Plan) as recorded on this checklist, attached sheets, field notes, photographs, and photograph logs.

Chief Inspector's Signature:

Attachments (check if attached):

$\square$ Field Notes

$\square$ Photos

$\square$ Maintenance records 


\section{POST-CLOSURE INSPECTION CHECKLIST}

\section{CAU 92: AREA 6 DECON POND FACILITY - CAS 06-05-02: Decontamination Pond (RCRA)}

\begin{tabular}{||l|l||}
\hline Inspection Date and Time: $6 / 17 / 08 / 30$ & Reason for Inspection: Qu ARterc4 \\
\hline Date of Last Post-Closure Inspection: $3 / 26 / 08$ & Reason for Last Post-Closure Inspection: QuRR terels \\
\hline Date of Last Rain Event: & Quantity of Rainfall in that event: 63 inches \\
\hline
\end{tabular}

Responsible Entity: NSTec Environmental Restoration, Nevada Test Site, Mercury, Nevada

Responsible Facility Owner: Thomas A. Thiele, Project Manager, Industrial Sites, Environmental Restoration Project

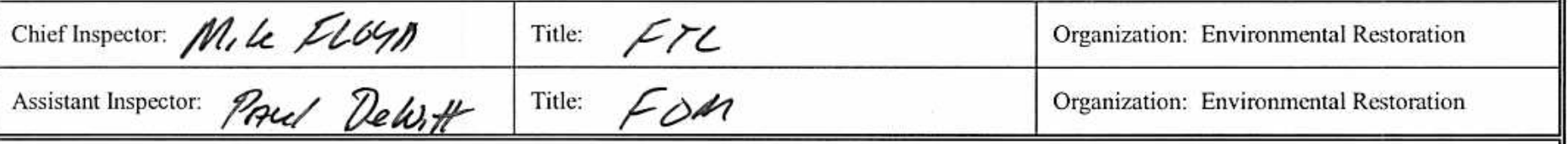

A. GENERAL INSTRUCTIONS

1. All checklist items must be completed, including detailed comments to document the results of the site inspection. The completed checklist is part of the field record of the inspection. Additional pages should be used as necessary to ensure that a complete record is made. Attach the additional pages and number all pages upon completion of the inspection.

2. Any checklist line item marked in a SHADED BOX must be fully explained or an appropriate reference to previous reports provided. The purpose of this requirement is to provide a written explanation of inspector's and the rationale for conclusions and recommendations. Explanations are to be placed on additional attachments and cross-referenced appropriately. Explanations, in addition to narrative, will take the form of sketches, measurements, and annotated site maps.

3. The site inspection is a walking inspection of the entire site. This includes the perimeter and sufficient transects to be able to inspect the entire surface and all features specifically described in this checklist.

4. A standard set of color photographs is required. In addition, all anomalous features or new features (such as changes in adjacent area land use) are to be photographed. A photograph log will be completed, and an entry will be made for each photograph taken.

5. Field notes taken to assist in completion of this checklist will become part of the inspection record. No form is specified for field notes; however, they must be legible and in sufficient detail to enable review by succeeding inspectors and the responsible agency.

6. This unit will be inspected quarterly, with a formal report provided to the Nevada Division of Environmental Protection annually. The annual report will include an executive summary; this inspection checklist with field notes, photographs, and photograph log; and conclusions and recommendations.

\begin{tabular}{|c|c|c|c|}
\hline B. PREPARATION (To be competed prior to site visit) & YES & NO & EXPLANATION (required if shaded box is checked) \\
\hline \multicolumn{4}{|l|}{ 1. Has the Post-Closure Permit been reviewed? } \\
\hline \multicolumn{4}{|l|}{ 2. Has the Post-Closure Permit application been reviewed? } \\
\hline \multicolumn{4}{|l|}{ 3. Has the Post-Closure Plan been reviewed? } \\
\hline \multicolumn{4}{|l|}{ 4. Have the site as-built plans and site base map been reviewed? } \\
\hline \multicolumn{4}{|l|}{ 5. Have the previous inspection reports been reviewed? } \\
\hline \multicolumn{4}{|l|}{ a. Were anomalies or trends detected on previous inspections? } \\
\hline b. Was maintenance performed? & & & $\begin{array}{l}\text { Uegitatron Remocel PRoll to Lespection } \\
\text { \&. } 2 \text { con }\end{array}$ \\
\hline $\begin{array}{l}\text { If maintenance was performed, has a copy of the } \\
\text { maintenance records been obtained? }\end{array}$ & & & NA \\
\hline \multicolumn{4}{|l|}{ 6. Have the site maintenance and repair records been reviewed? } \\
\hline $\begin{array}{l}\text { a. If so, has site repair resulted in a change from as-built } \\
\text { conditions? }\end{array}$ & & & \\
\hline $\begin{array}{l}\text { b. If yes (to } 6 \mathrm{a} \text { ), are revised as-built plans available that reflect } \\
\text { repair changes? }\end{array}$ & & & Ny \\
\hline
\end{tabular}


Inspection Requirements:

(1) Quarterly, or
(2) Rain Event of $>0.5$ inches in 24 hours

POST-CLOSURE INSPECTION CHECKLIST

CAU 92: AREA 6 DECON POND FACILITY - CAS 06-05-02: Decontamination Pond (RCRA)

\section{SITE INSPECTION PREPARATION}

Assemble the following, as needed, to conduct inspections:

a. Camera, film, and batteries

b. Keys to locks

c. Clipboard

d. Tape measure

e. Radio, pager, etc.

f. Previous Post-Closure Report, Inspection Checklists, repair records, and as-built plans

g. Other miscellaneous support equipment

\section{SITE INSPECTION}

1. Adjacent off-site features:

a. Are there any new activities or features on Yucca Lake that could potentially affect the site (e.g., activities that change the flow of surface water or are encroaching the unit)?

2. Fencing, gates, and signs:

a. Is there damage to or a break in the fence?

b. Have any fenceposts been damaged or their anchoring weakened?

c. Are any of the use restriction signs damaged or missing?

d. Are all use restriction signs legible?

e. How many use restriction signs need to be replaced?

f. Are any of the URMA signs damaged or missing?

g. Are all URMA signs legible?

h. How many URMA signs need to be replaced?

i. Is the gate intact and functional?

j. Does the gate show evidence of tampering or damage?

k. Was the gate locked?

1. Does the wave barrier require repair?

$\mathrm{m}$. Is there standing water within or at the fenceline?

If yes, what is the playa water elevation, as measured on the depth gauge attached to the fence perimeter?

n. Other?

3. Waste unit cover:
a. Is there evidence of settling?
b. Is there evidence of cracking?

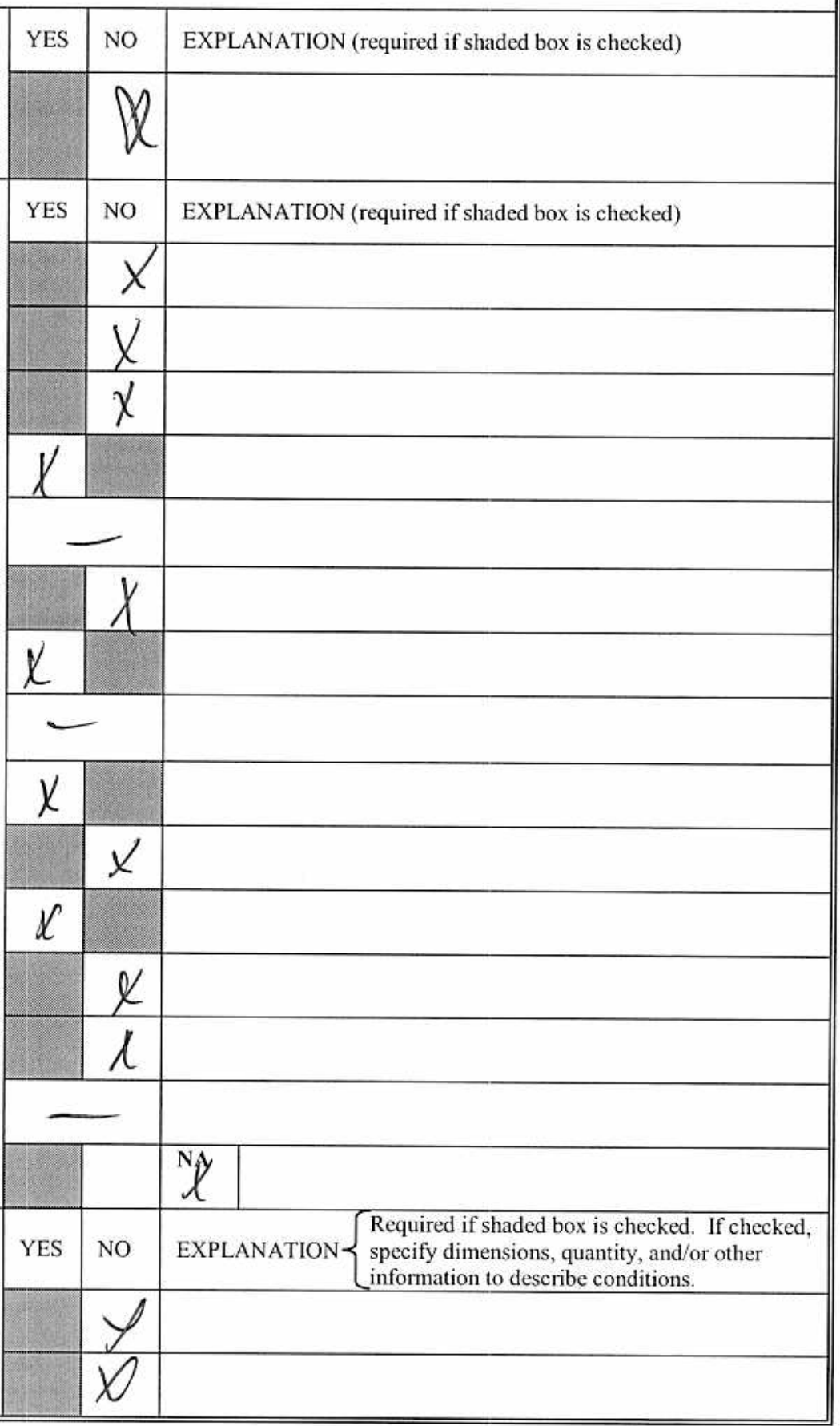


Inspection Requirements:

(1) Quarterly, or

(2) Rain Event of $>0.5$ inches in 24 hours

\section{POST-CLOSURE INSPECTION CHECKLIST}

CAU 92: AREA 6 DECON POND FACILITY - CAS 06-05-02: Decontamination Pond (RCRA)

3. Waste unit cover (continued):

c. Is there evidence of erosion (wind or water)?

d. Is there evidence of human intrusion onto the cover?

e. Is there evidence of large animal intrusion onto the cover?

f. Is there evidence of animal burrowing?

g. Is vegetation growing on the cover?

h. Other (including trash, debris, etc within fenced area)?

4. Subsidence survey markers:

a. Have any of the 5 subsidence survey markers been disturbed?

b. Do natural processes threaten the integrity of any subsidence survey marker?

c. Is there excessive vegetation around the subsidence survey markers?

d. Other?

\begin{tabular}{|c|c|c|}
\hline YES & NO & EXPLANATION $\left\{\begin{array}{l}\text { Required if shaded box is checked. If checked, } \\
\text { specify dimensions, quantity, and/or other } \\
\text { information to describe conditions. }\end{array}\right.$ \\
\hline & V & \\
\hline & $x$ & \\
\hline & $X$ & \\
\hline & $x$ & \\
\hline$\chi$ & & $\begin{array}{l}\text { Uexy lite Vas. As a BMD Recomend } \\
\text { 2r Be Remeved }\end{array}$ \\
\hline & K & \begin{tabular}{l|l} 
NA &
\end{tabular} \\
\hline YES & NO & EXPLANATION (required if shaded box is checked) \\
\hline & $X$ & \\
\hline & $\chi$ & - \\
\hline & $x$ & \\
\hline & & NA \\
\hline
\end{tabular}

5. Photograph Instructions:

A total of 8 photographs must be taken during each inspection of CAU 92. Additional photographs may also be taken. The required photographs shall be taken as follows:

- Four (4) from the center of the unit, one in each compass direction (i.e., N, S, E, W) and

- Four (4) of the unit from outside the fence, one in each compass direction.

6. Photograph Documentation:

a. Have all photographs been taken as required by the photograph instructions?

b. Has a photograph log been prepared?

c. How many photographs were taken?

d. Other?

\section{E. FIELD CONCLUSIONS}

1. Are more frequent inspections required?

2. Are existing maintenance/repair actions satisfactory?

3. Is other maintenance/repair necessary?

4. Is there an imminent hazard to the integrity of the site? (Immediate report required)

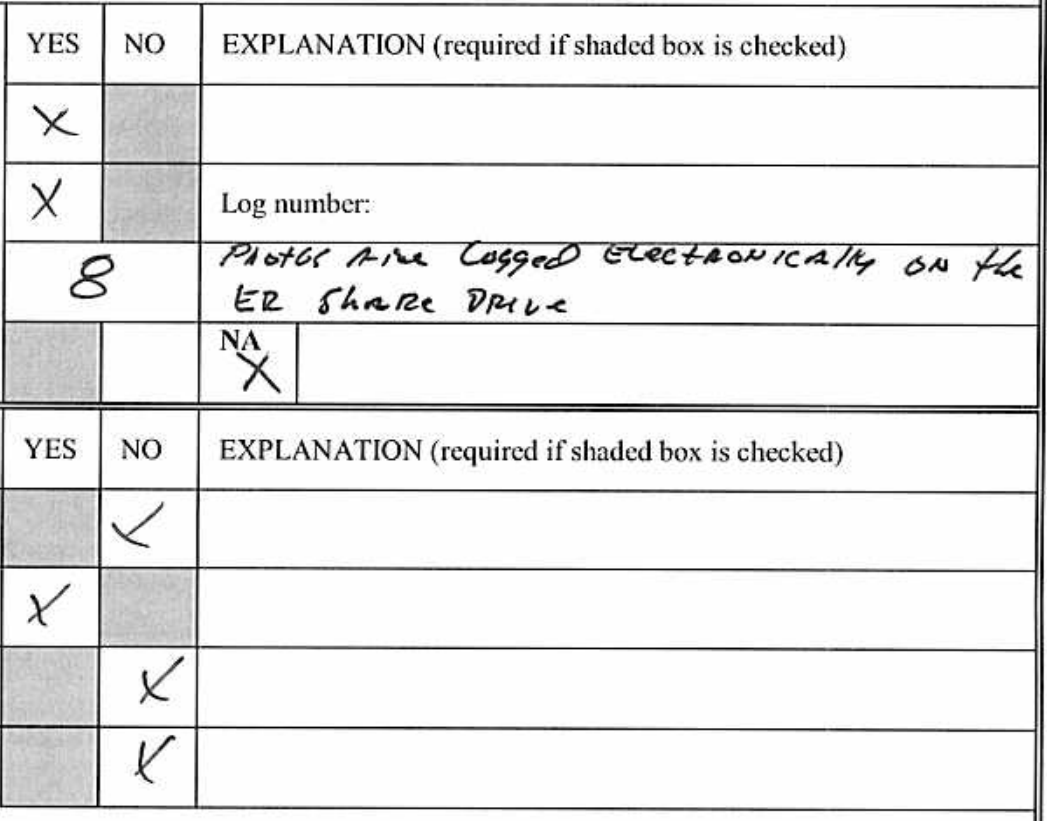

Date reported:

Person/Agency to whom report was made: 
Inspection Requirements:

(1) Quarterly, or

(2) Rain Event of $>0.5$ inches in 24 hours

POST-CLOSURE INSPECTION CHECKLIST

CAU 92: AREA 6 DECON POND FACILITY - CAS 06-05-02: Decontamination Pond (RCRA)

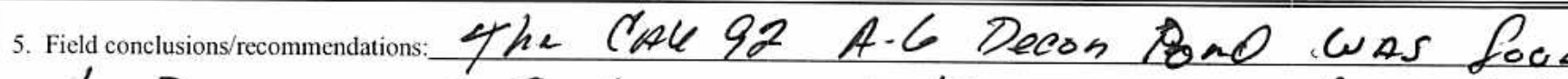

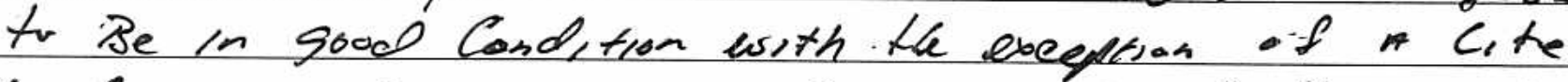

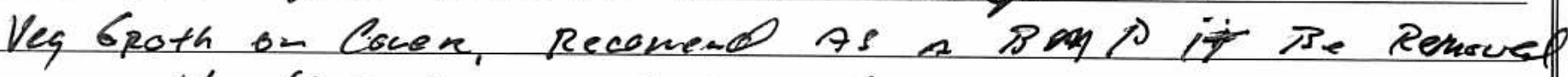
the UR singe nl Be updated to currant gondtace

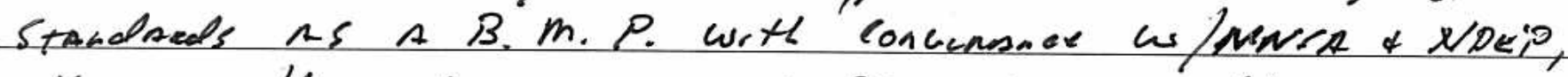

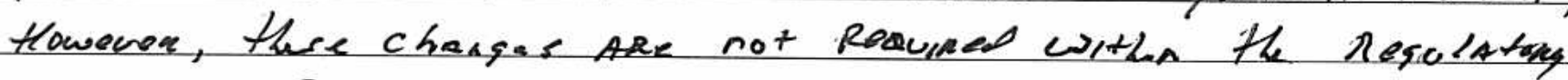
conpleneer person

F. CERTIFICATION

I have conducted an inspection of CAU 92, Area 6 Decon Pond Facility, in accordance with the procedures of the Post-Closure Permit (including the Post-Closure Plan) as recorded on this checklist gracgedgheets, field notes, photographs, and photograph logs.

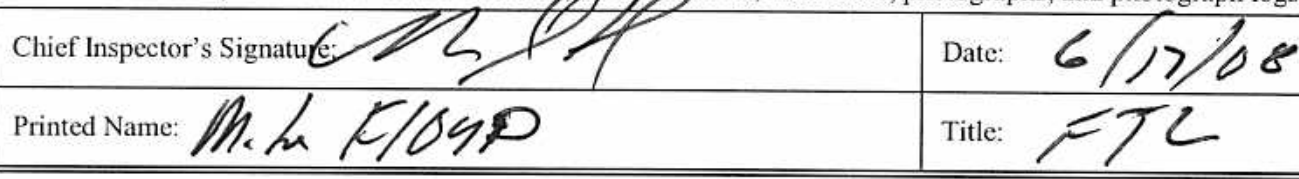

Attachments (check if attached):

$\square$ Field Notes

Photos

Maintenance records

Page 4 of 4 


\section{POST-CLOSURE INSPECTION CHECKLIST}

\section{CAU 92: AREA 6 DECON POND FACILITY - CAS 06-05-02: Decontamination Pond (RCRA)}

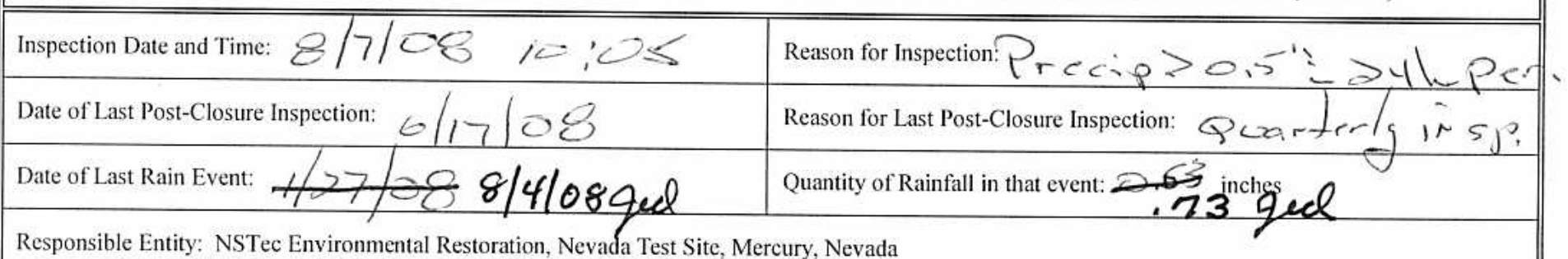

Responsible Facility Owner: Thomas A. Thiele, Project Manager, Industrial Sites, Environmental Restoration Project

\begin{tabular}{|c|c|c|}
\hline 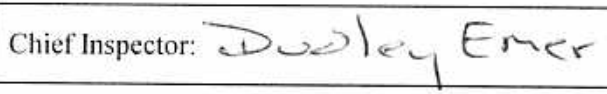 & Title: $S_{r} S_{1<2}, t$ & Organization: Environmental Restoration \\
\hline Assistant Inspector: & Title: & Organization: Environmental Restoration \\
\hline
\end{tabular}

\section{A. GENERAL INSTRUCTIONS}

1. All checklist items must be completed, including detailed comments to document the results of the site inspection. The completed checklist is part of the field record of the inspection. Additional pages should be used as necessary to ensure that a complete record is made. Attach the additional pages and number all pages upon completion of the inspection.

2. Any checklist line item marked in a SHADED BOX must be fully explained or an appropriate reference to previous reports provided. The purpose of this requirement is to provide a written explanation of inspector's and the rationale for conclusions and recommendations. Explanations are to be placed on additional attachments and cross-referenced appropriately. Explanations, in addition to narrative, will take the form of sketches, measurements, and annotated site maps.

3. The site inspection is a walking inspection of the entire site. This includes the perimeter and sufficient transects to be able to inspect the entire surface and all features specifically described in this checklist.

4. A standard set of color photographs is required. In addition, all anomalous features or new features (such as changes in adjacent area land use) are to be photographed. A photograph log will be completed, and an entry will be made for each photograph taken.

5. Field notes taken to assist in completion of this checklist will become part of the inspection record. No form is specified for field notes; however, they must be legible and in sufficient detail to enable review by succeeding inspectors and the responsible agency.

6. This unit will be inspected quarterly, with a formal report provided to the Nevada Division of Environmental Protection annually. The annual report will include an executive summary; this inspection checklist with field notes, photographs, and photograph log; and conclusions and recommendations.

B. PREPARATION (To be competed prior to site visit)

1. Has the Post-Closure Permit been reviewed?

2. Has the Post-Closure Permit application been reviewed?

3. Has the Post-Closure Plan been reviewed?

4. Have the site as-built plans and site base map been reviewed?

5. Have the previous inspection reports been reviewed?

a. Were anomalies or trends detected on previous inspections?

b. Was maintenance performed?

If maintenance was performed, has a copy of the maintenance records been obtained?

6. Have the site maintenance and repair records been reviewed?

a. If so, has site repair resulted in a change from as-built conditions?

b. If yes (to 6a), are revised as-built plans available that reflect repair changes?

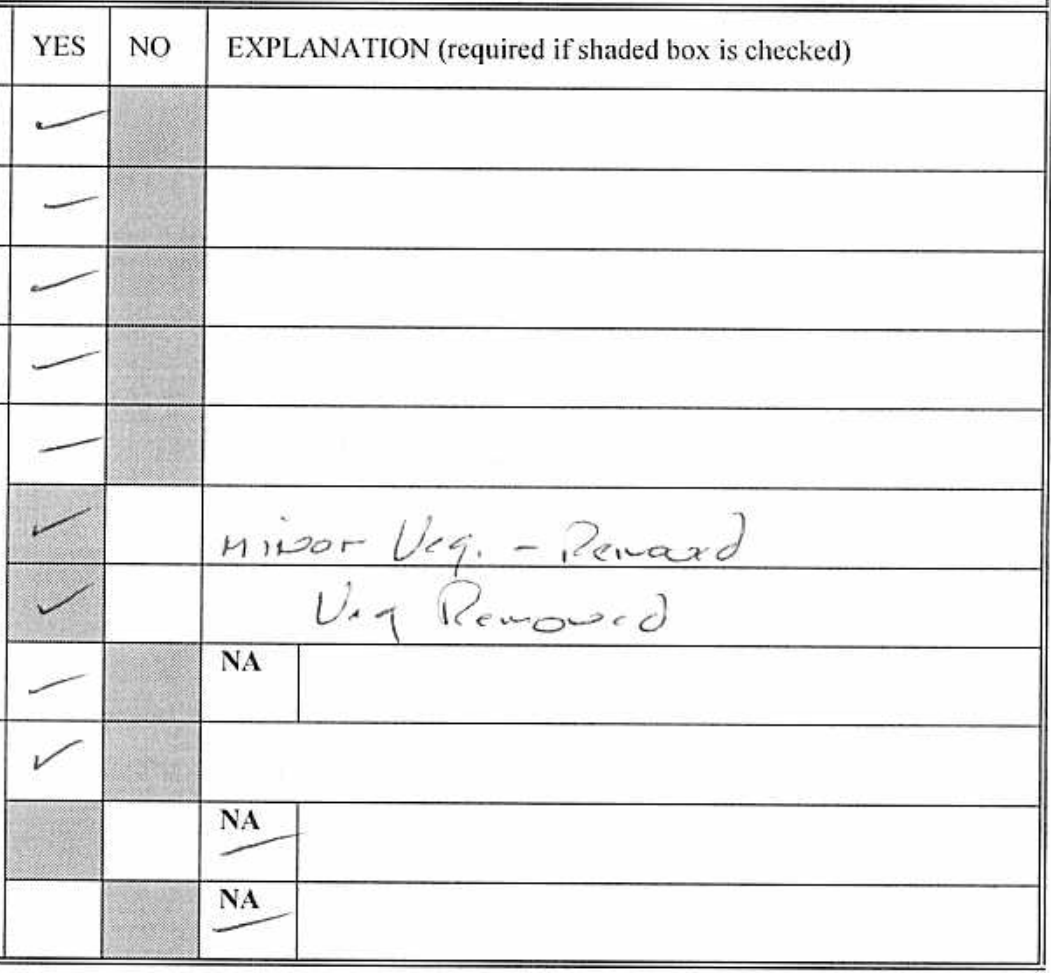


Inspection Requirements:

(1) Quarterly, or

(2) Rain Event of $>0.5$ inches in 24 hours

\section{POST-CLOSURE INSPECTION CHECKLIST}

\section{CAU 92: AREA 6 DECON POND FACILITY - CAS 06-05-02: Decontamination Pond (RCRA)}

\section{SITE INSPECTION PREPARATION}

Assemble the following, as needed, to conduct inspections:

a. Camera, film, and batteries

b. Keys to locks

c. Clipboard

d. Tape measure

e. Radio, pager, etc.

f. Previous Post-Closure Report, Inspection Checklists, repair records, and as-built plans

g. Other miscellaneous support equipment

\section{SITE INSPECTION}

1. Adjacent off-site features:

a. Are there any new activities or features on Yucca Lake that could potentially affect the site (e.g., activities that change the flow of surface water or are encroaching the unit)?

2. Fencing, gates, and signs:

a. Is there damage to or a break in the fence?

b. Have any fenceposts been damaged or their anchoring weakened?

c. Are any of the use restriction signs damaged or missing?

d. Are all use restriction signs legible?

e. How many use restriction signs need to be replaced?

f. Are any of the URMA signs damaged or missing?

g. Are all URMA signs legible?

h. How many URMA signs need to be replaced?

i. Is the gate intact and functional?

j. Does the gate show evidence of tampering or damage?

k. Was the gate locked?

1. Does the wave barrier require repair?

$\mathrm{m}$. Is there standing water within or at the fenceline?

If yes, what is the playa water elevation, as measured on the depth gauge attached to the fence perimeter?

n. Other?

3. Waste unit cover:

a. Is there evidence of settling?

b. Is there evidence of cracking?

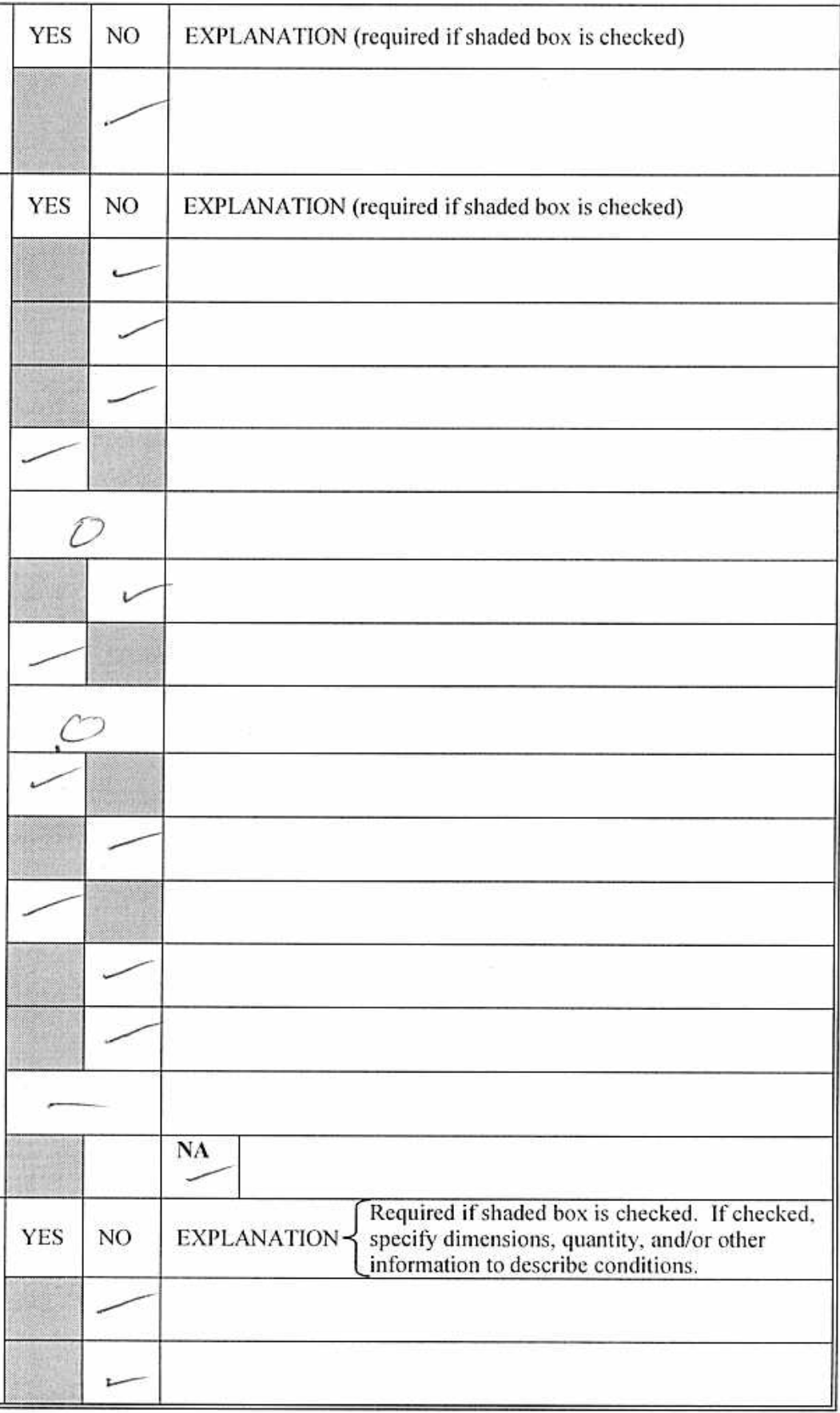


Inspection Requirements:

(1) Quarterly, or

(2) Rain Event of $>0.5$ inches in 24 hours

\section{POST-CLOSURE INSPECTION CHECKLIST}

\section{CAU 92: AREA 6 DECON POND FACILITY - CAS 06-05-02: Decontamination Pond (RCRA)}

3. Waste unit cover (continued):

c. Is there evidence of erosion (wind or water)?

d. Is there evidence of human intrusion onto the cover?

e. Is there evidence of large animal intrusion onto the cover?

f. Is there evidence of animal burrowing?

g. Is vegetation growing on the cover?

h. Other (including trash, debris, etc within fenced area)?

4. Subsidence survey markers:

a. Have any of the 5 subsidence survey markers been disturbed?

b. Do natural processes threaten the integrity of any subsidence survey marker?

c. Is there excessive vegetation around the subsidence survey markers?

d. Other?

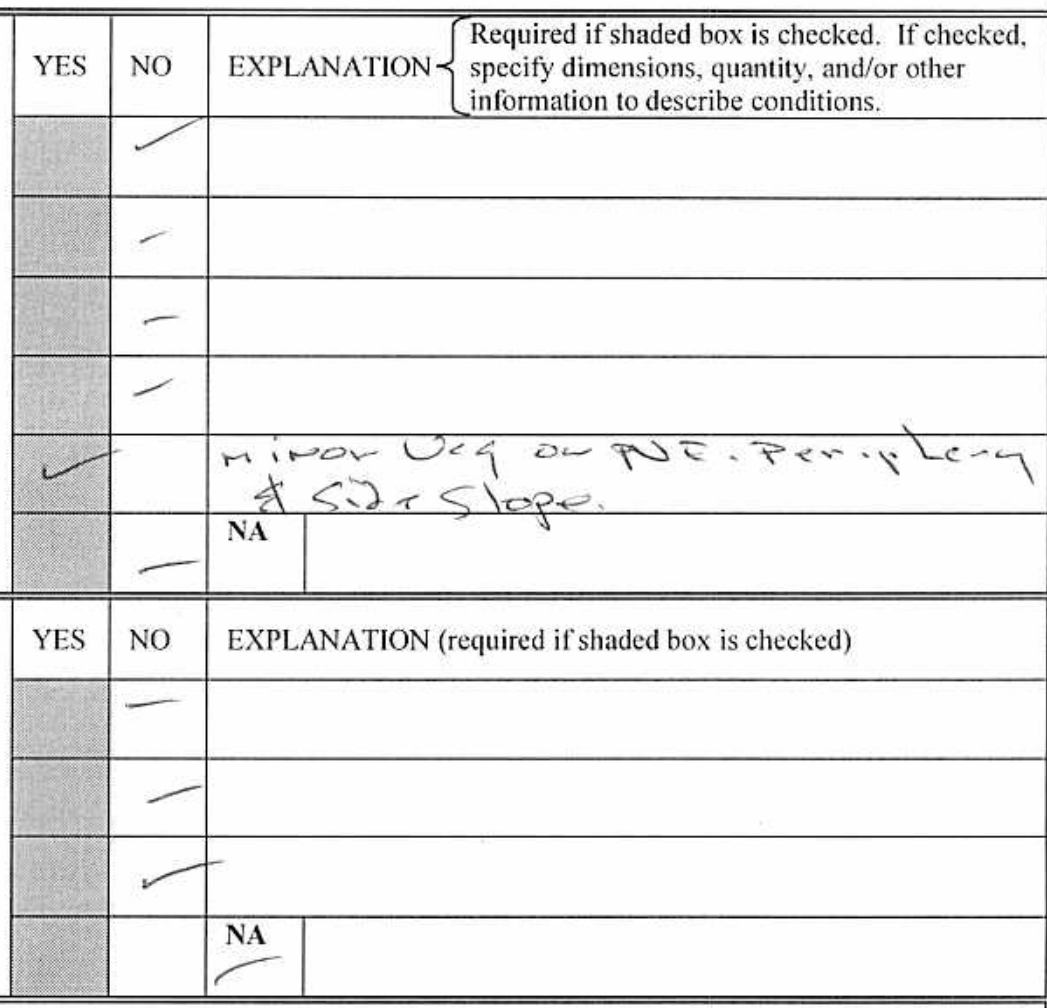

5. Photograph Instructions:

A total of 8 photographs must be taken during each inspection of CAU 92. Additional photographs may also be taken. The required photographs shall be taken as follows:

- Four (4) from the center of the unit, one in each compass direction (i.e., N, S, E, W) and

- Four (4) of the unit from outside the fence, one in each compass direction.

6. Photograph Documentation:

a. Have all photographs been taken as required by the photograph instructions?

b. Has a photograph log been prepared?

c. How many photographs were taken?

d. Other?

E. FIELD CONCLUSIONS

1. Are more frequent inspections required?

2. Are existing maintenance/repair actions satisfactory?

3. Is other maintenance/repair necessary?

4. Is there an imminent hazard to the integrity of the site? (Immediate report required)

\begin{tabular}{|l|l|l|}
\hline YES & NO & EXPLANATION (required if shaded box is checked) \\
\hline & & \\
\hline & & Log number: - \\
\hline YES & NO & EXPLANATION (required if shaded box is checked) \\
\hline & & \\
\hline
\end{tabular}

Date reported:

Person/Agency to whom report was made: 
Inspection Requirements:

(1) Quarterly, or

(2) Rain Event of $>0.5$ inches in 24 hours

\section{POST-CLOSURE INSPECTION CHECKLIST}

CAU 92: AREA 6 DECON POND FACILITY - CAS 06-05-02: Decontamination Pond (RCRA)

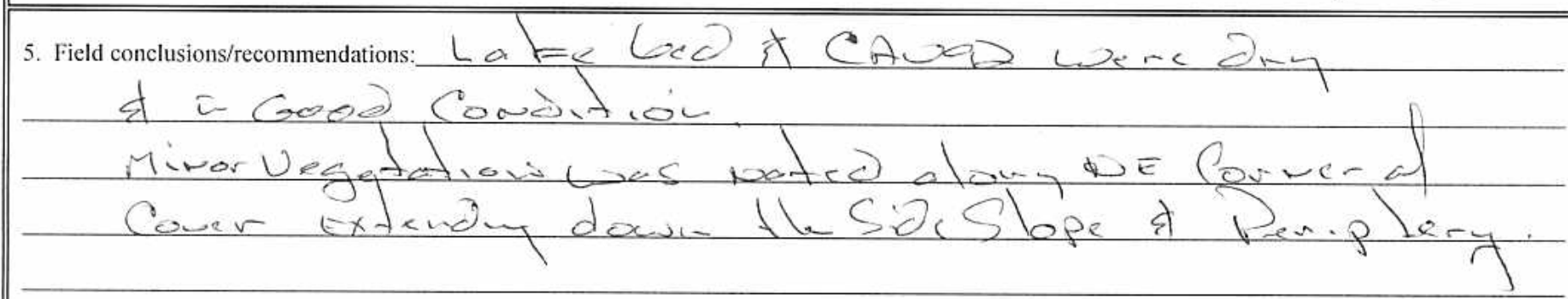

\section{F. CERTIFICATION}

I have conducted an inspection of CAU 92, Area 6 Decon Pond Facility, in accordance with the procedures of the Post-Closure Permit (including the Post-Closure Plan) as recorded on this checklist, attached sheets, field notes, photographs, and photograph logs.

Chief Inspector's Signature: I

Attachments (check if attached):

$\square$ Field Notes

$\square$ Photos

Maintenance records 
Inspection Requirements:

(1) Quarterly, or

(2) Rain Event of $>0.5$ inches in 24 hours

\section{POST-CLOSURE INSPECTION CHECKLIST}

\section{CAU 92: AREA 6 DECON POND FACILITY - CAS 06-05-02: Decontamination Pond (RCRA)}

\begin{tabular}{|l|l|}
\hline \hline Inspection Date and Time: $9 / 23 / 08 \quad$ // 30AM & Reason for Inspection: Quarterly \\
\hline Date of Last Post-Closure Inspection: $8 / 7 / 08$ & Reason for Last Post-Closure Inspection: Precipitation Event \\
\hline Date of Last Rain Event: $\quad 8 / 4 / 08$ & Quantity of Rainfall in that event: .73 inches \\
\hline S3
\end{tabular}

Responsible Entity: NSTec Environmental Restoration, Nevada Test Site, Mercury, Nevada

Responsible Facility Owner: Thomas A. Thiele, Project Manager, Industrial Sites, Environmental Restoration Project

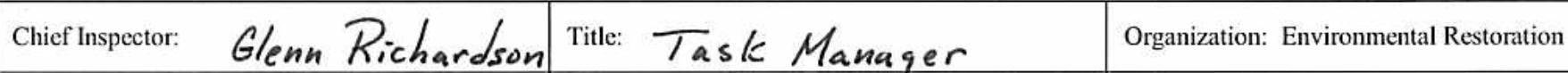

Assistant Inspector: Robert Green Title: Field Technical Lead Organization: Environmental Restoration

\section{A. GENERAL INSTRUCTIONS}

1. All checklist items must be completed, including detailed comments to document the results of the site inspection. The completed checklist is part of the field record of the inspection. Additional pages should be used as necessary to ensure that a complete record is made. Attach the additional pages and number all pages upon completion of the inspection.

2. Any checklist line item marked in a SHADED BOX must be fully explained or an appropriate reference to previous reports provided. The purpose of this requirement is to provide a written explanation of inspector's and the rationale for conclusions and recommendations. Explanations are to be placed on additional attachments and cross-referenced appropriately. Explanations, in addition to narrative, will take the form of sketches, measurements, and annotated site maps.

3. The site inspection is a walking inspection of the entire site. This includes the perimeter and sufficient transects to be able to inspect the entire surface and all features specifically described in this checklist.

4. A standard set of color photographs is required. In addition, all anomalous features or new features (such as changes in adjacent area land use) are to be photographed. A photograph log will be completed, and an entry will be made for each photograph taken.

5. Field notes taken to assist in completion of this checklist will become part of the inspection record. No form is specified for field notes; however, they must be legible and in sufficient detail to enable review by succeeding inspectors and the responsible agency.

6. This unit will be inspected quarterly, with a formal report provided to the Nevada Division of Environmental Protection annually. The annual report will include an executive summary; this inspection checklist with field notes, photographs, and photograph $\log$; and conclusions and recommendations.

\begin{tabular}{|c|c|c|c|c|}
\hline B. PREPARATION (To be competed prior to site visit) & YES & NO & \multicolumn{2}{|c|}{ EXPLANATION (required if shaded box is checked) } \\
\hline \multicolumn{5}{|l|}{ 1. Has the Post-Closure Permit been reviewed? } \\
\hline \multicolumn{5}{|l|}{ 2. Has the Post-Closure Permit application been reviewed? } \\
\hline \multicolumn{5}{|l|}{ 3. Has the Post-Closure Plan been reviewed? } \\
\hline \multicolumn{5}{|l|}{ 4. Have the site as-built plans and site base map been reviewed? } \\
\hline \multicolumn{5}{|l|}{ 5. Have the previous inspection reports been reviewed? } \\
\hline \multirow{2}{*}{ a. Were anomalies or trends detected on previous inspections? } & & & \multirow{2}{*}{\multicolumn{2}{|c|}{$\begin{array}{l}\text { Vegetation on and around the perimeter of th } \\
\text { cover was noticed in Mar. } 2008 \text { and June } 2008 \\
\text { Vegetation removal activities were completed } \\
\text { in May } 2008 \text { and Ang. } 2008 \text {. }\end{array}$}} \\
\hline & & & & \\
\hline $\begin{array}{l}\text { If maintenance was performed, has a copy of the } \\
\text { maintenance records been obtained? }\end{array}$ & & & NA & $\begin{array}{l}\text { Maintenance records are kept in an } \\
\text { electronic database for solid waste }\end{array}$ \\
\hline \multirow{3}{*}{$\begin{array}{l}\text { 6. Have the site maintenance and repair records been reviewed? } \\
\text { a. If so, has site repair resulted in a change from as-built } \\
\text { conditions? } \\
\text { b. If yes (to } 6 \text { a), are revised as-built plans available that reflect } \\
\text { repair changes? }\end{array}$} & & & \multicolumn{2}{|r|}{ maintenance services. } \\
\hline & & & \multicolumn{2}{|l|}{ NA } \\
\hline & & & NA & \\
\hline
\end{tabular}


Inspection Requirements:

(1) Quarterly, or

(2) Rain Event of $>0.5$ inches in 24 hours

\section{POST-CLOSURE INSPECTION CHECKLIST}

\section{CAU 92: AREA 6 DECON POND FACILITY - CAS 06-05-02: Decontamination Pond (RCRA)}

\section{SITE INSPECTION PREPARATION}

Assemble the following, as needed, to conduct inspections:
a. Camera, film, and batteries
b. Keys to locks
c. Clipboard
d. Tape measure
e. Radio, pager, etc.
f. Previous Post-Closure Report, Inspection Checklists, repair records, and as-built plans
g. Other miscellaneous support equipment

\section{SITE INSPECTION}

1. Adjacent off-site features:

a. Are there any new activities or features on Yucca Lake that could potentially affect the site (e.g., activities that change the flow of surface water or are encroaching the unit)?

2. Fencing, gates, and signs:

a. Is there damage to or a break in the fence?

b. Have any fenceposts been damaged or their anchoring weakened?

c. Are any of the use restriction signs damaged or missing?

d. Are all use restriction signs legible?

e. How many use restriction signs need to be replaced?

f. Are any of the URMA signs damaged or missing?

g. Are all URMA signs legible?

h. How many URMA signs need to be replaced?

i. Is the gate intact and functional?

j. Does the gate show evidence of tampering or damage?

k. Was the gate locked?

I. Does the wave barrier require repair?

$\mathrm{m}$. Is there standing water within or at the fenceline?

If yes, what is the playa water elevation, as measured on the depth gauge attached to the fence perimeter?

n. Other?

3. Waste unit cover:

a. Is there evidence of settling?

b. Is there evidence of cracking?

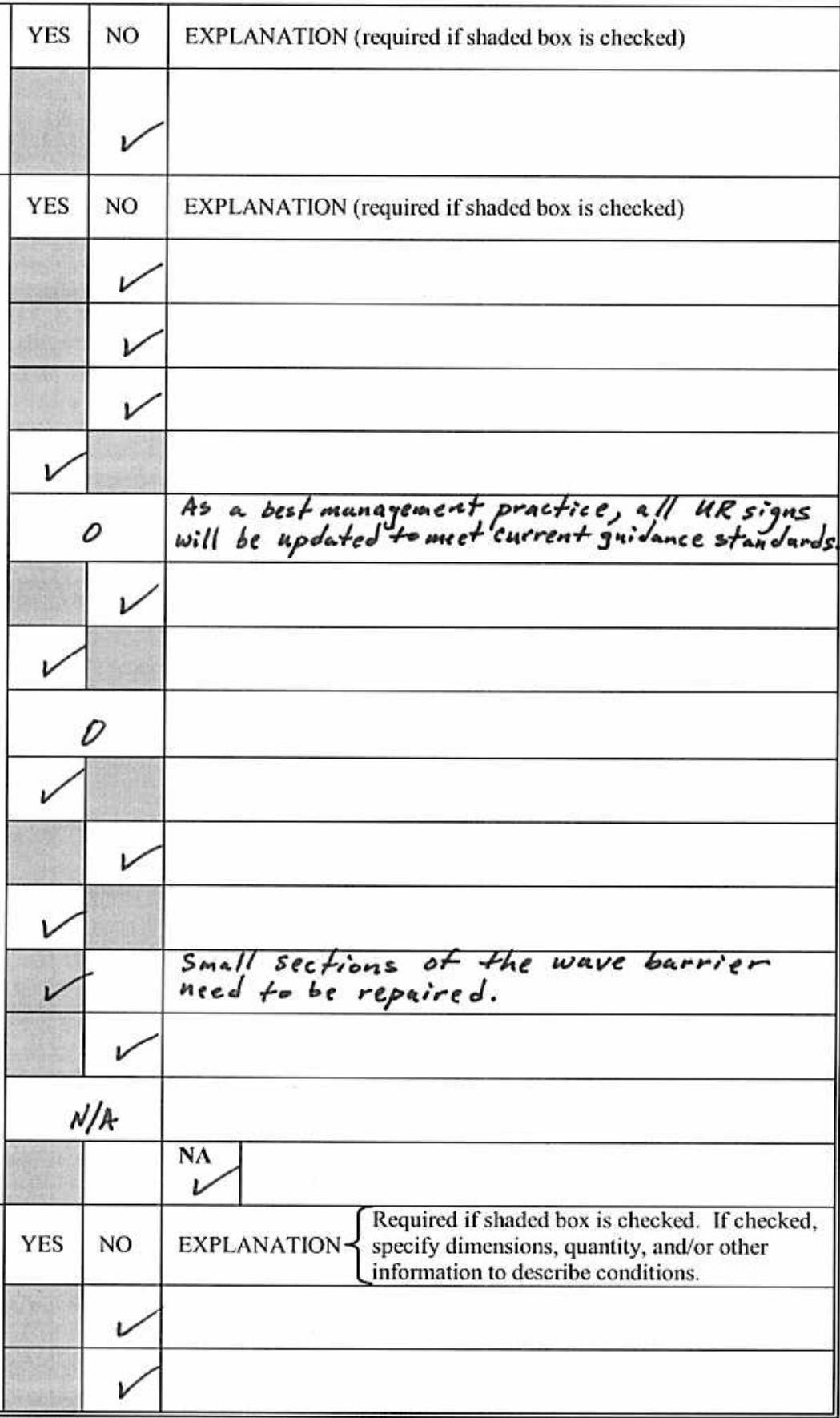


Inspection Requirements:

(1) Quarterly, or

(2) Rain Event of $>0.5$ inches in 24 hours

\section{POST-CLOSURE INSPECTION CHECKLIST}

\section{CAU 92: AREA 6 DECON POND FACILITY - CAS 06-05-02: Decontamination Pond (RCRA)}

3. Waste unit cover (continued):

c. Is there evidence of erosion (wind or water)?

d. Is there evidence of human intrusion onto the cover?

e. Is there evidence of large animal intrusion onto the cover?

f. Is there evidence of animal burrowing?

g. Is vegetation growing on the cover?

h. Other (including trash, debris, etc within fenced area)?

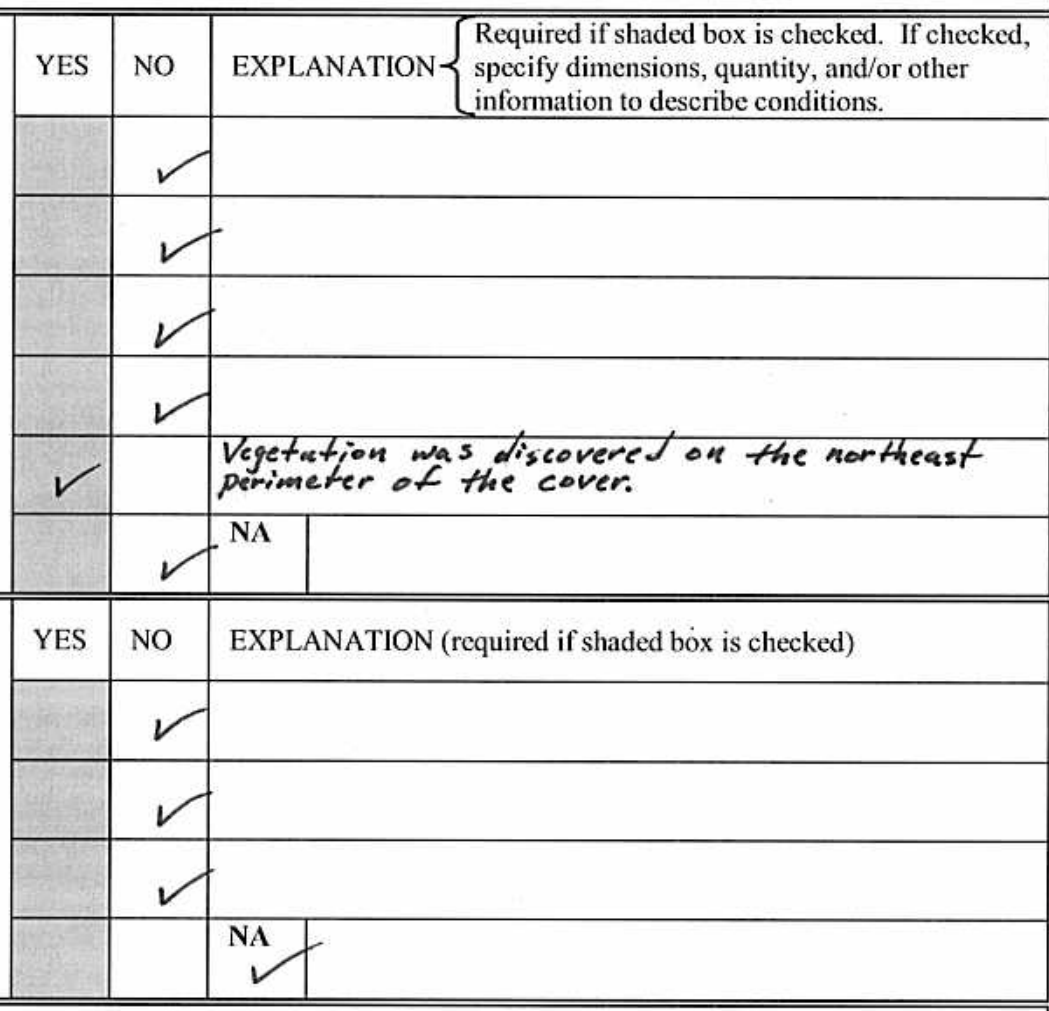

5. Photograph Instructions:

A total of 8 photographs must be taken during each inspection of CAU 92. Additional photographs may also be taken. The required photographs shall be taken as follows:

- Four (4) from the center of the unit, one in each compass direction (i.e., N, S, E, W) and

- Four (4) of the unit from outside the fence, one in each compass direction.

6. Photograph Documentation:

a. Have all photographs been taken as required by the photograph instructions?

b. Has a photograph log been prepared?

c. How many photographs were taken?

d. Other?

\section{E. FIELD CONCLUSIONS}

1. Are more frequent inspections required?

2. Are existing maintenance/repair actions satisfactory?

3. Is other maintenance/repair necessary?

4. Is there an imminent hazard to the integrity of the site? (Immediate report required)

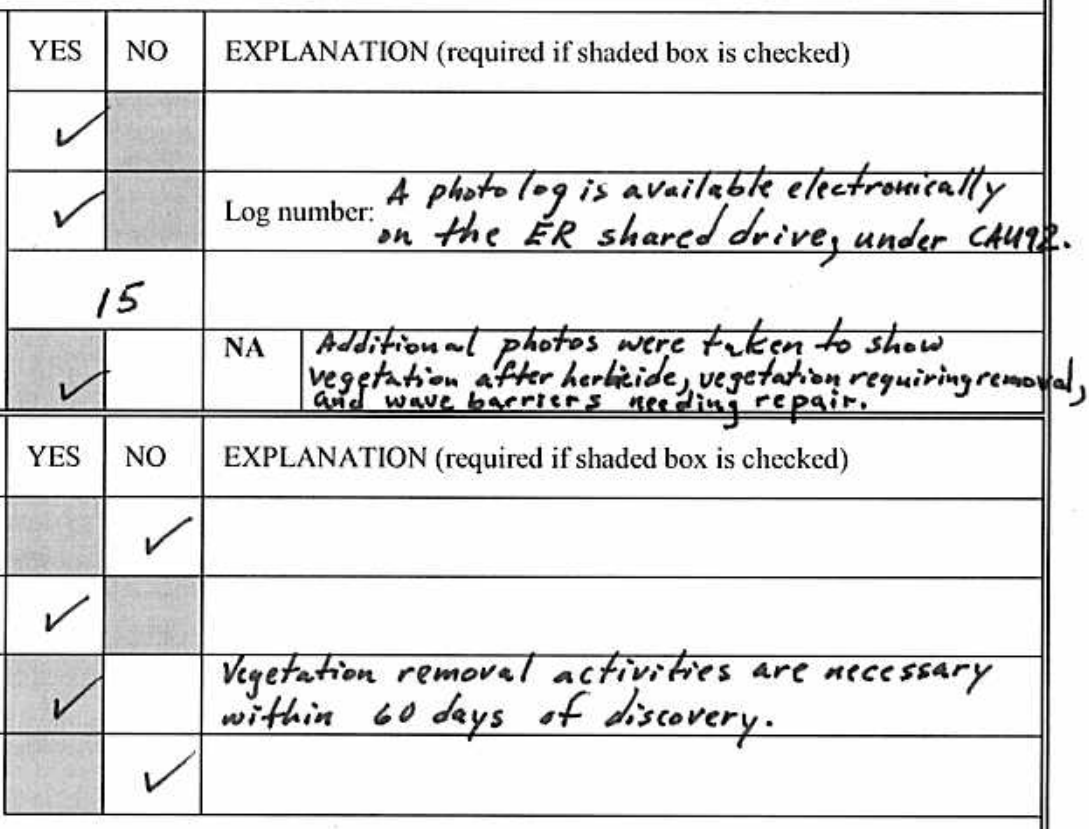

Date reported:

Person/Agency to whom report was made: 
Inspection Requirements:

(1) Quarterly, or

(2) Rain Event of $>0.5$ inches in 24 hours

POST-CLOSURE INSPECTION CHECKLIST

CAU 92: AREA 6 DECON POND FACILITY - CAS 06-05-02: Decontamination Pond (RCRA)

5. Field conclusionsirecommendations: The site is secured. The uR signage and chain link fencing are in great condition. There were some open gaps noticed in the wave barriers on the east side of the fence. Repairs will be made to those wave barrier sections. In addition, vegetation was noticed on the northeast corner of the cover that will have to be removed. Maintenance/repair activities will be completed within 60 days.

\section{F. CERTIFICATION}

I have conducted an inspection of CAU 92, Area 6 Decon Pond Facility, in accordance with the procedures of the Post-Closure Permit (including the Post-Closure Plan) as recorded on this checklist, attached sheets, field notes, photographs, and photograph logs.

\begin{tabular}{l|l}
\hline Chief Inspector's Signature: & Date: $9 / 23 / 08$ \\
\hline Printed Name: Glenn Richardson & Title: Task Manager
\end{tabular}

Attachments (check if attached):

घ Field Notes

$\square$ Photos

$\square$ Maintenance records 
RCRA Post-Closure Report

Revision: 0

Date: December 2008

\section{CoRRECTIVE ACTION UNIT 110 InSPECTION CHECKLISTS}


RCRA Post-Closure Report

Revision: 0

Date: December 2008

THIS PAGE INTENTIONALLY LEFT BLANK 


\begin{tabular}{|c|c|c|c|c|}
\hline \multicolumn{5}{|c|}{ POST-CLOSURE INSPECTION CHECKLIST } \\
\hline \multicolumn{3}{|c|}{ CAU 110: AREA 3 WMD U-3ax/bl CRATER - } & \multicolumn{2}{|c|}{ CAS 03-23-04: U-3axbl Subsidence Crater } \\
\hline \multicolumn{2}{|l|}{ Inspection Date and Time: $\quad 9 / 23 / 08 \quad 10: 32 \mathrm{AM}$} & \multicolumn{3}{|c|}{ Reason for Inspection: Quarterly } \\
\hline \multicolumn{2}{|l|}{ Date of Last Post-Closure Inspection: } & \multicolumn{3}{|c|}{ Reason for Last Post-Closure Inspection: Quarter/y } \\
\hline \multicolumn{5}{|c|}{ Responsible Entity: NSTec Environmental Restoration, Nevada Test Site, Mercury, Nevada } \\
\hline \multicolumn{5}{|c|}{ Responsible Facility Owner: Thomas A. Thiele, Project Manager, Industrial Sites, Environmental Restoration Project } \\
\hline Chief Inspector: Glenn Richardson Title: Ta & \multicolumn{3}{|c|}{ Title: Task Manager } & Organization: Environmental Restoration \\
\hline 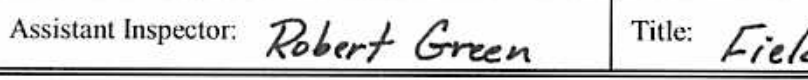 & \multicolumn{3}{|c|}{ Title: Field Technica/ Lead } & Organization: Environmental Restoration \\
\hline \multicolumn{5}{|c|}{$\begin{array}{l}\text { A. GENERAL INSTRUCTIONS } \\
\text { 1. All checklist items must be completed and detailed comments made to document the results of the site inspection. The completed checklist is part } \\
\text { of the field record of the inspection. Additional pages should be used as necessary to ensure that a complete record is made. Attach the } \\
\text { additional pages and number all pages upon completion of the inspection. } \\
\text { 2. Any checklist line item marked by an inspector in a SHADED BOX must be fully explained or an appropriate reference to previous reports } \\
\text { provided. The purpose of this requirement is to provide a written explanation of inspector observations and the inspector's rationale for } \\
\text { conclusions and recommendations. Explanations are to be placed on additional attachments and cross-referenced appropriately. Explanations, in } \\
\text { addition to narrative, will take the form of sketches, measurements, and annotated site maps. } \\
\text { 3. The site inspection is a walking inspection of the entire site including the perimeter and sufficient transects to be able to inspect the entire surface } \\
\text { and all features specifically described in this checklist. } \\
\text { 4. A standard set of color photographs is required. In addition, all anomalous features or new features (such as changes in adjacent area land use) are } \\
\text { to be photographed. A photograph log entry will be made for each photograph taken. } \\
\text { 5. Field notes taken to assist in completion of this checklist will become part of the inspection record. No form is specified for field notes; however, } \\
\text { they must be legible and in sufficient detail to enable review by succeeding inspectors and the responsible agency. } \\
\text { 6. This unit will be inspected quarterly with formal reporting to the Nevada Division of Environmental Protection to be done annually. The annual } \\
\text { report will include an executive summary, this inspection checklist with field notes and photograph log attached, and recommendations and } \\
\text { conclusions. }\end{array}$} \\
\hline B. PREPARATION (To be competed prior to site visit) & YES & NO & EXPL & (required if shaded box is checked) \\
\hline \multicolumn{5}{|l|}{ 1. Has the Post-Closure Permit been reviewed? } \\
\hline 2. Has the Post-Closure Permit application been reviewed? & & & & \\
\hline 3. Has the Post-Closure Plan been reviewed? & & & & \\
\hline 4. Have the site as-built plans and site base map been reviewed? & & & & \\
\hline 5. Have the previous inspection reports been reviewed? & & & & \\
\hline a. Were anomalies or trends detected on previous inspections? & & & & \\
\hline b. Was maintenance performed? & & & & \\
\hline $\begin{array}{l}\text { If maintenance was performed, has a copy of the } \\
\text { maintenance records been obtained? }\end{array}$ & & & NA & \\
\hline \multicolumn{5}{|l|}{ 6. Have the site maintenance and repair records been reviewed? } \\
\hline $\begin{array}{l}\text { a. If so, has site repair resulted in a change from as-built } \\
\text { conditions? }\end{array}$ & & & NA & \\
\hline $\begin{array}{l}\text { b. If yes (to } 6 \mathrm{a} \text { ), are revised as-built plans available that reflect } \\
\text { repair changes? }\end{array}$ & & & NA & \\
\hline
\end{tabular}




\section{POST-CLOSURE INSPECTION CHECKLIST}

\section{CAU 110: AREA 3 WMD U-3ax/bl CRATER - CAS 03-23-04: U-3axbl Subsidence Crater}

\section{SITE INSPECTION PREPARATION}

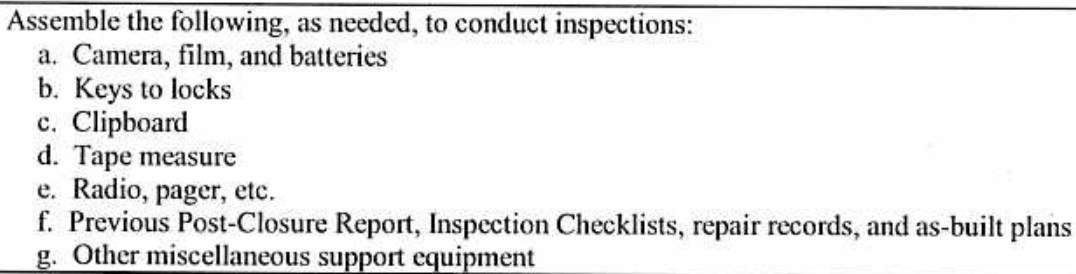

\section{SITE INSPECTION}

1. Adjacent off-site features:

a. Are there any new activities or features in the vicinity that could potentially affect the site (e.g., activities that change the flow of surface water or are encroaching the unit)?

2. Fences, gates, and signs:

a. Is there damage to or a break in the fence?

b. Is there damage to or a break in the chicken wire fence?

c. Have any fenceposts been damaged or their anchoring weakened?

d. Is the gate intact and functional?

e. Does the gate show evidence of tampering or damage?

f. Was the gate locked?

g. Are any of the use restriction signs damaged or missing?

h. Are all use restriction signs legible?

i. How many use restriction signs need to be replaced?

j. Other?

3. Waste unit cover (Western portion, "ax"):

a. Is there evidence of settling?

b. Is there evidence of cracking?

c. Is there evidence of erosion (wind or water)?

d. Is there evidence of human intrusion onto the cover?

e. Is there evidence of large animal intrusion onto the cover?

f. Is there evidence of animal burrowing?

g. Is there a change or difference in vegetation (i.e., is the vegetation growing on the cover inconsistent with the naturally-occurring vegetation growing outside of the unit)?

h. Other (including trash, debris, etc within fenced area)?

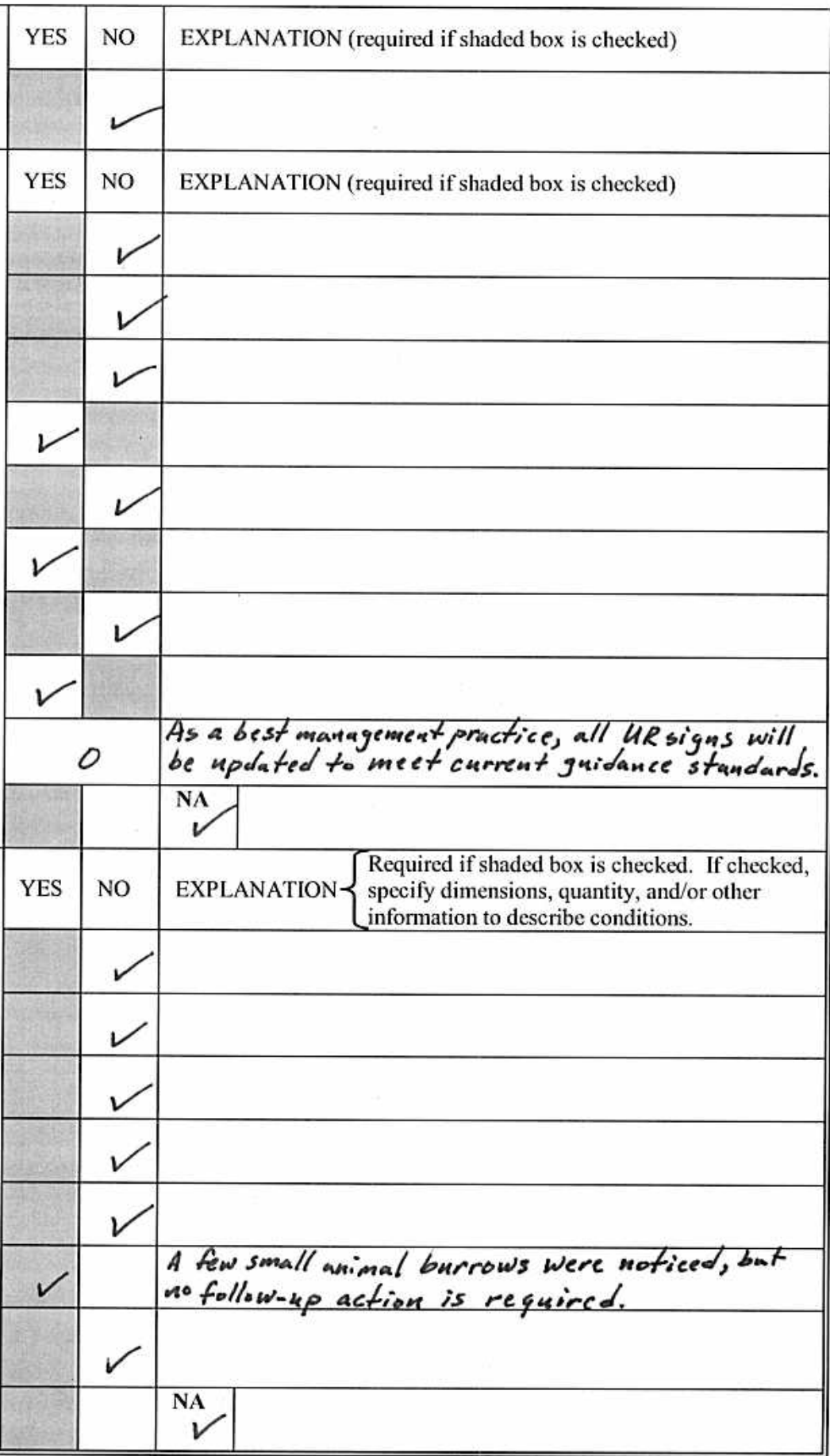




\section{POST-CLOSURE INSPECTION CHECKLIST}

\section{CAU 110: AREA 3 WMD U-3ax/bl CRATER - CAS 03-23-04: U-3axbl Subsidence Crater}

4. Waste unit cover (Eastern portion, "bx"):

a. Is there evidence of settling?

b. Is there evidence of cracking?

c. Is there evidence of erosion (wind or water)?

d. Is there evidence of human intrusion onto the cover?

e. Is there evidence of large animal intrusion onto the cover?

f. Is there evidence of animal burrowing?

g. Is there a change or difference in vegetation (i.e., is the vegetation growing on the cover inconsistent with the naturally-occurring vegetation growing outside of the unit)?

h. Other (including trash, debris, etc within fenced area)?

5. Subsidence survey markers and TDR Probes:

a. Have any of the 7 subsidence survey markers been disturbed?

b. Do natural processes threaten the integrity of any subsidence survey marker?

c. Is there excessive vegetation around the subsidence survey markers?

d. Is there any evidence that TDR probes have been disturbed or the wires damaged?

e. Other?

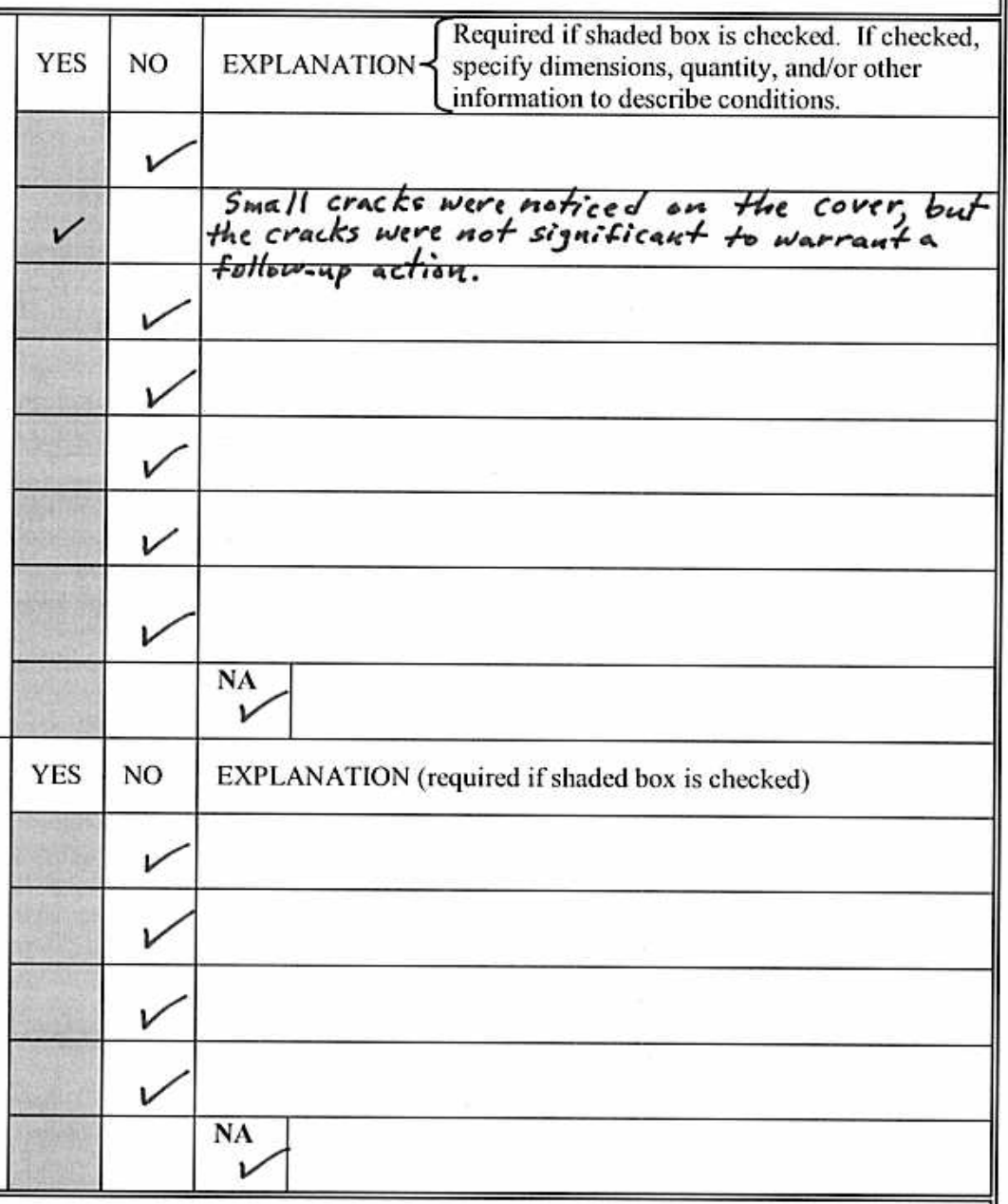

6. Photograph Instructions:

A total of 8 photographs are required to be taken during each inspection of CAU 110. Additional photographs may also be taken. The required photographs shall be taken as follows:

- Four (4) from the center of the unit, one in each compass direction (i.e., N, S, E, W) and

- Four (4) of the unit from outside the fence, one in each compass direction.

7. Photograph Documentation:

a. Have all photographs been taken as required by the photograph instructions?

b. Has a photograph $\log$ been prepared?

c. How many photographs were taken?

d. Other?

\section{E. FIELD CONCLUSIONS}

1. Are more frequent inspections required?

2. Are existing maintenance/repair actions satisfactory?

3. Is other maintenance/repair necessary?

\begin{tabular}{|c|c|c|}
\hline YES & NO & EXPLANATION (required if shaded box is checked) \\
\hline$\checkmark$ & & $\begin{array}{l}\text { Log number: An electronic log is available on the } \\
E R \text { Shared Drive, under CAn } 110 \text {. }\end{array}$ \\
\hline \multicolumn{3}{|c|}{8} \\
\hline & & $\begin{array}{c}\text { NA } \\
V \\
\end{array}$ \\
\hline YES & NO & EXPLANATION (required if shaded box is checked) \\
\hline & $\checkmark$ & \\
\hline$\checkmark$ & & \\
\hline & $v$ & \\
\hline
\end{tabular}




\section{POST-CLOSURE INSPECTION CHECKLIST}

\section{CAU 110: AREA 3 WMD U-3ax/bl CRATER - CAS 03-23-04: U-3axbl Subsidence Crater}

\begin{tabular}{||l|l|l|l|}
\hline \hline E. FIELD CONCLUSIONS (continued) & YES & NO & EXPLANATION (required if shaded box is checked) \\
\hline $\begin{array}{c}\text { 4. Is there an imminent hazard to the integrity of the unit? } \\
\text { (Immediate report required) }\end{array}$ & & &
\end{tabular}

Person/Agency to whom report was made:

5. Field conclusions/recommendations: The fencing and $U R$ sigus are in good condition. Subsidence repair areas appear to be intact and well-maintained. Miner evidence of animal burrows. Noticed some small cracts, but nothing was determined signiticant warranting followiup action. Overall sife conditions are good aud there ure no issues.

\section{F. CERTIFICATION}

I have conducted an inspection of CAU 110, Area 3 WMD U-3ax/bl Crater, in accordance with the procedures of the Post-Closure Permit (including the Post-Closure Plan) as recorded on this checklist, attached sheets, field notes, photographs, and photograph logs.

Chief Inspector's Signature:

Printed Name: Glenn Richardson

$9 / 23 / 08$

Title: Task Manager

Attachments (check if attached):

$\square$ Field Notes

$\square$ Photos

$\square$ Maintenance records 
RCRA Post-Closure Report

Revision: 0

Date: December 2008

\section{CORRECTIVE ACTION UNIT 112 INSPECTION CHECKLISTS}


RCRA Post-Closure Report

Revision: 0

Date: December 2008

THIS PAGE INTENTIONALLY LEFT BLANK 


\section{POST-CLOSURE INSPECTION CHECKLIST}

\section{CAU 112: AREA 23 HAZARDOUS WASTE TRENCHES - CAS 23-21-02: Area 23 Haz. Waste Trenches (RCRA)}

\begin{tabular}{|c|c|c|}
\hline Inspection Date and Time: $12 / 18107$ & $12: 02 \mathrm{PM}$ & Reason for Inspection: \\
\hline Date of Last Post-Closure Inspection: $\quad 9,27$ & 07 & Reason for Last Post-Closure Inspection: \\
\hline
\end{tabular}

Responsible Entity: NSTec Environmental Restoration, Nevada Test Site, Mercury, Nevada

Responsible Facility Owner: Jeffrey L. Smith, Deputy Manager, Environmental Restoration

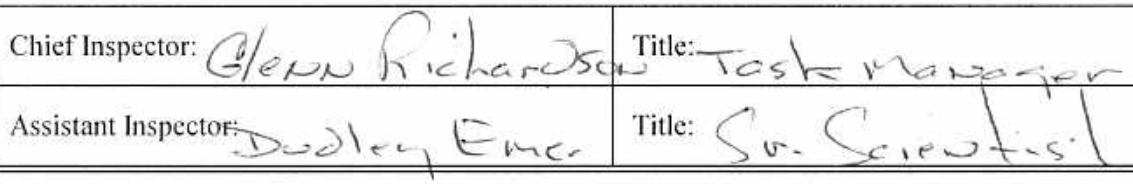

Organization: Environmental Restoration

Organization: Environmental Restoration

\section{A. GENERAL INSTRUCTIONS}

1. All checklist items must be completed and detailed comments made to document the results of the site inspection. The completed checklist is part of the field record of the inspection. Additional pages should be used as necessary to ensure that a complete record is made. Attach the additional pages and number all pages upon completion of the inspection.

2. Any checklist line item marked by an inspector in a SHADED BOX must be fully explained or an appropriate reference to previous reports provided. The purpose of this requirement is to provide a written explanation of inspector observations and the inspector's rationale for conclusions and recommendations. Explanations are to be placed on additional attachments and cross-referenced appropriately. Explanations, in addition to narrative, will take the form of sketches, measurements, and annotated site maps.

3. The site inspection is a walking inspection of the entire site including the perimeter and sufficient transects to be able to inspect the entire surface and all features specifically described in this checklist.

4. Field notes taken to assist in completion of this checklist will become part of the inspection record. No form is specified for field notes; however, they must be legible and in sufficient detail to enable review by succeeding inspectors and the responsible agency.

5. This unit will be inspected quarterly with formal reporting to the Nevada Division of Environmental Protection to be done annually. The annual report will include an executive summary, this inspection checklist with field notes attached, and recommendations and conclusions.

\section{B. PREPARATION (To be competed prior to site visit)}

1. Has the Post-Closure Permit been reviewed?

2. Has the Post-Closure Permit application been reviewed?

3. Has the Post-Closure Plan been reviewed?

4. Have the site as-built plans and site base map been reviewed?

5. Have the previous inspection reports been reviewed?

a. Were anomalies or trends detected on previous inspections?

b. Was maintenance performed?

If maintenance was performed, has a copy of the maintenance records been obtained?

6. Have the site maintenance and repair records been reviewed?

a. If so, has site repair resulted in a change from as-built conditions?

b. If yes (to 6a), are revised as-built plans available that reflect repair changes?

\begin{tabular}{|l|l|l|l|}
\hline YES & NO & \multicolumn{2}{|l|}{ EXPLANATION (required if shaded box is checked) } \\
\hline & & \multicolumn{2}{|l|}{} \\
\hline & & & \\
\hline & & & \\
\hline & & & \\
\hline & & NA & \\
\hline & & \multicolumn{2}{|l|}{} \\
\hline & & NA & \\
\hline & & & \\
\hline
\end{tabular}

\section{SITE INSPECTION PREPARATION}

Assemble the following, as needed, to conduct inspections:
a. Camera, film, and batteries
e. Radio, pager, etc.
b. Keys to locks
f. Previous Post-Closure Report, Inspection Checklists, repair records, and as-built plans
c. Clipboard
g. Other miscellaneous support equipment

d. Tape measure 


\section{POST-CLOSURE INSPECTION CHECKLIST}

\section{CAU 112: AREA 23 HAZARDOUS WASTE TRENCHES - CAS 23-21-02: Area 23 Haz. Waste Trenches (RCRA)}

\section{SITE INSPECTION}

1. Adjacent off-site features:

a. Are there any new activities or features in the vicinity that could potentially affect the site (e.g., activities that change the flow of surface water or are encroaching the unit)?

2. Fences, gates, and signs (East Fenced Enclosure):

a. Is there damage to or a break in the fence?

b. Have any fenceposts been damaged or their anchoring weakened?

c. Is the gate intact and functional?

d. Does the gate show evidence of tampering or damage?

e. Was the gate locked?

f. Are any of the use restriction signs damaged or missing?

g. Are all use restriction signs legible?

h. How many use restriction signs need to be replaced?

i. Other?

3. Monuments:

a. Have landfill monuments been disturbed?

b. Do natural processes threaten the integrity of any landfill monuments?

c. Is there excessive vegetation around the landfill monuments?

d. Other?

4. Waste unit cover:

a. Is there evidence of settling?

b. Is there evidence of cracking?

c. Is there evidence of erosion (wind or water)?

d. Is there evidence of human intrusion onto the cover?

e. Is there evidence of large animal intrusion onto the cover?

f. Is there evidence of animal burrowing?

$\mathrm{g}$. Is vegetation growing on the cover?

h. Other (including trash, debris, etc within fenced area)?

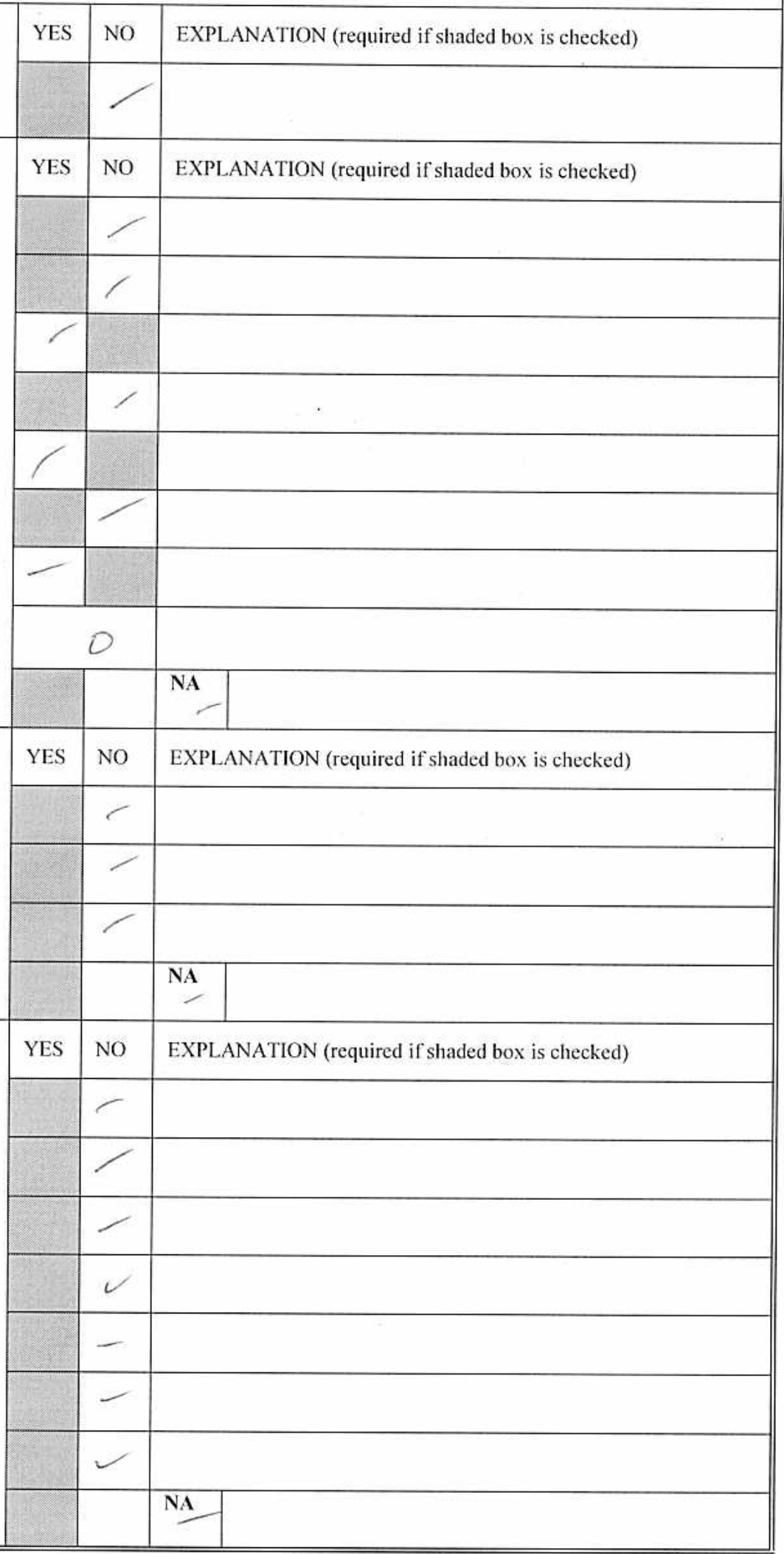




\section{POST-CLOSURE INSPECTION CHECKLIST}

\section{CAU 112: AREA 23 HAZARDOUS WASTE TRENCHES - CAS 23-21-02: Area 23 Haz. Waste Trenches (RCRA)}

\begin{tabular}{|c|c|c|c|}
\hline 5. Photograph Documentation (optional): & YES & NO & EXPLANATION \\
\hline \multicolumn{4}{|l|}{ a. Have photographs been taken of the site? } \\
\hline \multicolumn{4}{|l|}{ If yes, how many photos were taken? } \\
\hline If yes, has a photographic log been prepared? & & & Log number: \\
\hline E. FIELD CONCLUSIONS & YES & NO & EXPLANATION (required if shaded box is checked) \\
\hline \multicolumn{4}{|l|}{ 1. Are more frequent inspections required? } \\
\hline \multicolumn{4}{|l|}{ 2. Are existing maintenance/repair actions satisfactory? } \\
\hline \multicolumn{4}{|l|}{ 3. Is other maintenance/repair necessary? } \\
\hline $\begin{array}{l}\text { 4. Is there an imminent hazard to the integrity of the site? } \\
\text { (Immediate report required) }\end{array}$ & & & \\
\hline
\end{tabular}

Date reported:

Person/Agency to whom report was made:

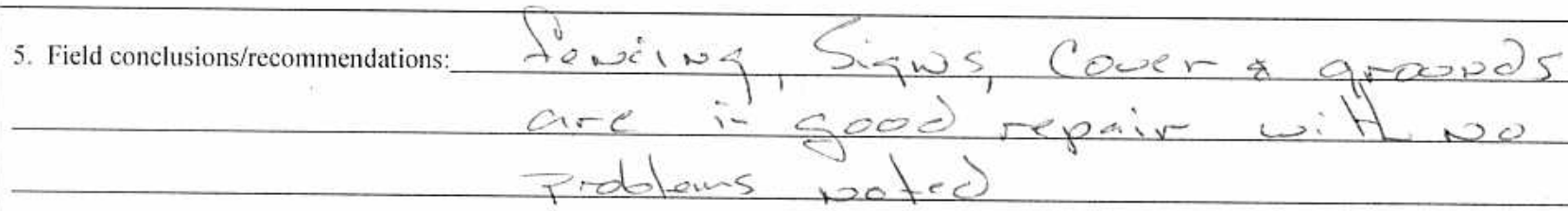

\section{F. CERTIFICATION}

I have conducted an inspection of CAU 112, Area 23 Hazardous Waste Trenches, in accordance with the procedures of the Post-Closure Permit (including the Post-Closure Plan) as recorded on this checklist, attached sheets, and field notes.

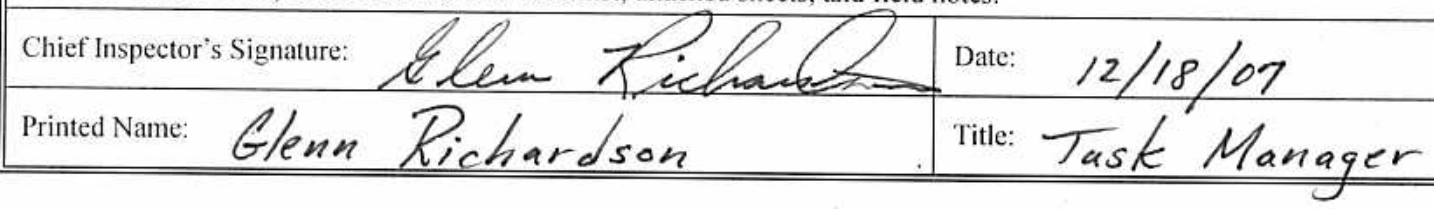

Attachments (check if attached):
[1 Field Notes
$\square$ Maintenance records 


\section{POST-CLOSURE INSPECTION CHECKLIST}

\section{CAU 112: AREA 23 HAZARDOUS WASTE TRENCHES - CAS 23-21-02: Area 23 Haz. Waste Trenches (RCRA)}

\begin{tabular}{|l|l|}
\hline \hline Inspection Date and Time: $3 / 26 / 08 \quad 12: 28 \mathrm{PM}$ & Reason for Inspection: Quarfer/y \\
\hline Date of Last Post-Closure Inspection: $12 / 18 / 07$ & Reason for Last Post-Closure Inspection: Quarter/y \\
\hline Responsible Entity: NSTec Environmental Restoration, Nevada Test Site, Mercury, Nevada
\end{tabular}

Responsible Facility Owner: Thomas A. Thiele, Project Manager, Industrial Sites, Environmental Restoration Project

\begin{tabular}{|l|l|l||}
\hline Chief Inspector: Glenn Kichardson & Title: Task Manager & Organization: Environmental Restoration \\
\hline Assistant Inspector: Mike Floyd & Title: Field Technica/ Lead & Organization: Environmental Restoration \\
\hline \hline
\end{tabular}

A. GENERAL INSTRUCTIONS

1. All checklist items must be completed and detailed comments made to document the results of the site inspection. The completed checklist is part of the field record of the inspection. Additional pages should be used as necessary to ensure that a complete record is made. Attach the additional pages and number all pages upon completion of the inspection.

2. Any checklist line item marked by an inspector in a SHADED BOX must be fully explained or an appropriate reference to previous reports provided. The purpose of this requirement is to provide a written explanation of inspector observations and the inspector's rationale for conclusions and recommendations. Explanations are to be placed on additional attachments and cross-referenced appropriately. Explanations, in addition to narrative, will take the form of sketches, measurements, and annotated site maps.

3. The site inspection is a walking inspection of the entire site including the perimeter and sufficient transects to be able to inspect the entire surface and all features specifically described in this checklist.

4. Field notes taken to assist in completion of this checklist will become part of the inspection record. No form is specified for field notes; however, they must be legible and in sufficient detail to enable review by succeeding inspectors and the responsible agency.

5. This unit will be inspected quarterly with formal reporting to the Nevada Division of Environmental Protection to be done annually. The annual report will include an executive summary, this inspection checklist with field notes attached, and recommendations and conclusions.

\begin{tabular}{|c|c|c|c|}
\hline B. PREPARATION (To be competed prior to site visit) & YES & NO & EXPLANATION (required if shaded box is checked) \\
\hline \multicolumn{4}{|l|}{ 1. Has the Post-Closure Permit been reviewed? } \\
\hline \multicolumn{4}{|l|}{ 2. Has the Post-Closure Permit application been reviewed? } \\
\hline \multicolumn{4}{|l|}{ 3. Has the Post-Closure Plan been reviewed? } \\
\hline \multicolumn{4}{|l|}{ 4. Have the site as-built plans and site base map been reviewed? } \\
\hline \multicolumn{4}{|l|}{ 5. Have the previous inspection reports been reviewed? } \\
\hline \multicolumn{4}{|l|}{ a. Were anomalies or trends detected on previous inspections? } \\
\hline \multicolumn{4}{|l|}{ b. Was maintenance performed? } \\
\hline $\begin{array}{l}\text { If maintenance was performed, has a copy of the } \\
\text { maintenance records been obtained? }\end{array}$ & & & NA \\
\hline \multicolumn{4}{|l|}{ 6. Have the site maintenance and repair records been reviewed? } \\
\hline $\begin{array}{l}\text { a. If so, has site repair resulted in a change from as-built } \\
\text { conditions? }\end{array}$ & & & NA \\
\hline $\begin{array}{l}\text { b. If yes (to } 6 \mathrm{a} \text { ), are revised as-built plans available that reflect } \\
\text { repair changes? }\end{array}$ & & & NA \\
\hline
\end{tabular}

\section{SITE INSPECTION PREPARATION}

Assemble the following, as needed, to conduct inspections:
a. Camera, film, and batteries
e. Radio, pager, etc.
b. Keys to locks
f. Previous Post-Closure Report, Inspection Checklists, repair records, and as-built plans
c. Clipboard

d. Tape measure 


\section{POST-CLOSURE INSPECTION CHECKLIST}

\section{CAU 112: AREA 23 HAZARDOUS WASTE TRENCHES - CAS 23-21-02: Area 23 Haz. Waste Trenches (RCRA)}

\section{SITE INSPECTION}

1. Adjacent off-site features:

a. Are there any new activities or features in the vicinity that could potentially affect the site (e.g., activities that change the flow of surface water or are encroaching the unit)?

2. Fences, gates, and signs (East Fenced Enclosure):

a. Is there damage to or a break in the fence?

b. Have any fenceposts been damaged or their anchoring weakened?

c. Is the gate intact and functional?

d. Does the gate show evidence of tampering or damage?

e. Was the gate locked?

f. Are any of the use restriction signs damaged or missing?

g. Are all use restriction signs legible?

h. How many use restriction signs need to be replaced?

i. Other?

3. Monuments:

a. Have landfill monuments been disturbed?

b. Do natural processes threaten the integrity of any landfill monuments?

c. Is there excessive vegetation around the landfill monuments?

d. Other?

4. Waste unit cover:

a. Is there evidence of settling?

b. Is there evidence of cracking?

c. Is there evidence of erosion (wind or water)?

d. Is there evidence of human intrusion onto the cover?

e. Is there evidence of large animal intrusion onto the cover?

f. Is there evidence of animal burrowing?

g. Is vegetation growing on the cover?

h. Other (including trash, debris, etc within fenced area)?

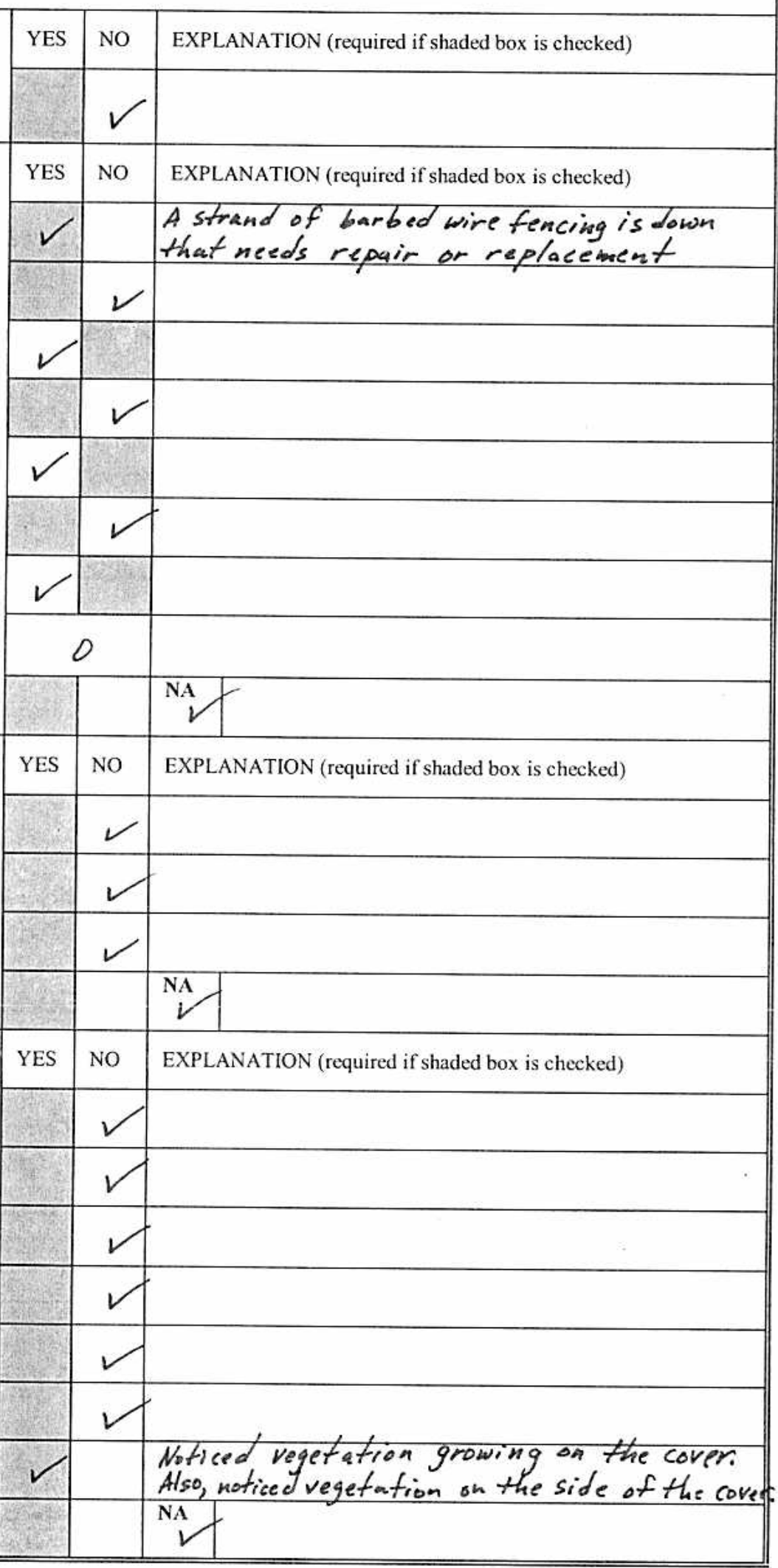




\section{POST-CLOSURE INSPECTION CHECKLIST}

\section{CAU 112: AREA 23 HAZARDOUS WASTE TRENCHES - CAS 23-21-02: Area 23 Haz. Waste Trenches (RCRA)}

5. Photograph Documentation (optional):

a. Have photographs been taken of the site?

If yes, how many photos were taken?

If yes, has a photographic log been prepared?

\begin{tabular}{||l}
\hline E. FIELD CONCLUSIONS \\
\hline 1. Are more frequent inspections required? \\
\hline 2. Are existing maintenance/repair actions satisfactory? \\
\hline 3. Is other maintenance/repair necessary? \\
\hline $\begin{array}{c}\text { 4. Is there an imminent hazard to the integrity of the site? } \\
\text { (Immediate report required) }\end{array}$
\end{tabular}

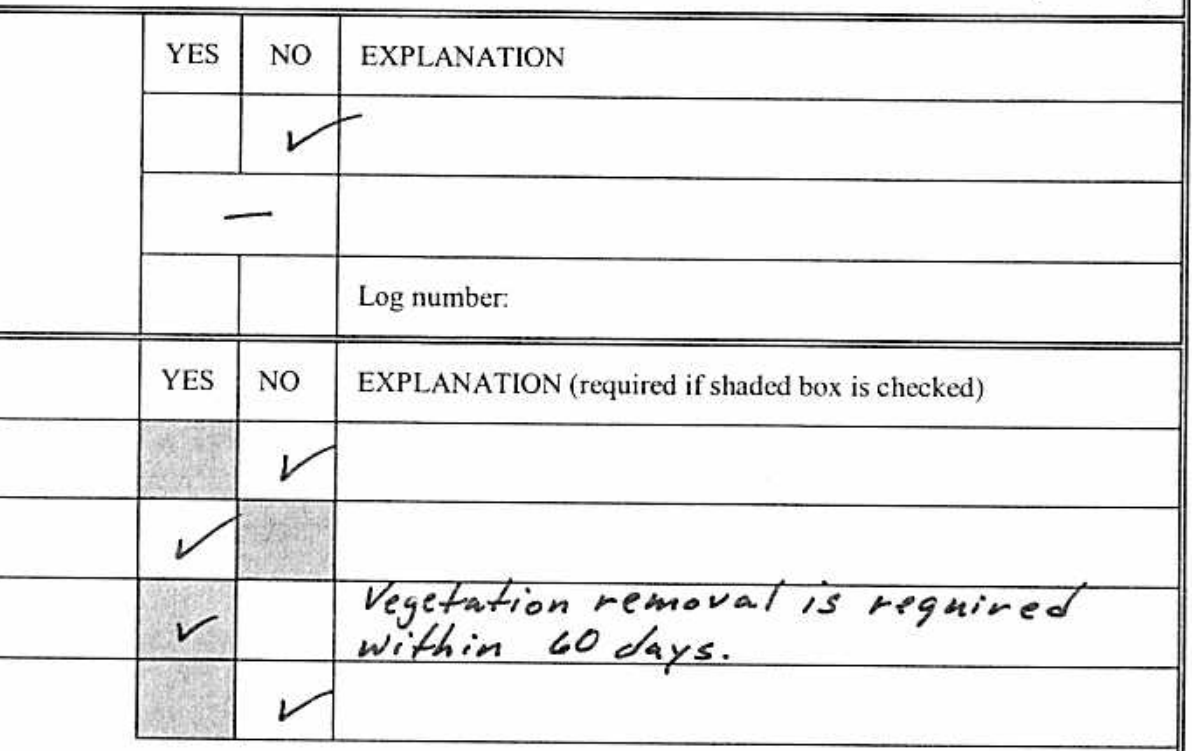

Date reported:

Person/Agency to whom report was made:

5. Field conclusions/recommendations: The signage and aboveground monuments are in excellent condition. Also, the rip rap is maintained very well. There are no erosion problems or snbsidence on the cover. However, vegetation growth was noticed on top and along the side slope of the cover. Vegetation will be removed and an herbicide will applied to prevent vegetation growth in the near future.

\section{F. CERTIFICATION}

I have conducted an inspection of CAU 112, Area 23 Hazardous Waste Trenches, in accordance with the procedures of the Post-Closure Permit (including the Post-Closure Plan) as recorded on this checklist, attached sheets, and field notes.

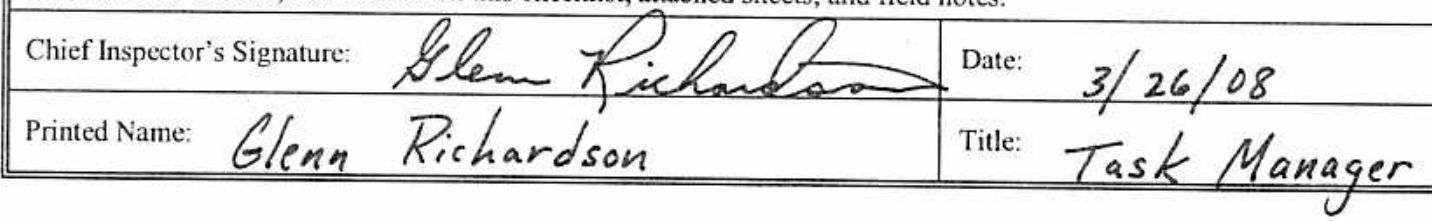

Attachments (check if attached):

$\square$ Field Notes

Maintenance records 


\section{POST-CLOSURE INSPECTION CHECKLIST}

\section{CAU 112: AREA 23 HAZARDOUS WASTE TRENCHES - CAS 23-21-02: Area 23 Haz. Waste Trenches (RCRA)}

\begin{tabular}{|l|l}
\hline Inspection Date and Time: $6 / 17 / 08 / 220$ & Reason for Inspection: QUARtERLG \\
\hline Date of Last Post-Closure Inspection: $3 / 26 / 08$ & Reason for Last Post-Closure Inspection: QuARtenLy
\end{tabular}

Responsible Entity: NSTec Environmental Restoration, Nevada Test Site, Mercury, Nevada

Responsible Facility Owner: Thomas A. Thiele, Project Manager, Industrial Sites, Environmental Restoration Project

\begin{tabular}{||l|l|l||}
\hline Chief Inspector: M, Ke F/OMD & Title: FTC & Organization: Environmental Restoration \\
\hline Assistant Inspector: Pay & Title: Fom & Organization: Environmental Restoration \\
\hline
\end{tabular}

\section{A. GENERAL INSTRUCTIONS}

1. All checklist items must be completed and detailed comments made to document the results of the site inspection. The completed checklist is part of the field record of the inspection. Additional pages should be used as necessary to ensure that a complete record is made. Attach the additional pages and number all pages upon completion of the inspection.

2. Any checklist line item marked by an inspector in a SHADED BOX must be fully explained or an appropriate reference to previous reports provided. The purpose of this requirement is to provide a written explanation of inspector observations and the inspector's rationale for conclusions and recommendations. Explanations are to be placed on additional attachments and cross-referenced appropriately. Explanations, in addition to narrative, will take the form of sketches, measurements, and annotated site maps.

3. The site inspection is a walking inspection of the entire site including the perimeter and sufficient transects to be able to inspect the entire surface and all features specifically described in this checklist.

4. Field notes taken to assist in completion of this checklist will become part of the inspection record. No form is specified for field notes; however, they must be legible and in sufficient detail to enable review by succeeding inspectors and the responsible agency.

5. This unit will be inspected quarterly with formal reporting to the Nevada Division of Environmental Protection to be done annually. The annual report will include an executive summary, this inspection checklist with field notes attached, and recommendations and conclusions.

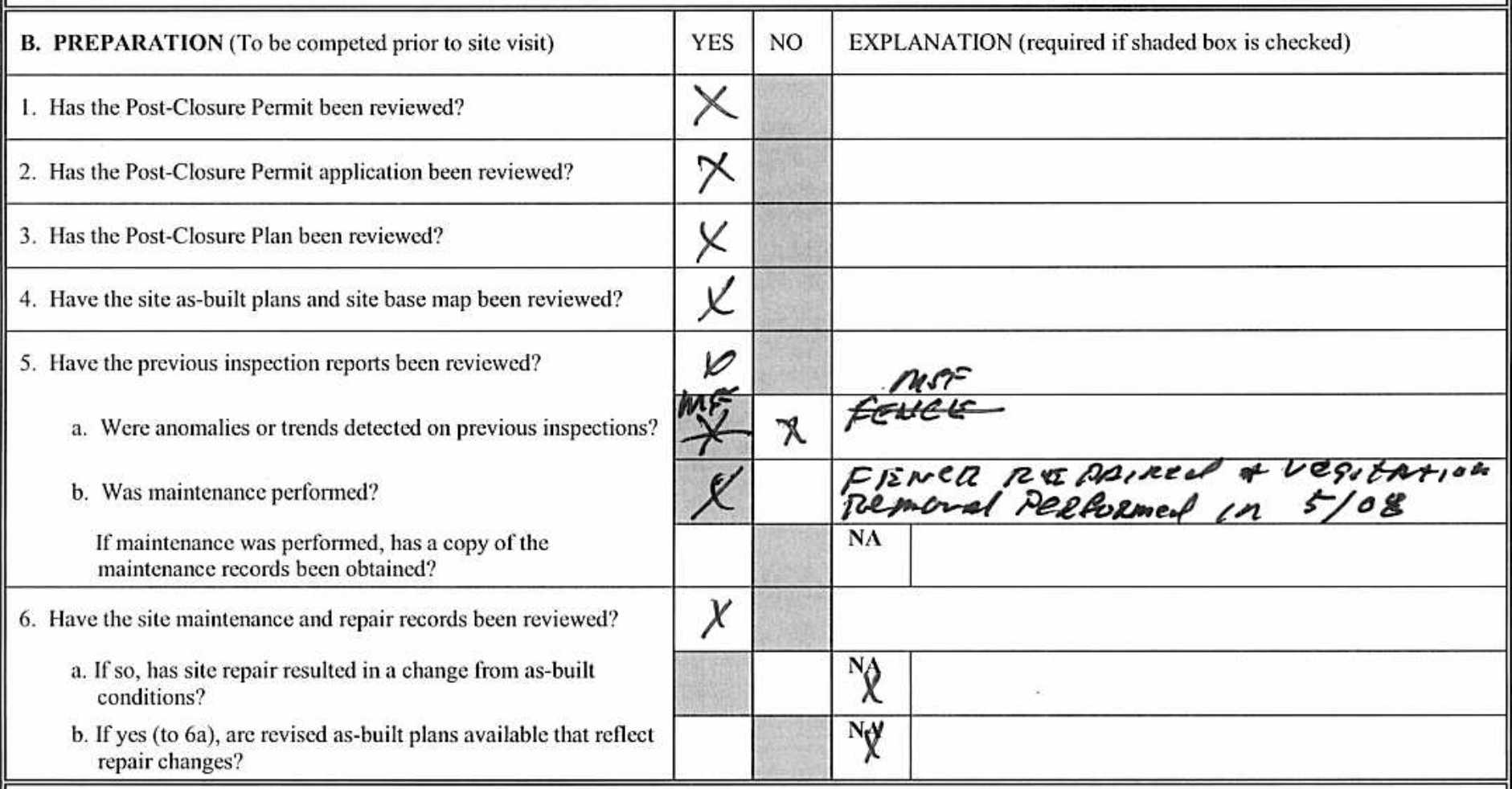

\section{SITE INSPECTION PREPARATION}

Assemble the following, as needed, to conduct inspections
a. Camera, film, and batteries
e. Radio, pager, etc.
b. Keys to locks
c. Clipboard
. Previous Post-Closure Report, Inspection Checklists, repair records, and as-built plans
g. Other miscellaneous support equipment

d. Tape measure 


\section{POST-CLOSURE INSPECTION CHECKLIST}

CAU 112: AREA 23 HAZARDOUS WASTE TRENCHES - CAS 23-21-02: Area 23 Haz. Waste Trenches (RCRA)

\section{SITE INSPECTION}

1. Adjacent off-site features:

a. Are there any new activities or features in the vicinity that could potentially affect the site (e.g., activities that change the flow of surface water or are encroaching the unit)?

2. Fences, gates, and signs (East Fenced Enclosure):

a. Is there damage to or a break in the fence?

b. Have any fenceposts been damaged or their anchoring weakened?

c. Is the gate intact and functional?

d. Does the gate show evidence of tampering or damage?

e. Was the gate locked?

f. Are any of the use restriction signs damaged or missing?

g. Are all use restriction signs legible?

h. How many use restriction signs need to be replaced?

i. Other?

3. Monuments:

a. Have landfill monuments been disturbed?

b. Do natural processes threaten the integrity of any landfill monuments?

c. Is there excessive vegetation around the landfill monuments?

d. Other?

4. Waste unit cover:
a. Is there evidence of settling?
b. Is there evidence of cracking?
c. Is there evidence of erosion (wind or water)?
d. Is there evidence of human intrusion onto the cover?
c. Is there evidence of large animal intrusion onto the cover?
f. Is there evidence of animal burrowing?
g. Is vegetation growing on the cover?
h. Other (including trash, debris, etc within fenced area)?

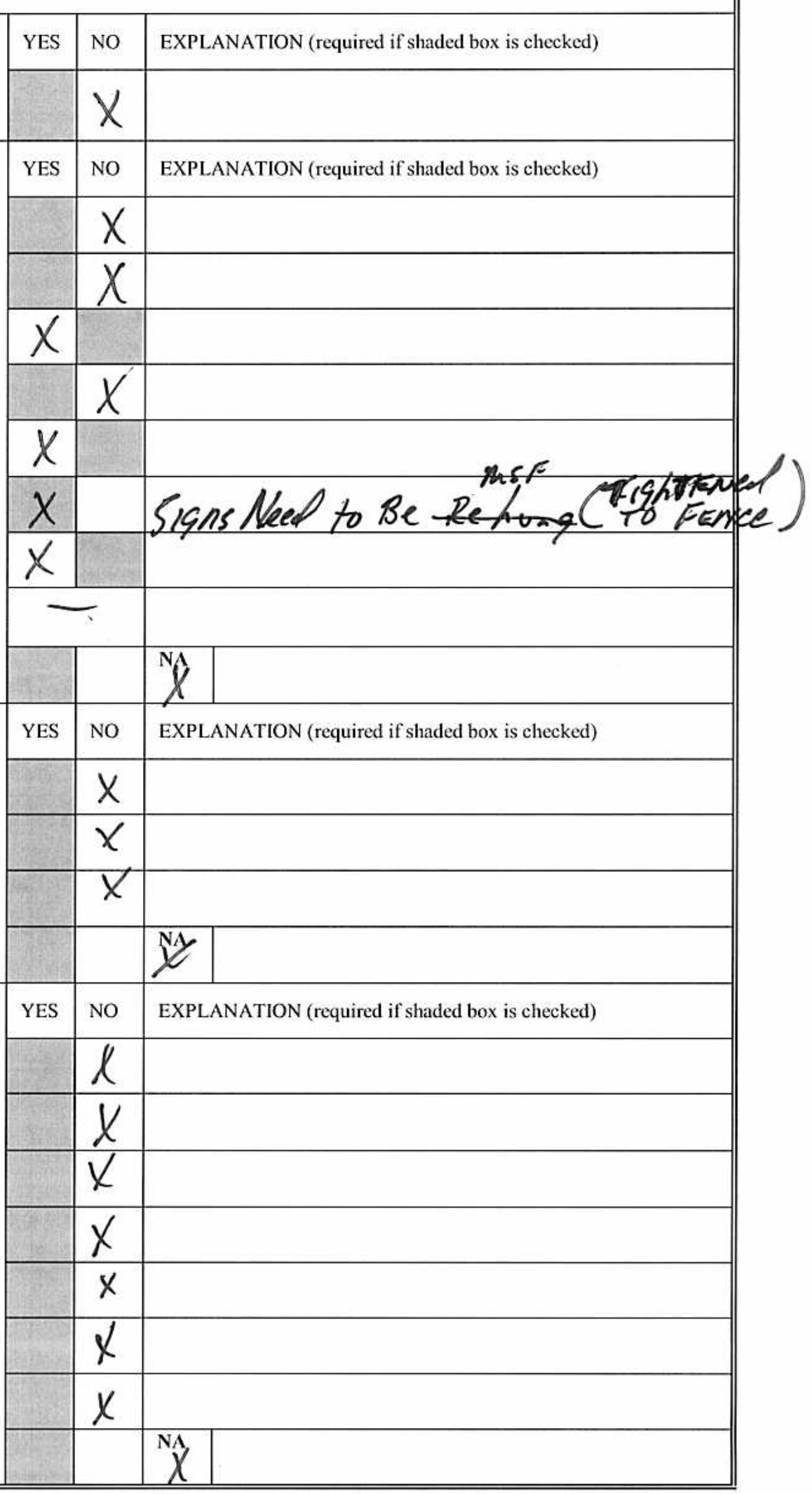




\section{POST-CLOSURE INSPECTION CHECKLIST}

\section{CAU 112: AREA 23 HAZARDOUS WASTE TRENCHES - CAS 23-21-02: Area 23 Haz. Waste Trenches (RCRA)}

5. Photograph Documentation (optional):

a. Have photographs been taken of the site?

If yes, how many photos were taken?

If yes, has a photographic log been prepared?

\section{E. FIELD CONCLUSIONS}

1. Are more frequent inspections required?

2. Are existing maintenance/repair actions satisfactory?

3. Is other maintenance/repair necessary?

4. Is there an imminent hazard to the integrity of the site? (Immediate report required)

\begin{tabular}{|c|c|l|}
\hline YES & NO & EXPLANATION \\
\hline & X & \\
\hline & & \\
\hline & & Log number: \\
\hline YES & NO & EXPLANATION (required if shaded box is checked) \\
\hline & $\chi$ & \\
\hline$\chi$ & & \\
& $X$ & \\
\hline & $\nearrow$ & \\
\hline
\end{tabular}

Date reported:

Person/Agency to whom report was made:

5. Field conclusions/recommendations: CAU $1 / 2$ was Found 70 be in good Coudation with the exception of 2 sighr found to Be loose on the North Fencee line. Hiese Signs whll Be tiglrenet to ye Finace.

\section{F. CERTIFICATION}

I have conducted an inspection of CAU 112, Area 23 Hazardous Waste Trenches, in accordance with the procedures of the Post-Closure Permit (including the Post-Closure Plan) as recorded on this checklist, atterched sheets, and field notes.

Chief Inspector's Signature:

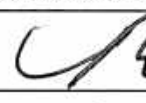

Printed Name:

Attachments (check if attached):

$\square$ Field Notes

$\square$ Maintenance records 


\section{POST-CLOSURE INSPECTION CHECKLIST}

\section{CAU 112: AREA 23 HAZARDOUS WASTE TRENCHES - CAS 23-21-02: Area 23 Haz. Waste Trenches (RCRA)}

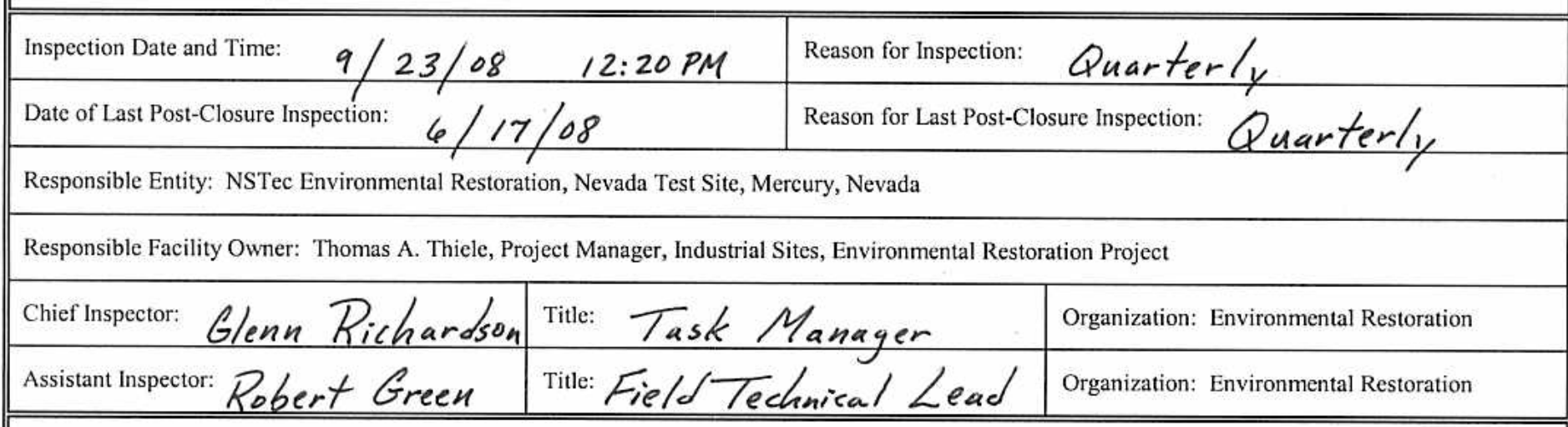

\section{A. GENERAL INSTRUCTIONS}

1. All checklist items must be completed and detailed comments made to document the results of the site inspection. The completed checklist is part of the field record of the inspection. Additional pages should be used as necessary to ensure that a complete record is made. Attach the additional pages and number all pages upon completion of the inspection.

2. Any checklist line item marked by an inspector in a SHADED BOX must be fully explained or an appropriate reference to previous reports provided. The purpose of this requirement is to provide a written explanation of inspector observations and the inspector's rationale for conclusions and recommendations. Explanations are to be placed on additional attachments and cross-referenced appropriately. Explanations, in addition to narrative, will take the form of sketches, measurements, and annotated site maps.

3. The site inspection is a walking inspection of the entire site including the perimeter and sufficient transects to be able to inspect the entire surface and all features specifically described in this checklist.

4. Field notes taken to assist in completion of this checklist will become part of the inspection record. No form is specified for field notes; however, they must be legible and in sufficient detail to enable review by succeeding inspectors and the responsible agency.

5. This unit will be inspected quarterly with formal reporting to the Nevada Division of Environmental Protection to be done annually. The annual report will include an executive summary, this inspection checklist with field notes attached, and recommendations and conclusions.

B. PREPARATION (To be competed prior to site visit)

1. Has the Post-Closure Permit been reviewed?

2. Has the Post-Closure Permit application been reviewed?

3. Has the Post-Closure Plan been reviewed?

4. Have the site as-built plans and site base map been reviewed?

5. Have the previous inspection reports been reviewed?

a. Were anomalies or trends detected on previous inspections?

b. Was maintenance performed?

If maintenance was performed, has a copy of the maintenance records been obtained?

6. Have the site maintenance and repair records been reviewed?

a. If so, has site repair resulted in a change from as-built conditions?

b. If yes (to 6a), are revised as-built plans available that reflect repair changes?

Sign maintenance and fence repair activities were completed on $8 / 7 / 08$. NA Maintenance records are kept in an electronic database for Solid Waste maintenance services.

\section{SITE INSPECTION PREPARATION}

Assemble the following, as needed, to conduct inspections:
a. Camera, film, and batteries
e. Radio, pager, etc.
b. Keys to locks
c. Clipboard
f. Previous Post-Closure Report, Inspection Checklists, repair records, and as-built plans
g. Other miscellaneous support equipment

d. Tape measure 


\section{POST-CLOSURE INSPECTION CHECKLIST}

\section{CAU 112: AREA 23 HAZARDOUS WASTE TRENCHES - CAS 23-21-02: Area 23 Haz. Waste Trenches (RCRA)}

\section{SITE INSPECTION}

1. Adjacent off-site features:

a. Are there any new activities or features in the vicinity that could potentially affect the site (e.g., activities that change the flow of surface water or are encroaching the unit)?

2. Fences, gates, and signs (East Fenced Enclosure):

a. Is there damage to or a break in the fence?

b. Have any fenceposts been damaged or their anchoring weakened?

c. Is the gate intact and functional?

d. Does the gate show evidence of tampering or damage?

e. Was the gate locked?

f. Are any of the use restriction signs damaged or missing?

g. Are all use restriction signs legible?

h. How many use restriction signs need to be replaced?

i. Other?

3. Monuments:

a. Have landfill monuments been disturbed?

b. Do natural processes threaten the integrity of any landfill monuments?

c. Is there excessive vegetation around the landfill monuments?

d. Other?

4. Waste unit cover:

a. Is there evidence of settling?

b. Is there evidence of cracking?

c. Is there evidence of erosion (wind or water)?

d. Is there evidence of human intrusion onto the cover?

e. Is there evidence of large animal intrusion onto the cover?

f. Is there evidence of animal burrowing?

g. Is vegetation growing on the cover?

h. Other (including trash, debris, etc within fenced area)?

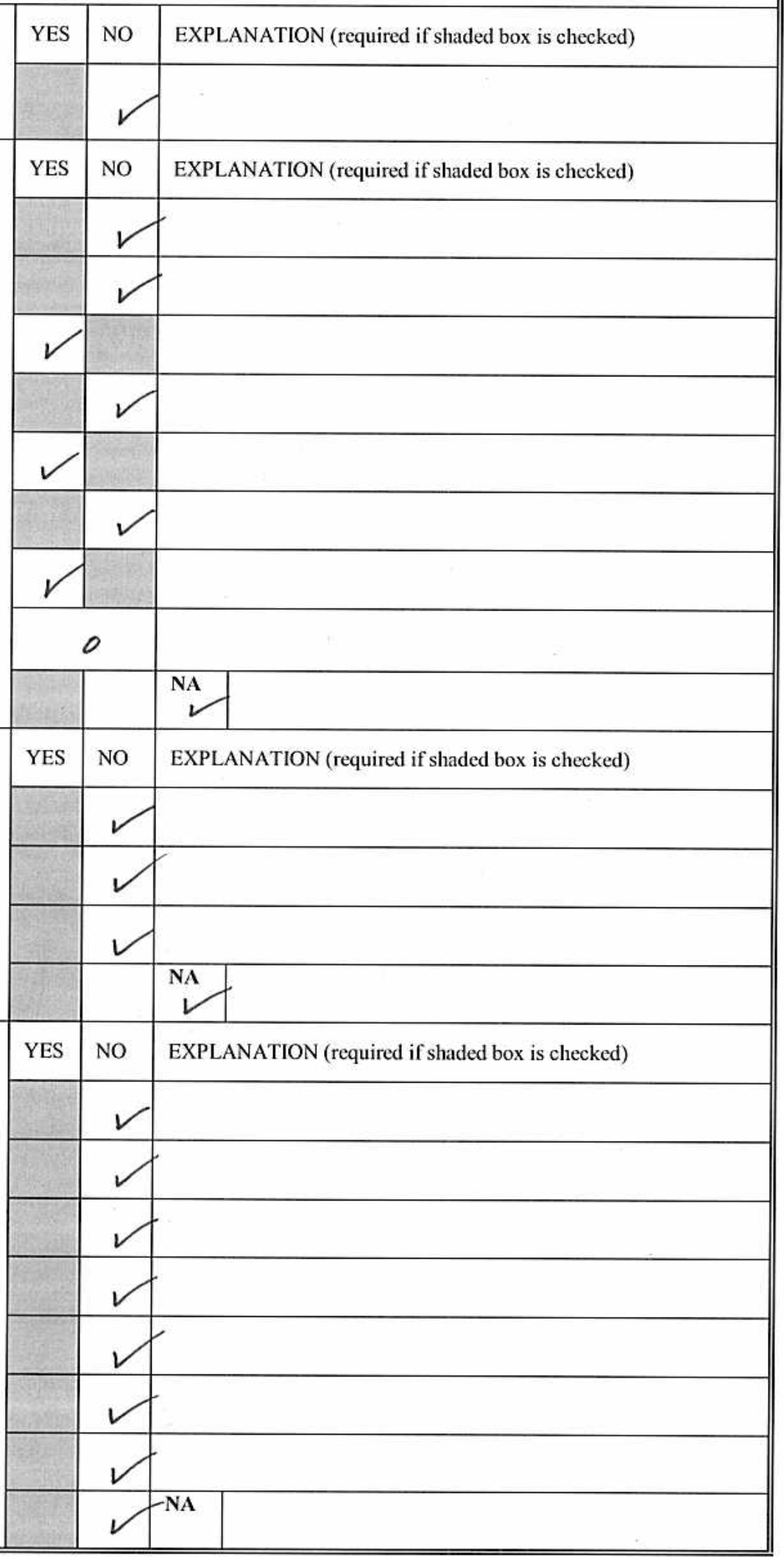




\section{POST-CLOSURE INSPECTION CHECKLIST}

\section{CAU 112: AREA 23 HAZARDOUS WASTE TRENCHES - CAS 23-21-02: Area 23 Haz. Waste Trenches (RCRA)}

5. Photograph Documentation (optional):

a. Have photographs been taken of the site?

If yes, how many photos were taken?

If yes, has a photographic log been prepared?

\section{E. FIELD CONCLUSIONS}

1. Are more frequent inspections required?

2. Are existing maintenance/repair actions satisfactory?

3. Is other maintenance/repair necessary?

4. Is there an imminent hazard to the integrity of the site? (Immediate report required)

\begin{tabular}{|l|l|l|}
\hline YES & NO & EXPLANATION \\
\hline & & Photos are not required for CAU IIZ. \\
\hline & $N / A$ & \\
\hline YES & NO & EXPLANATION (required if shaded box is checked) \\
\hline & & \\
\hline & & \\
\hline
\end{tabular}

Date reported:

Person/Agency to whom report was made:

5. Field conclusions/recommendations: The UR signage, fencing, and a boveground monuments are in excellent condition. No evidence of vegetation on top of the rip rap cover. There are no issnes at this site.

\section{F. CERTIFICATION}

I have conducted an inspection of CAU 112, Area 23 Hazardous Waste Trenches, in accordance with the procedures of the Post-Closure Permit (including the Post-Closure Plan) as recorded on this checklist, attached sheets, and field notes.

Chief Inspector's Signature:

Attachments (check if attached):

$\square$ Field Notes

$\square$ Maintenance records 
RCRA Post-Closure Report

Revision: 0

Date: December 2008

\section{ApPendix B.}

\section{FIELD NOTES}


RCRA Post-Closure Report

Revision: 0

Date: December 2008

THIS PAGE INTENTIONALLY LEFT BLANK 
RCRA Post-Closure Report

Revision: 0

Date: December 2008

\section{DECEMBER 18, 2007}


RCRA Post-Closure Report

Revision: 0

Date: December 2008

THIS PAGE INTENTIONALLY LEFT BLANK 
PROJECT NO.

169

TITLE

BOOK NO.

Work continued from Page

(CA492) Area 6 Deon Pond Precipitation Inspection $12 / 11 / 07$

Scope :

Arrived@1:07PM to inspect level of precipitation on the waste unit cover. Received an email notification from the UCC MEDA Station 5 that the level of precipitation exceeded our regulatory threshold of $0.5 \mathrm{in}$ on $12 / 8 / 07$ (Saturday). The precipitation event reached a level of $0.8 \mathrm{in}$.

Personnel: Glenn Richardson, Task Manager Equipment: Camera, Radio 10 Dudley Ever, Sr. Scientist

Performed a site walk down around the Deon Pond fenced area. Noticed standing water inside the NE comer of the fenced area, but was not observed on the waste unit cover. The fencing and UR signage is in good condition, 15 Also, the wave barriers are not damaged and appear to be maintaining their stability. The site is in great condition and was not adversely affected by the precipitation event. There are no issues or Concerns associated with this site. Leaving the site at H.23PM

20

RCRA Post Closure Inspections - December 18, 2007

25

Personnel: Glenn Kichardson-NSTec Task Mgr. Dudley Ever - NSTec Senior Scientist, Greg Doyle-NSTec Engine
Geologic:

Visitors: Ted Zaferatos - NDEP

Kevin Coble, Janis Rom - NNSA

SCIENTIFIC BINDERY PRODUCTIONS CHICAGO 60605 Made in USA

Work continued to Page 170

SIGNATURE

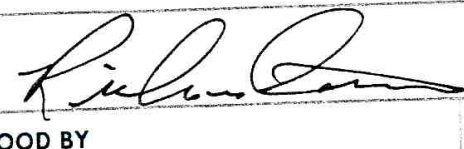

DATE

WITNESS

DATE

$12 / 18 / 07$

DISCLOSED TO AND UNDERSTOOD BY

DATE 
170

PROJECT NO.

BOOK NO.

Work continued from Page 169

Scope: Perform quarterly and semiannual post closure site inspections for the following CAUs: $90,92,110,+112$

Equipment: Camera

Weather Conditions: Cloudy, Extremely Low -Mid 30 's

PPE: Standard Level $D$ (hard hats are optional)

8:55 AM- Left Mercury in Route to Area 2 Bitcutter Site 9:384M-Arrived @ CAn 90 Bitcutter

Performed a Tailgate Safety Briefing $w / N N S A+N D E P$.

- Discussed Cold Stress conditions, Slips/trips/fall hazards

- "balanced consumption of water to prevent dehydration

- "buddy system during walkdown

9:45 AM - Performed site inspection $\subseteq$ CAU 90. Overall site conditions are good. There are no signs of vegetation growth. The chain link fencing and signage are in good condition. Noticed a small animal burrow inside the west fenced areas however, this not significant enough to warrant a corrective action. $9: 54 \mathrm{AM}$ - Leaving CAU 90 in route to CAM $110 \mathrm{U3ax/b/.}$ 10:10AM-Arrived@CAn110 and started site inspection. Greg Doyle met us at the site and participated in the site inspection. The fencing and signage looked good and was well -maintained. There were a few animal burrows identified. A followup action will be taken to contact $D$. Anderson (ecological services) to plan a sitevisitior to the March inspection period. We also discovered a new crack greater than 6 ft. on the surface (lateral extent) on the east edge of the cover. Photos were taken for documentation and repair is necessary within 60 days. After discussing our observations CIENTIFIC BINDERY PRODUCTIONS CHICAGO 60605 Made in USA

Work continued to Page $17 /$

SIGNATURE

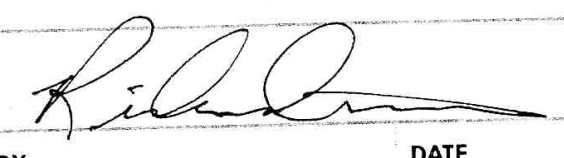

DATE

DISCLOSED TO AND UNDERSTOOD BY

DATE

WITNESS

$12 / 18 / 07$ 
PROJECT NO.

171

TITLE

BOOK NO.

Work continued from Page 170

with NNSA and NDEP, we departed the site in route to CAU92. Greg Doyle returned to Mercury after the 110 inspection.

11:18AM-Arrived@CAU 92 and performed site inspection.

Overall site conditions are great. The fencing and $U R$ signage 5 are well maintained. No evidence of vegetation growth. The wave barriers are not damaged. Photo documentation was taken at this site. No issues or concerns. Lett CAL 92 in route to CAU 112 .

12:02 PM-Arrived @ CAU $/ 12$ and performed a site inspection. 10 Drove around Area 23 waste trenches to find no

observations that warranted a corrective action. The URsignsand aboveground monuments are in good condition. No evidence of vegetation growth. Left CAUIIZ and headed to ER Dorms.

12:10 PM - Debrief of all observations was discussed w/NNSA 15 and NDEP. NNSA + NDEP left the dorms in route to Mercury. End of Inspections at 12:15 PM.

Note: Photosthwere taken will be 10 ged on the ER Shared Drive.

20

Sher

25

SCIENTIFIC BINDERY PRODUCTIONS CHICAGO 60605 Made in USA

SIGNATURE

DISCLOSED TO AND UNDERSTOOD BY
Work continued to Page

DATE

$12 / 18 / 07$ 
RCRA Post-Closure Report

Revision: 0

Date: December 2008

THIS PAGE INTENTIONALLY LEFT BLANK 
RCRA Post-Closure Report

Revision: 0

Date: December 2008

\section{MARCH 26, 2008}


RCRA Post-Closure Report

Revision: 0

Date: December 2008

THIS PAGE INTENTIONALLY LEFT BLANK 
174 TITLE

Work continued from Page
PROJECT NO.

BOOK NO.

RCRA Post Closure Inspections - March 26, 2008

Personnel: Glenn Richardson - NATe Task Manager

Greg Doyle - NSTec Engineering Geologist / Pleven Perez

5

Mike Floyd ER - NSTec Field Technical Lead Lead RCT

Visitors: Ted Zafcratos - NDEP

Kevin Cable - NNSA

Scope: Perform quarterly and semiannual post closure site

10 inspections for the following CAUS: 91, 92, 110, and 112

Equipment: Camera, Measurement Ruler, Radiological Survey/Screening

Weather Conditions: Sunny, Low 50 s

PPE : Standard Level D

9:38AM- Left Mercury in Route to Area 3 43 35 ax /b! Injection be

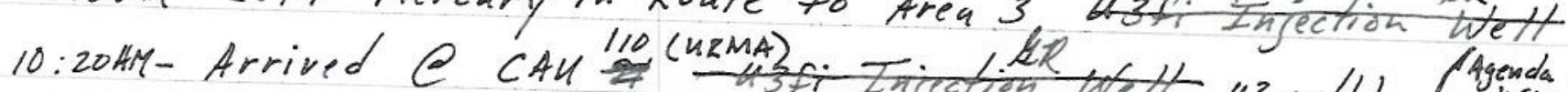
Performed a Tailgate Safety $B$.

20

- Discussed desert terrain and the potential for slips,

trips, and falls

- Biological hazards and being cognizant of surroundings.

- Making sure a balanced consumption of water is maintained.

- Be aware of potential heat stress conditions as the morning progresses

- Maintain the buddy system throughout the walk down

- Lastly, "when in doubt, ask the question"

SCIENTIFIC BINDERY PRODUCTiONS CHICAGO 60605 Made in USA

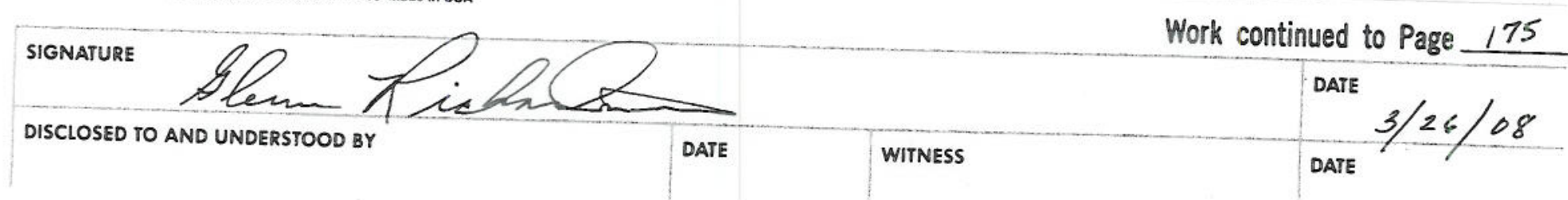


TITLE

Work continued from Page 174
PROJECT NO.

BOOK NO.

175

Performed site walk down of $43 \mathrm{ax} / \mathrm{bl}$. The most recent subsidence repair areas were observed and determined stable and in good condition. There were no new cracks or settling imperfections discovered by the engineering representative or walk down group. The vegetation was mature in growth ard the signage and fencing were in good condition. The white snow fencing at the initial entrance showed signs of degrading over time, but still maintained a physical barrier at the site. No corrective actions are necessary at this time, but a more durable fence could be considered as a best management practice in the near future. There was evidence of animal burrowing noticed in clustered areas; however, no immediate actions were warranted. Instead, the ecological services organization will be contacted to confirm their schedule for performing small mammal trapping activities prior to the next inspection period in June 2008. There were no issues or concerns identified by NNSA or NDEP that warranted an immediate followup action. (Note: Upon arrival at uzax/b), we were greeted by a geologist tour group, but their presence did not interfere or affect the inspection of the engineered cover.) 11:05 AM - Leaving 43 ax/b/ in route to CAU91.

11:10 AM - Arrived $C$ CAM al Area 3 u3fi Injection Well Performed our inspection of the site. The signage and fencing were in good condition. There was no evidence of animal burrowing at the site. Noticed a large amount of vegetation that had grown within the last 6-month period. Vegetation removal is necessary within 60 days. Also, herbicide will be sprayed to prevent vegetation growth in the future.

CIENTIFIC BINDERY PRODUCTIONS CHICAGO 60605 Made in USA Work continued to Page

SIGNATURE

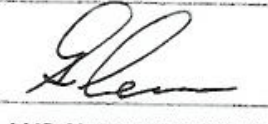

DISCLOSED TO AND UNDERSTOOD BY

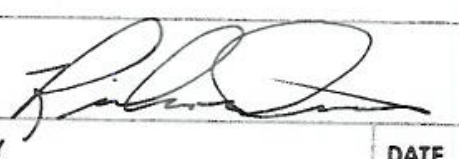

DATE

DATE

WITNESS

$3 / 26 / 08$ 
176 TITLE

Work continued from Page 175
PROJECT NO.

BOOK NO.

Photo documentation was forked taken as well.

II: 20 AM - Leaving $43 f_{i}$ in route to CAU 92.

11: 40 AM - Arrived C CAU 92 Deacon Pond - (URMA)

Performed our inspection of the site to find signage and

5

fencing in great condition. Also, the wave barriers were in good condition. There was no evidence of animal burrowing. Noticed small signs of vegetation starting to sprout on the cover. This site should be included in the list to receive weget action removal. Also, herbicide will be applied to the 10 site. Photo documentation was taken at the site as we 11.

12:00 PM - Leaving Decor Pond in route to CA4 112

12:28 PM - Arrived \& CAU112 Area 23 Hazardous Waste Trenches

Performed a drive around inspection of the site. Noticed one strand of barb wire loose on the east side of the fence. 15 In addition, noticed vegetation sprouting through the rip -rap on toper of the cover and the cover's slide slope. Barb wire will be replaced or repaired. Vegetation removal activities will be performed and barb wive fencing repaired within 60 days.

$20 \quad 12: 35 P M$ - Leaving $C 4 n 112$ for lunch. End of RCRA inspections.

Note: RCT coverage was provided for the RCRA Inspections as an ER BMP 25

ah. 
RCRA Post-Closure Report

Revision: 0

Date: December 2008

THIS PAGE INTENTIONALLY LEFT BLANK 
RCRA Post-Closure Report

Revision: 0

Date: December 2008

\section{JUNE 17, 2008}


RCRA Post-Closure Report

Revision: 0

Date: December 2008

THIS PAGE INTENTIONALLY LEFT BLANK 
TITLE

PROJECT NO. RCAN EuSPEAT6!

Work continued from Page $164 \quad 6 / 7 / 68$ BOOK NO.

1130 cour. - Spreayng w/thespiside po penswether in the

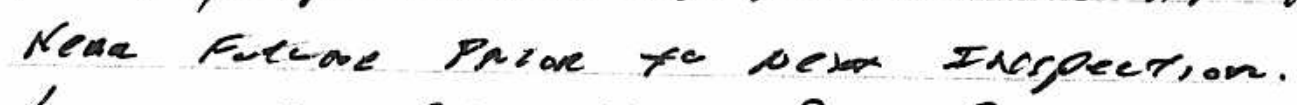

1155- heaung Con 92, Hend for Can 112

1220 - Arruve at care 112 . Fite was foumal to Be in

5 Good Conelition, 2 sigus on the worth sele were hoose nal need to kie pe strackele Bur ovexall site Gondition was bawd to be in gawe Condetern

1235- Reruen to Dorers

10

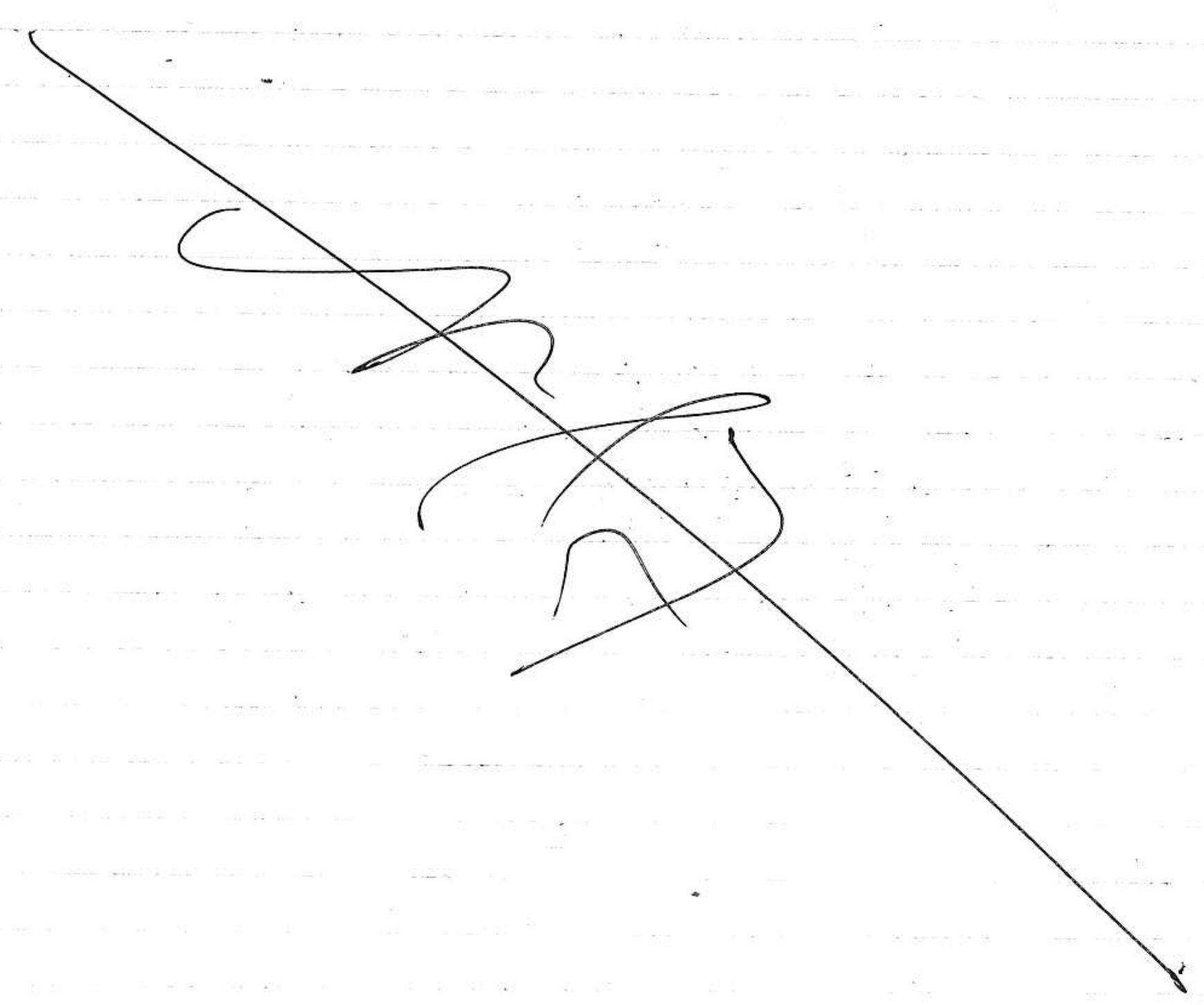

25

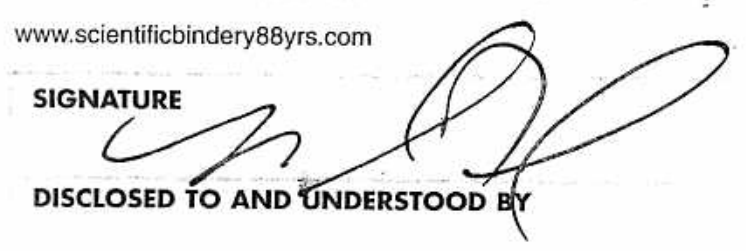

Work continued to Page

DATE

DATE 
RCRA Post-Closure Report

Revision: 0

Date: December 2008

\section{SEPTEMBER 23, 2008}


RCRA Post-Closure Report

Revision: 0

Date: December 2008

THIS PAGE INTENTIONALLY LEFT BLANK 
TITLE

PROJECT NO.

Work continued from Page

BOOK NO.

18

RCRA Post Closure Inspections - Sept. 23, 2008

Personnel: Glenn Richardson - NSTec Task Manager Robert Green - NSTec Field Technical Lead

$5 \quad$ Greg Doyle - NSTec Engineering Geologist

Visitors: Ted Zaferatos - NDEP

Kevin Gable - N NSA

Tom Thiele - NSTEC ER Project Manager

10 Scope: Perform quarterly PCM site inspections for the following CAus: 92, 110, and 112.

Perform semiannual PCM site inspection for CAC 91.

Equipment: Camera Weather Conditions: Sunny, Low pos

PPE: Standard Level D (no hard hats required)

9:28 AM - Leaving Mercury. (Dorm B) in route to Area 3 U3fi-Tinjection well. 10:10 AM -Arrived C CAu91-U3fi Injection Well

20 Performed a Tailgate Safety Briefing w/NNSA, $\epsilon$ DEP

- Discussed slips/trips and falls because of uneven desert terrain

- Be aware of biological hazards (ie. snakes, scorpions, etc.)

- Drink plenty of water to prevent dehydration

- Mentioned in case a fire started due to vehicle and dry brush, a

25 fine extinguisher was available in NoTe gout. vehicles Performed inspection of the U3fi site. The UR signs and chain link fencing were in excellent condition. No vegetation was inside the fenced area or a rand the concrete monument pad. No evidence

SCIENTIFIC BINDERY PRODUCTIONS CHICAgo 60005 Made in USA
SIGNATURE Work continued to Page 186

DISCLOSED TO AND UNDERSTOOD BY

DATE

WITNESS

DATE

$9 / 23 / 08$ 
186 TITLE

Work continued from Page 185
PROJECT NO.

BOOK NO.

of animal burrowing. The site was in excellent condition with no issues. Photo documentation was taken.

10:25 AM Leaving CAU 91 indonte to $43 a x / b /$ site.

10:324M Arrived @ CAL 110 u3ax/bl site. We met Greg Doyle at the site, went through a brief tailgate with Greg and accessed the site to perform our inspection. The vegetation on the cover appeared to be growing at a mature rate. Sima animal burrows were noticed, but nothing that warranted a follow-up action with our ecological services group. The subsidence repair areas on the east side of the landfill were inspected to find the repairs were in tact and wellmaintained. The survey markers appeared to be in good condition. A few small cracks were noticed, but were determined not to be significant enough to warrant 'a followup action. Well keep an eye on those areas during the next quarterly inspection in Dec. 2008. Overall site conditions were good. Photos were taken of the exterior and interior of the site. UR signs/fencing were great.

20 11:10 AM Leaving CAU IIO in route to Area 6 Decor Pond. We left Greg Doyle and Tom Thiele. Tom departed from the group to visit another $E R$ project.

11:304M Arrived $\mathrm{CAU} 92$ Decor Pond site. We did not access the site, but performed our inspection by driving around the chain link fenced area. Ono the east side of the fence, we

25 noticed a few wave barriers that contained open gaps. Photos were taken to document the need for repairs. The UR signs, rads and fencing were in great condition. Vegetation was noticed on the non the east perimeter of the cover. Also, dead vegetation

SCIENTIFIC BINDERY MATURE

Work continued to Page 187

DATE 
PROJECT NO.

BOOK NO.

187

Work continued from Page_ 186

was noticed on the noah edge of the cover that affected by herbicide application. There were no apparent signs of animal burrowing. Photos were taken of the exterior of the site. ER personnel will return/ater wan RCT as a BMP to retrieve photos inside the Decon Pond. NNSA and NDEP were interested why access was not allowed into the Deon Pond for this inspection. It was explained that even though the site is a URMA, it is not a rad con requirement to deny access without an RCT, but an ER internal policy that will be implemented due to recent radiological work control incidences. An email providing further clarification will be provided to NNSA and DEP.

11: SO AM Leaving CAU 92 in route to Area 23 Haze. Waste Trenches 12:20 M Arrived \& CAU IIL Hazardous Waste Trenches

Performed a drive around inspection to find no evidence of vegetation on the cover. The UR signage, aboveground monuments, and fencing are in excellent condition. There were no photos taken at this site as they are not required. There are no issues or follow-up actions required at this site.

12:28 PM Leaving CAU II Z for Inch. End of RCRA Inspections

Note: It was mentioned that all $U R$ signs will be replaced and upgraded to current guidance standards as a BMP.

Sham Rime

DISCLOSED TO AND UNDERSTOOD BY

Work continued to Page

sIGNATURE

DATE

DATE

WITNESS

DATE $9 / 23 / 08$ 
RCRA Post-Closure Report

Revision: 0

Date: December 2008

THIS PAGE INTENTIONALLY LEFT BLANK 
RCRA Post-Closure Report

Revision: 0

Date: December 2008

\section{Appendix C.}

\section{Photographs}


RCRA Post-Closure Report

Revision: 0

Date: December 2008

THIS PAGE INTENTIONALLY LEFT BLANK 


\section{Photograph Log}

\begin{tabular}{|c|c|c|c|}
\hline $\begin{array}{c}\text { CORRECTIVE } \\
\text { ACTION } \\
\text { UNIT } \\
\end{array}$ & DATE & $\begin{array}{c}\text { PHOTOGRAPH } \\
\text { NUMBER }\end{array}$ & DESCRIPTION \\
\hline \multirow{20}{*}{91} & \multirow{10}{*}{ 03/26/2008 } & 1 & Inside Facing North \\
\hline & & 2 & Inside Facing East \\
\hline & & 3 & Inside Facing South \\
\hline & & 4 & Inside Facing West \\
\hline & & 5 & Surface Monument Facing North \\
\hline & & 6 & Surface Monitoring Well Facing South \\
\hline & & 7 & Outside Facing North \\
\hline & & 8 & Outside Facing East \\
\hline & & 9 & Outside Facing South \\
\hline & & 10 & Outside Facing West \\
\hline & \multirow{10}{*}{$09 / 23 / 2008$} & 11 & Inside Facing North \\
\hline & & 12 & Inside Facing East \\
\hline & & 13 & Inside Facing South \\
\hline & & 14 & Inside Facing West \\
\hline & & 15 & Surface Monument Facing North \\
\hline & & 16 & Surface Monitoring Well Facing South \\
\hline & & 17 & Outside Facing North \\
\hline & & 18 & Outside Facing East \\
\hline & & 19 & Outside Facing South \\
\hline & & 20 & Outside Facing West \\
\hline \multirow[t]{11}{*}{92} & \multirow{8}{*}{ 03/26/2008 } & 21 & Inside Facing North \\
\hline & & 22 & Inside Facing East \\
\hline & & 23 & Inside Facing South \\
\hline & & 24 & Inside Facing West \\
\hline & & 25 & Outside Facing North \\
\hline & & 26 & Outside Facing East \\
\hline & & 27 & Outside Facing South \\
\hline & & 28 & Outside Facing West \\
\hline & \multirow[t]{3}{*}{$06 / 17 / 2008$} & 29 & Inside Facing North \\
\hline & & 30 & Inside Facing East \\
\hline & & 31 & Inside Facing South \\
\hline
\end{tabular}

This is a draft, predecisional U.S. Department of Energy document and is not releasable to the public. 


\section{Photograph Log, Continued}

\begin{tabular}{|c|c|c|c|}
\hline $\begin{array}{l}\text { CORRECTIVE } \\
\text { ACTION } \\
\text { UNIT } \\
\end{array}$ & DATE & $\begin{array}{c}\text { PHOTOGRAPH } \\
\text { NUMBER }\end{array}$ & DESCRIPTION \\
\hline & & 32 & Inside Facing West \\
\hline & & 33 & Outside Facing North \\
\hline & & 34 & Outside Facing East \\
\hline & & 35 & Outside Facing South \\
\hline & & 36 & Outside Facing West \\
\hline & \multirow{8}{*}{$09 / 23 / 2008$} & 37 & Inside Facing North \\
\hline & & 38 & Inside Facing East \\
\hline & & 39 & Inside Facing South \\
\hline & & 40 & Inside Facing West \\
\hline & & 41 & Outside Facing North \\
\hline & & 42 & Outside Facing East \\
\hline & & 43 & Outside Facing South \\
\hline & & 44 & Outside Facing West \\
\hline \multirow{8}{*}{110} & \multirow{8}{*}{ 09/23/2008 } & 45 & Inside Facing North \\
\hline & & 46 & Inside Facing East \\
\hline & & 47 & Inside Facing South \\
\hline & & 48 & Inside Facing West \\
\hline & & 49 & Outside Facing North \\
\hline & & 50 & Outside Facing East \\
\hline & & 51 & Outside Facing South \\
\hline & & 52 & Outside Facing West \\
\hline
\end{tabular}




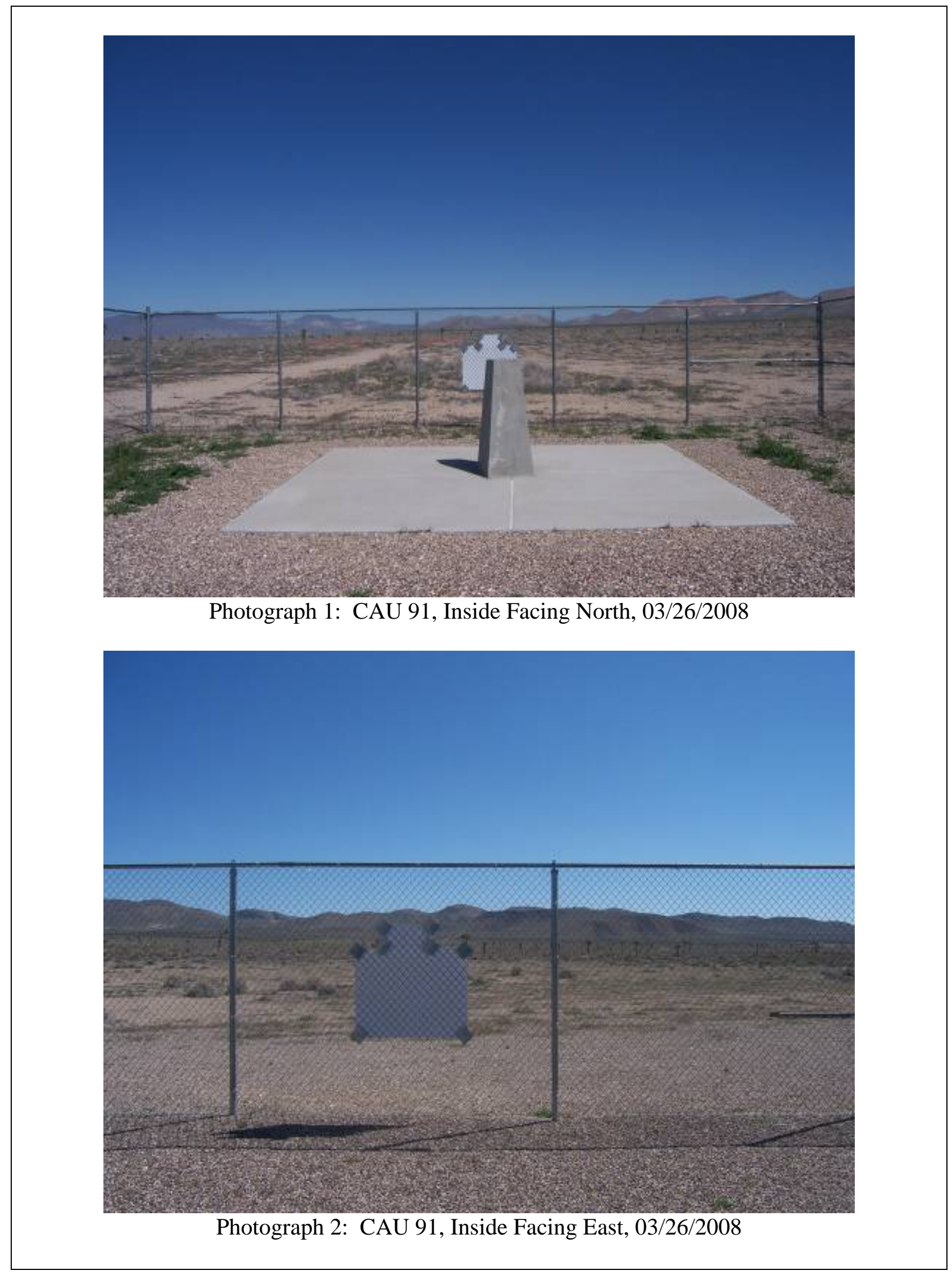




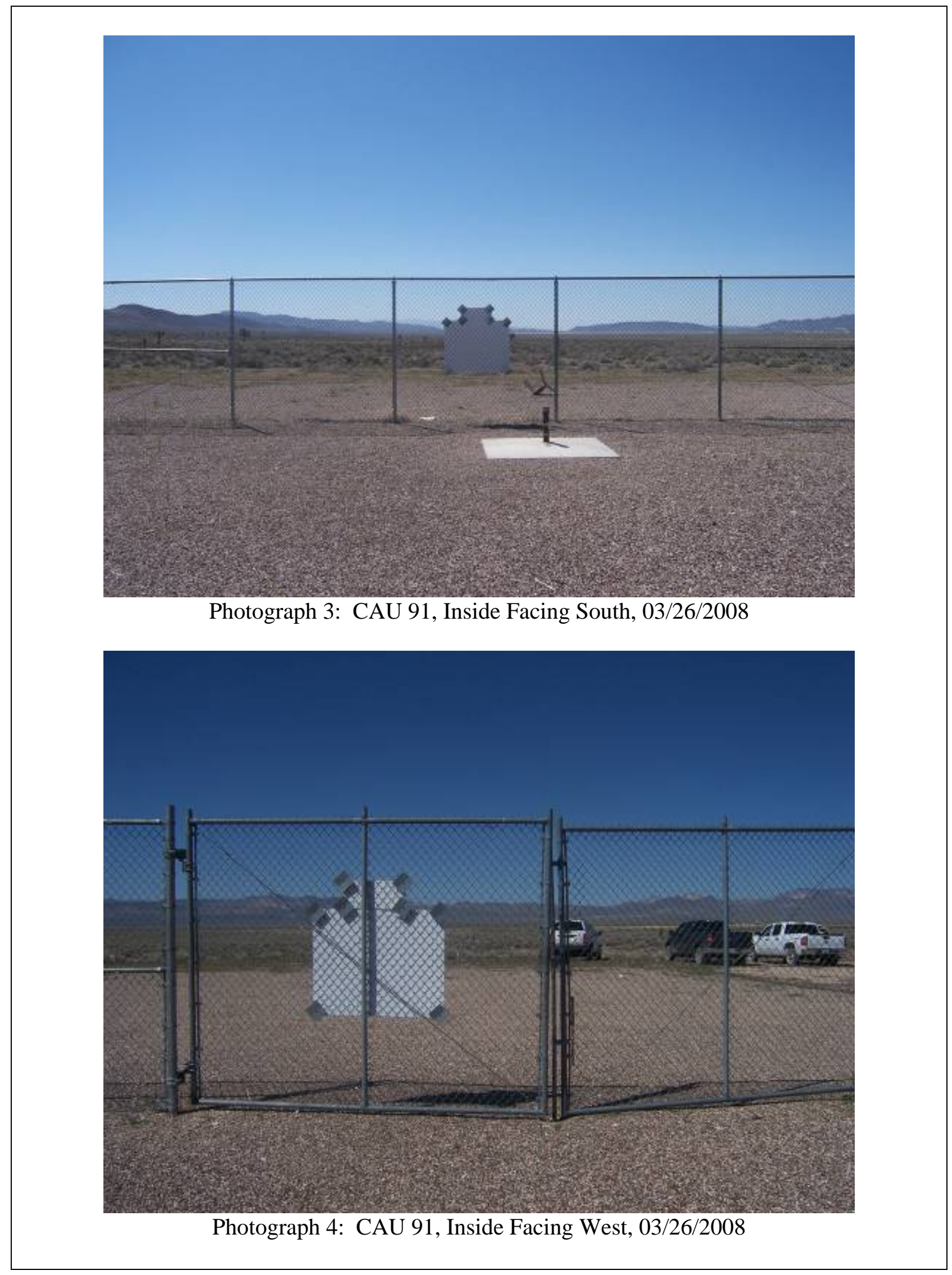




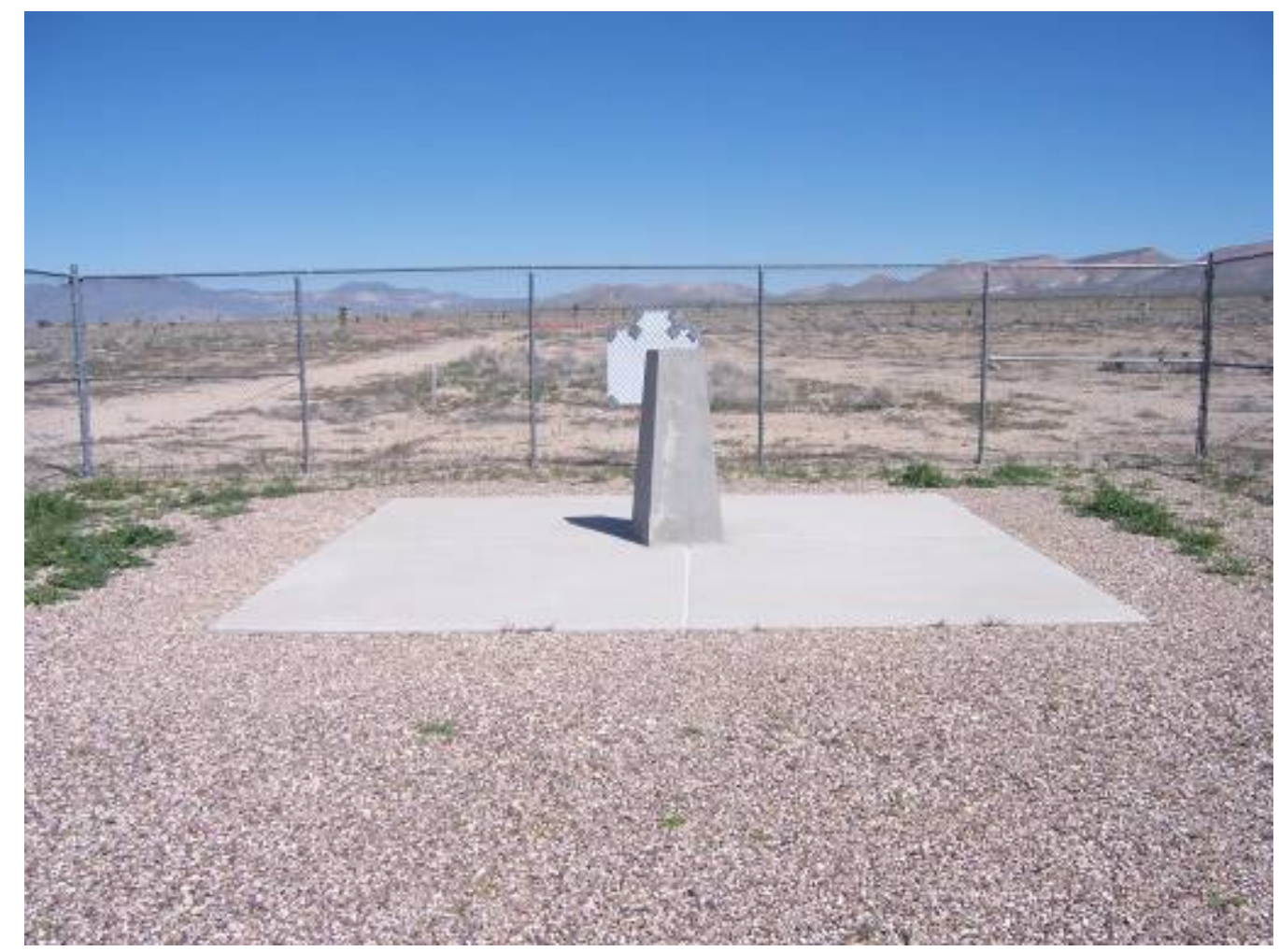

Photograph 5: CAU 91, Surface Monument Facing North, 03/26/2008

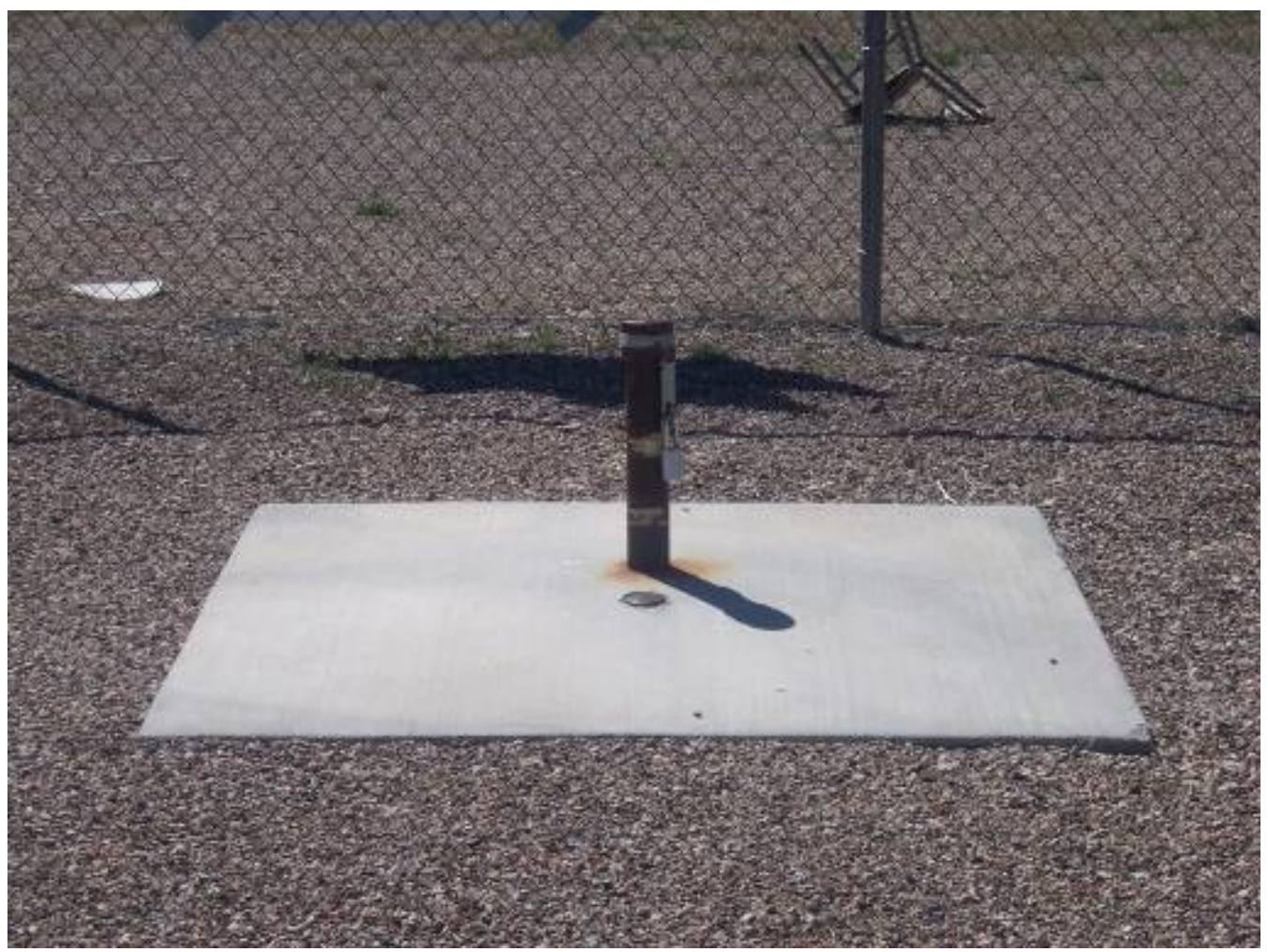

Photograph 6: CAU 91, Surface Monitoring Well Facing South, 03/26/2008 


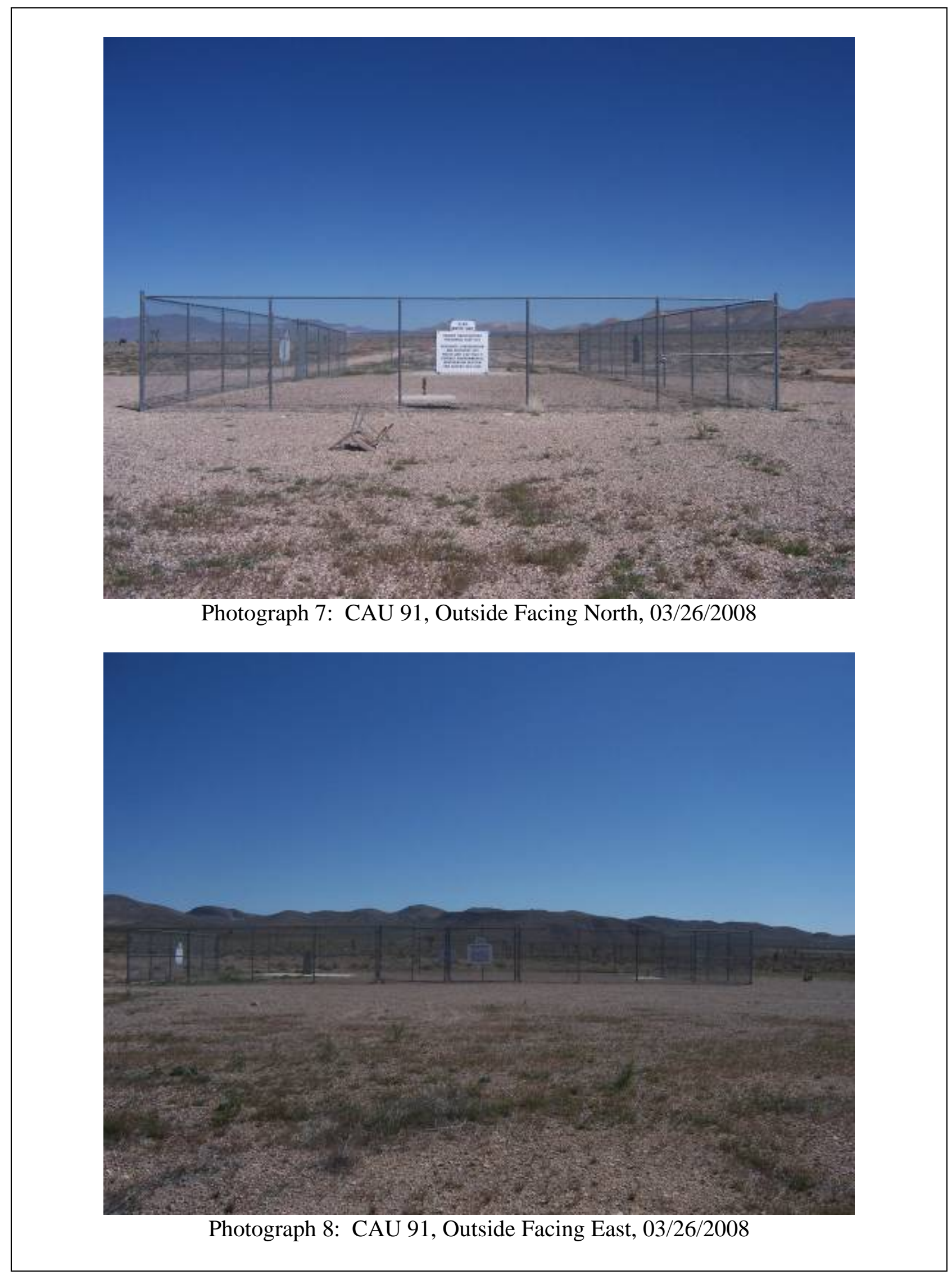




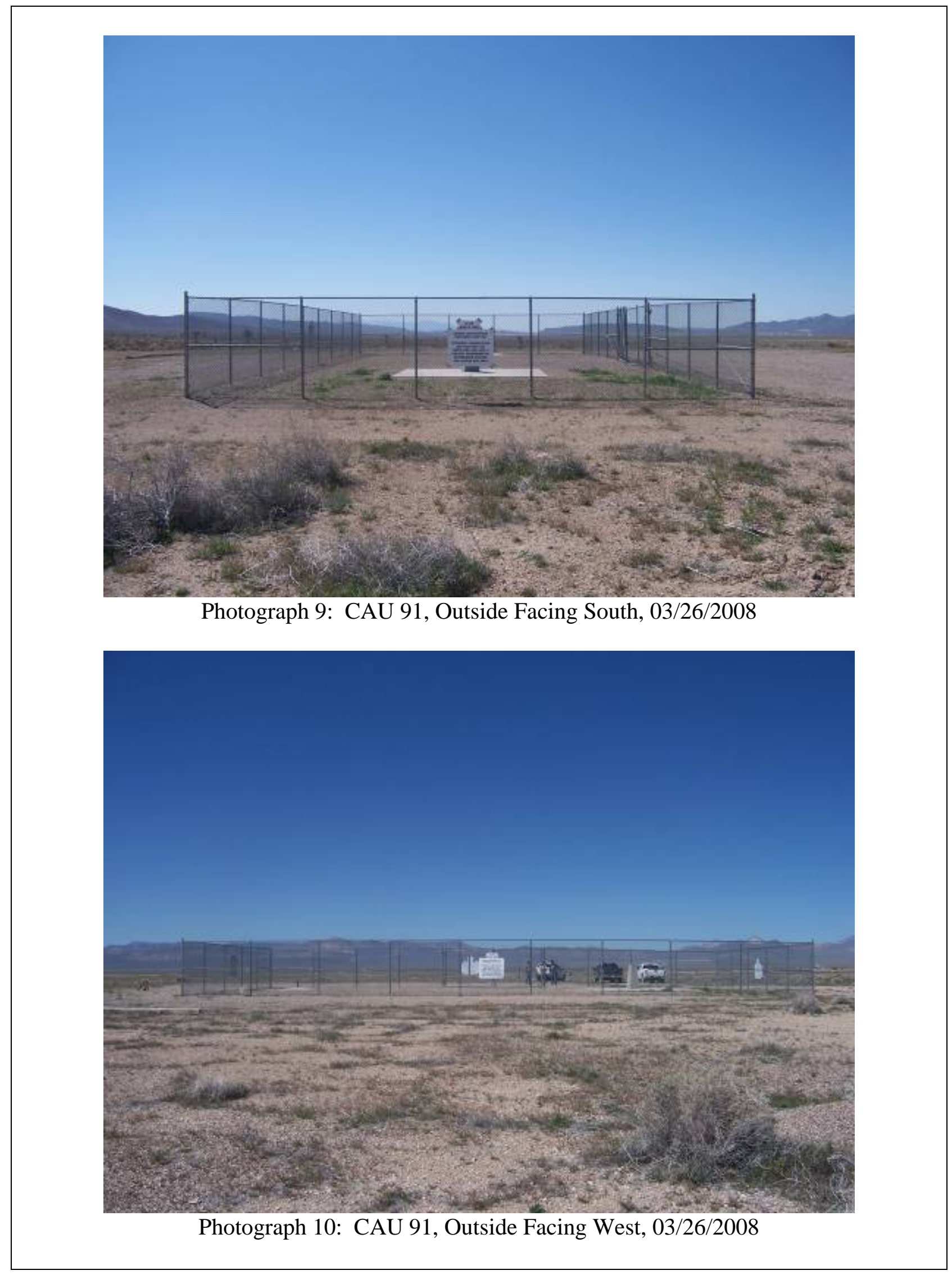




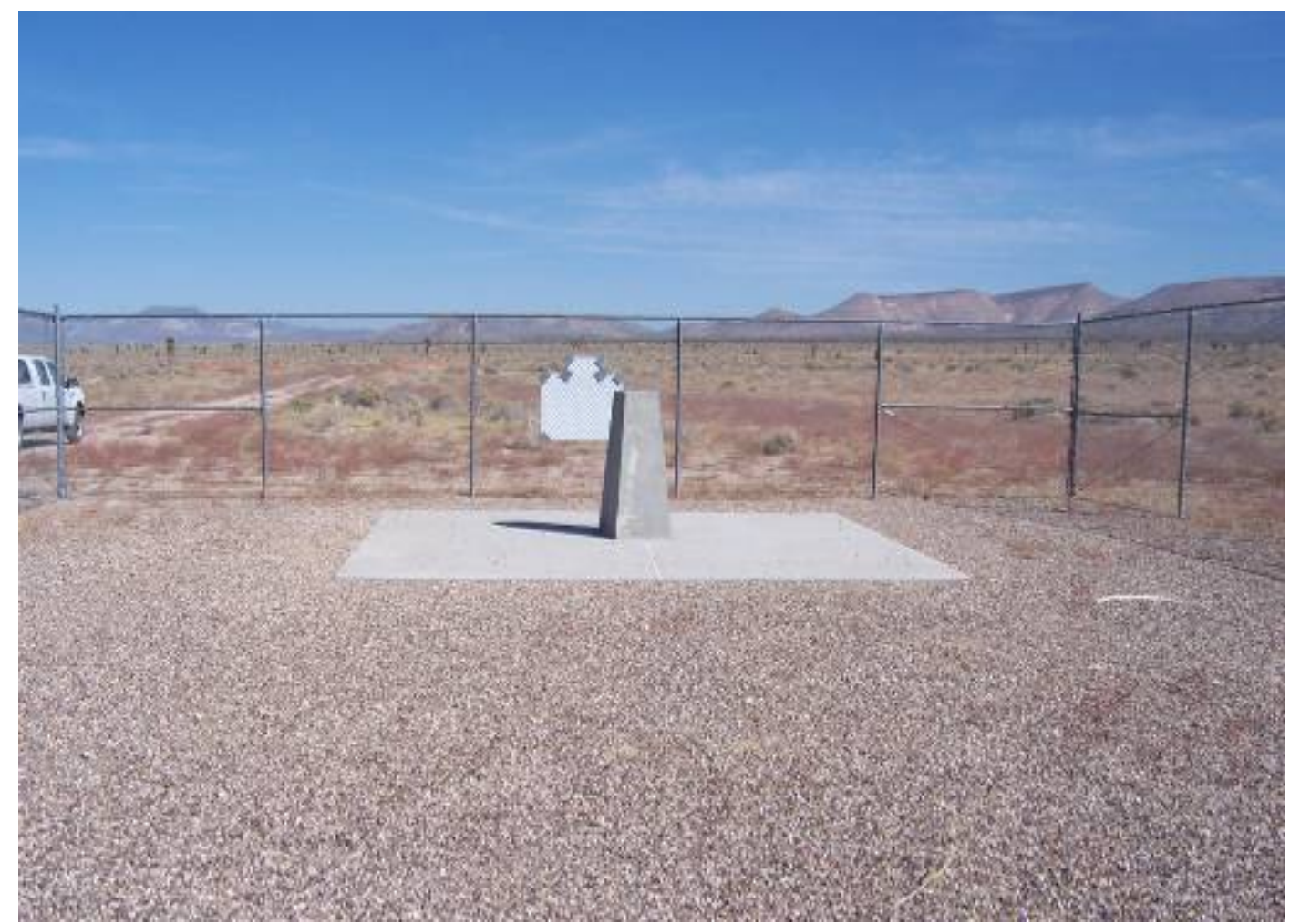

Photograph 11: CAU 91, Inside Facing North, 09/23/2008

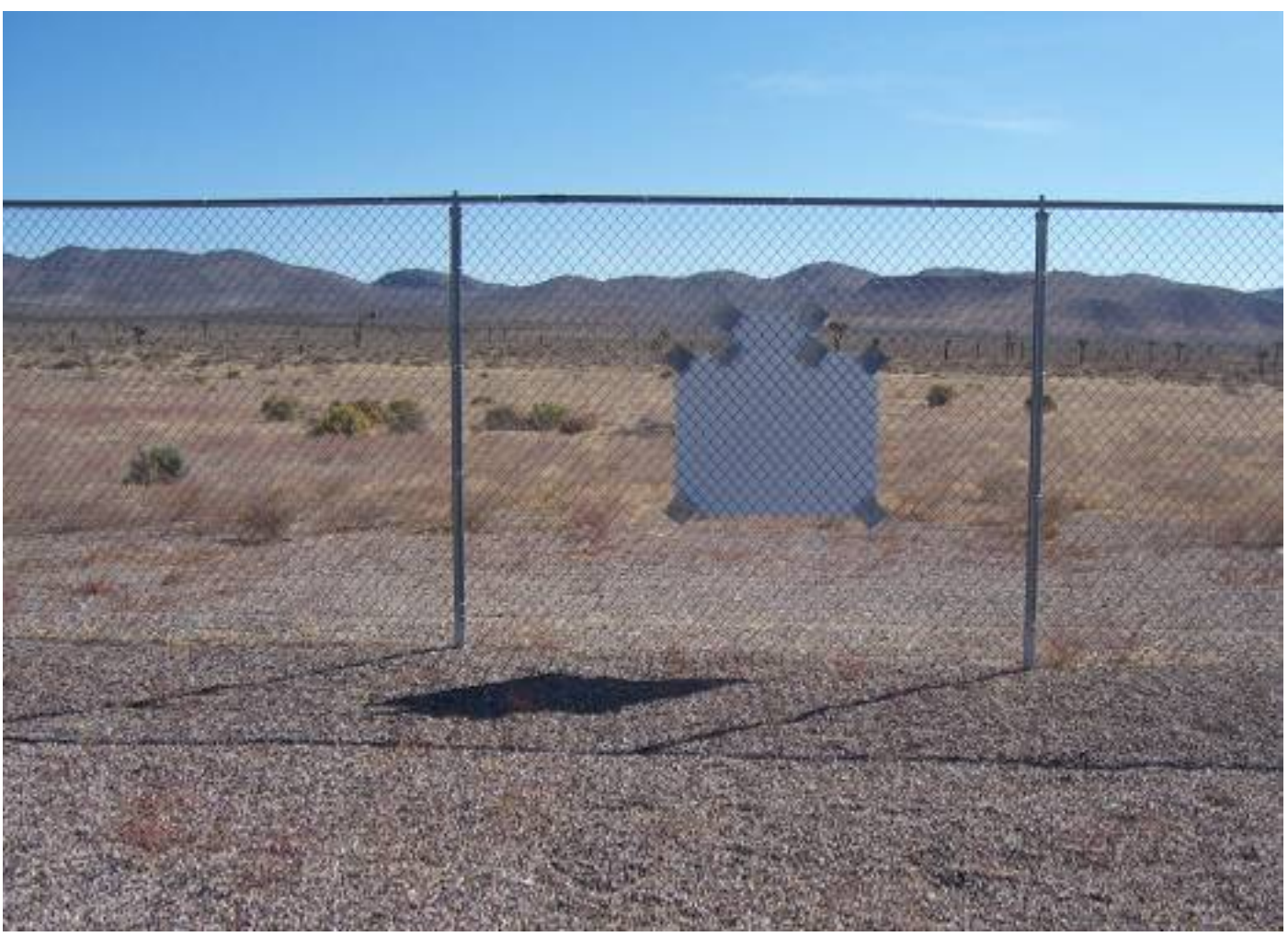

Photograph 12: CAU 91, Inside Facing East, 09/23/2008 


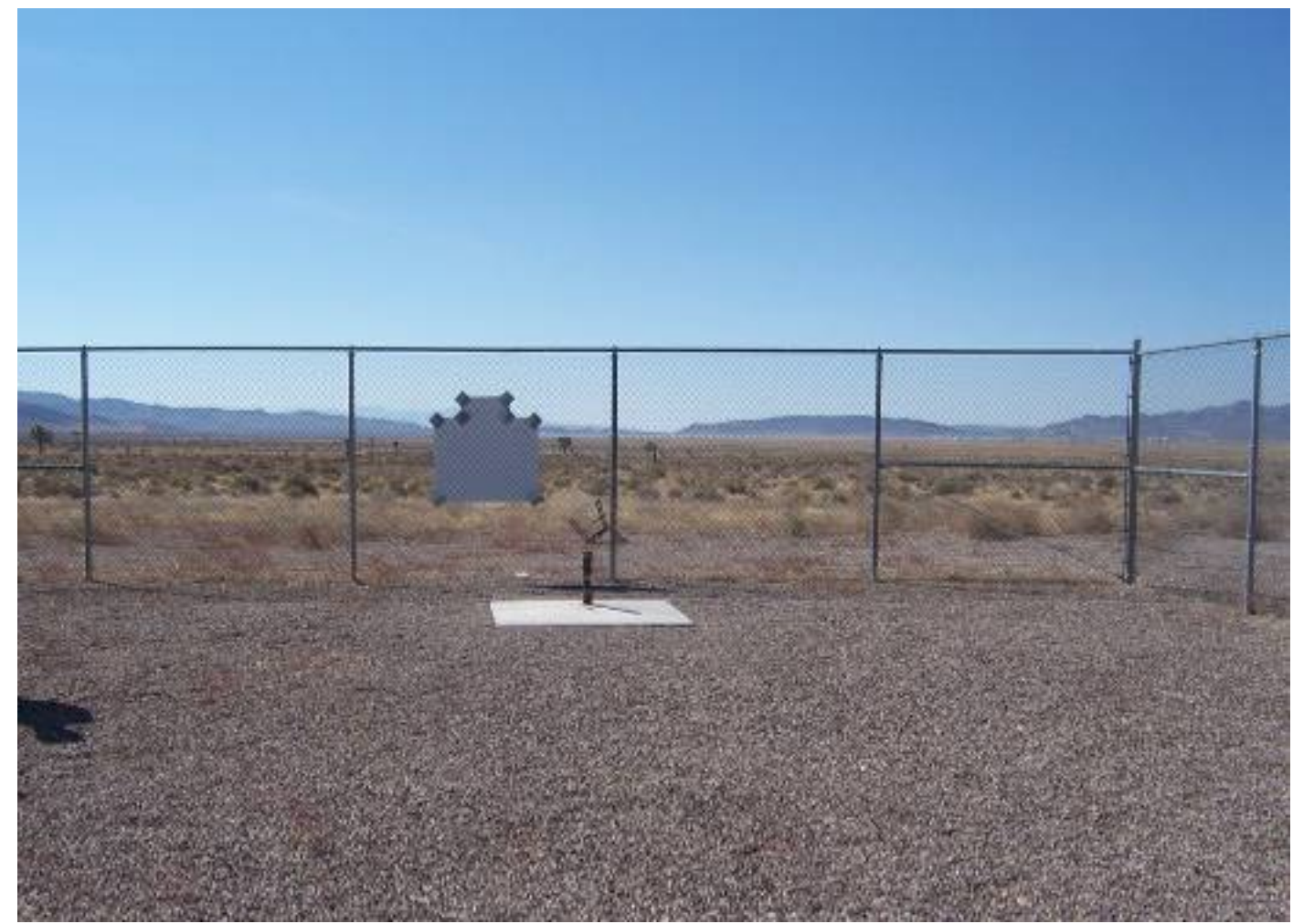

Photograph 13: CAU 91, Inside Facing South, 09/23/2008

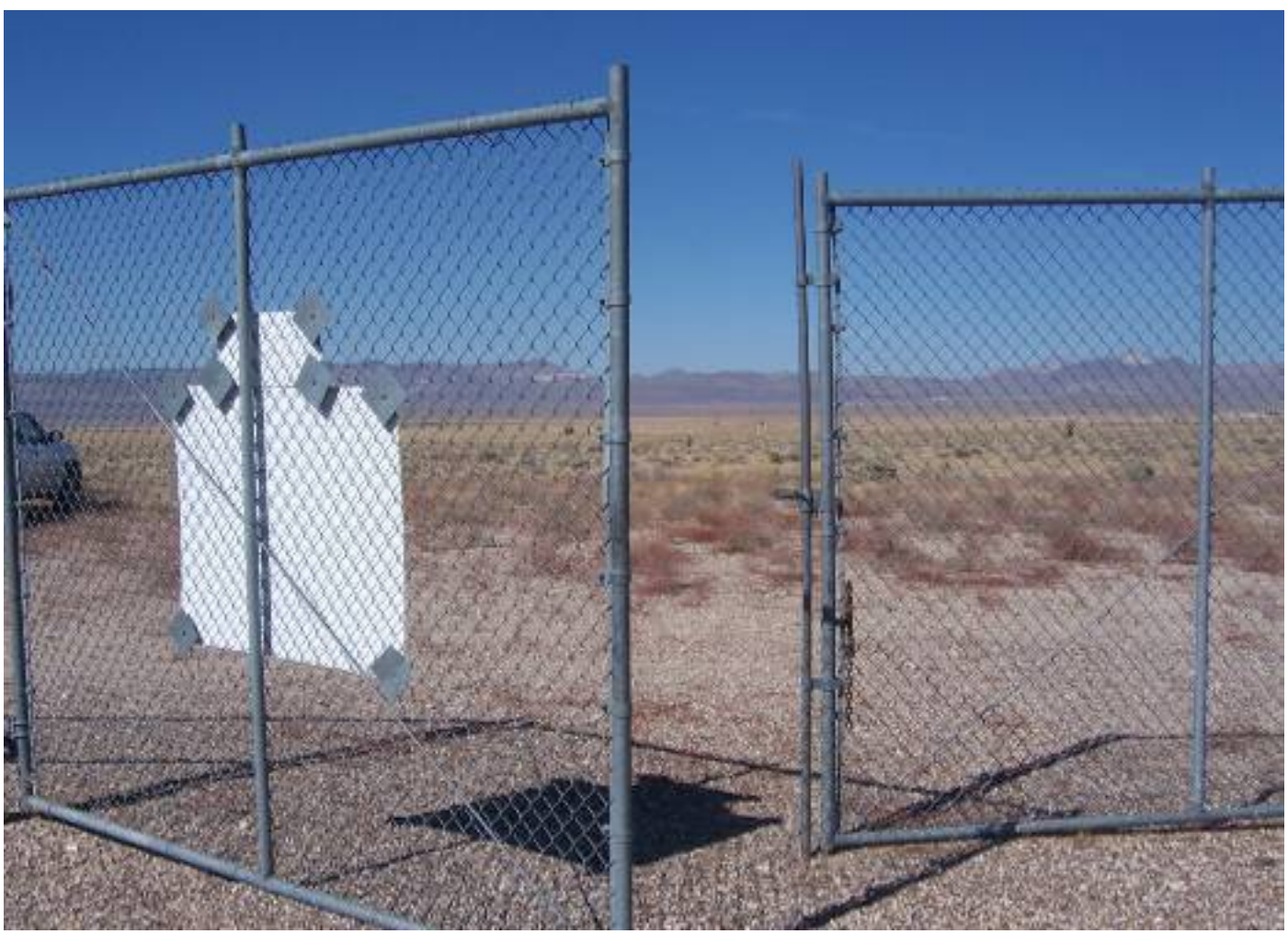

Photograph 14: CAU 91, Inside Facing West, 09/23/2008 


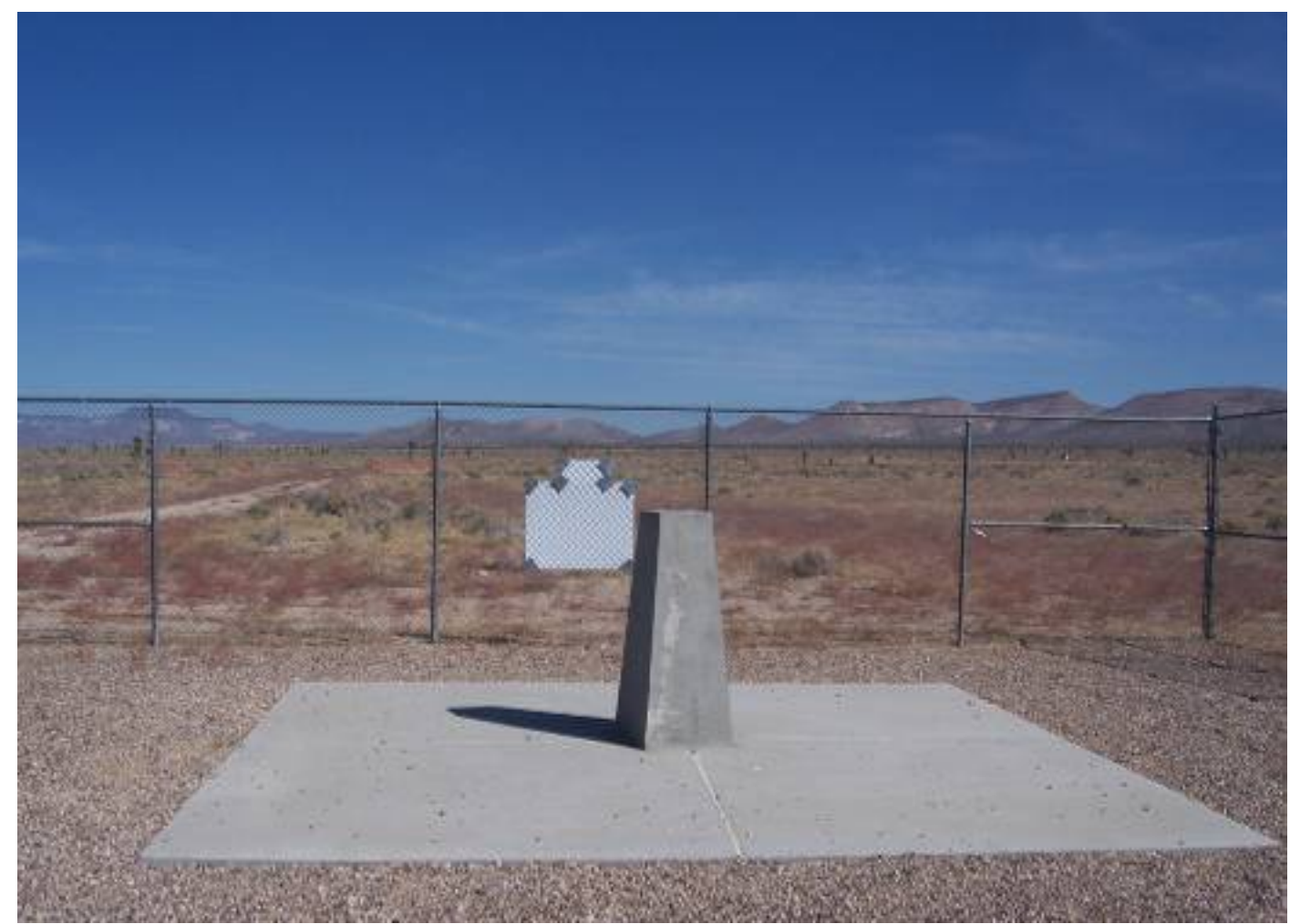

Photograph 15: CAU 91, Surface Monument Facing North, 09/23/2008

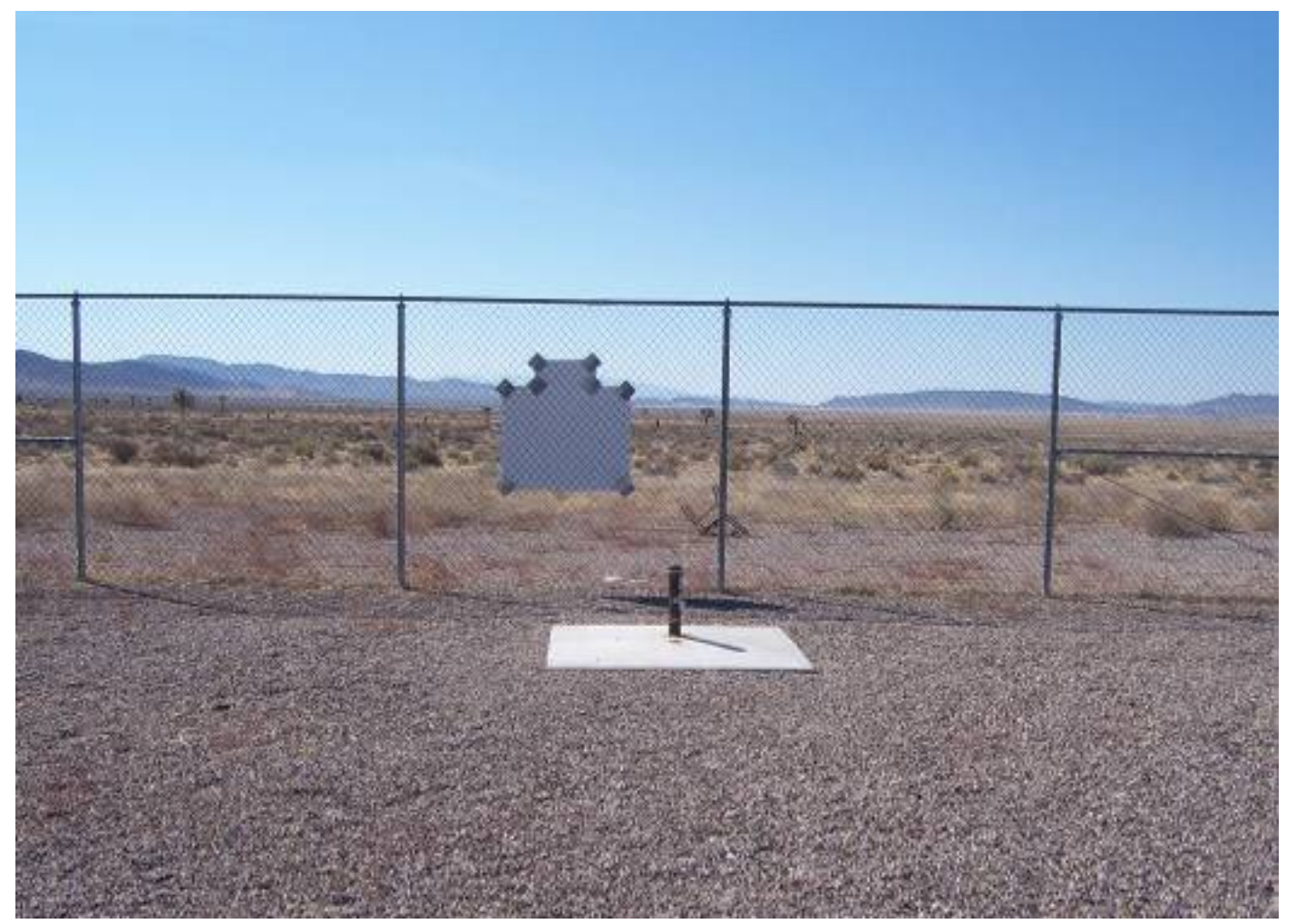

Photograph 16: CAU 91, Surface Monitoring Well Facing South, 09/23/2008 


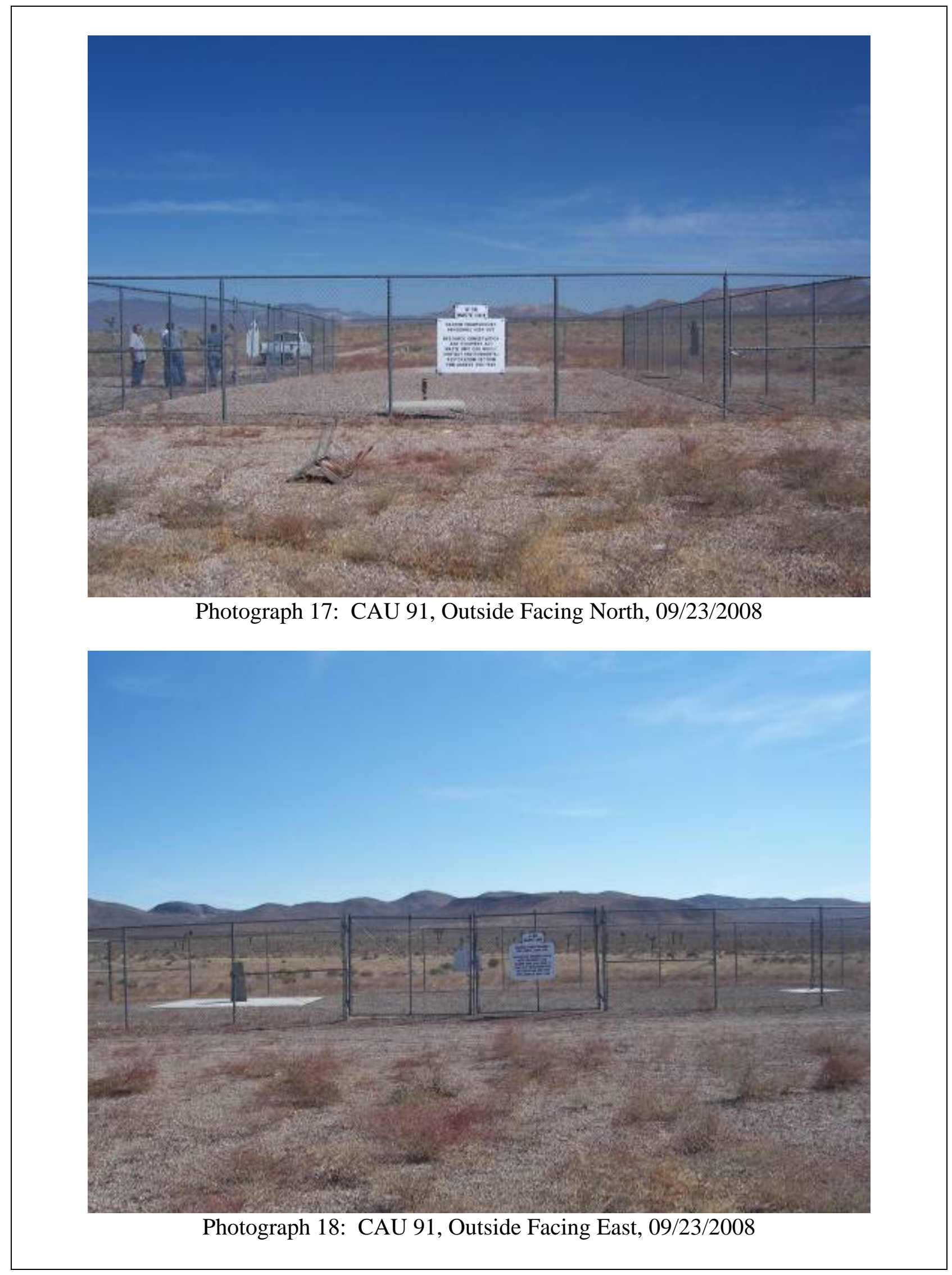




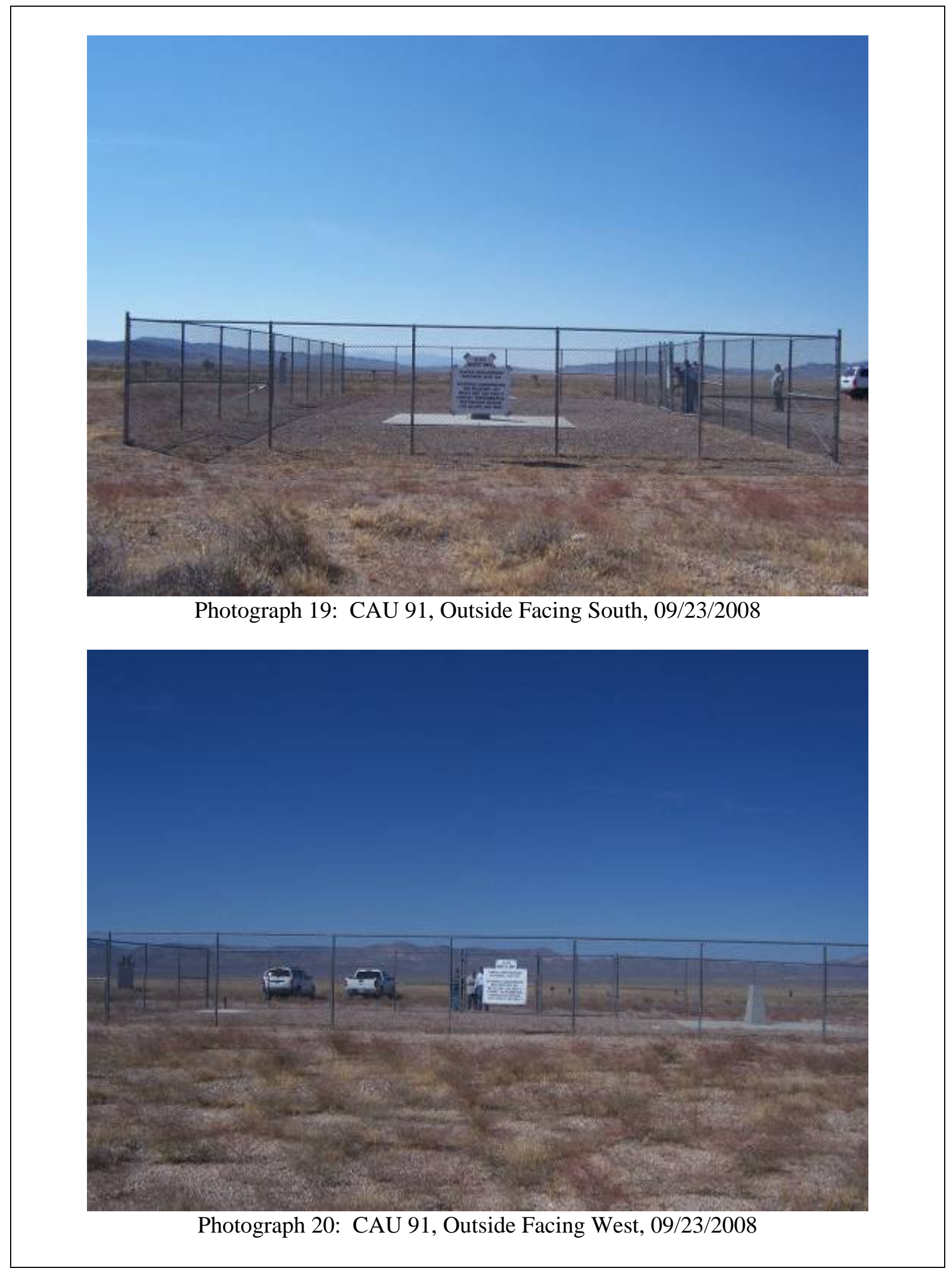




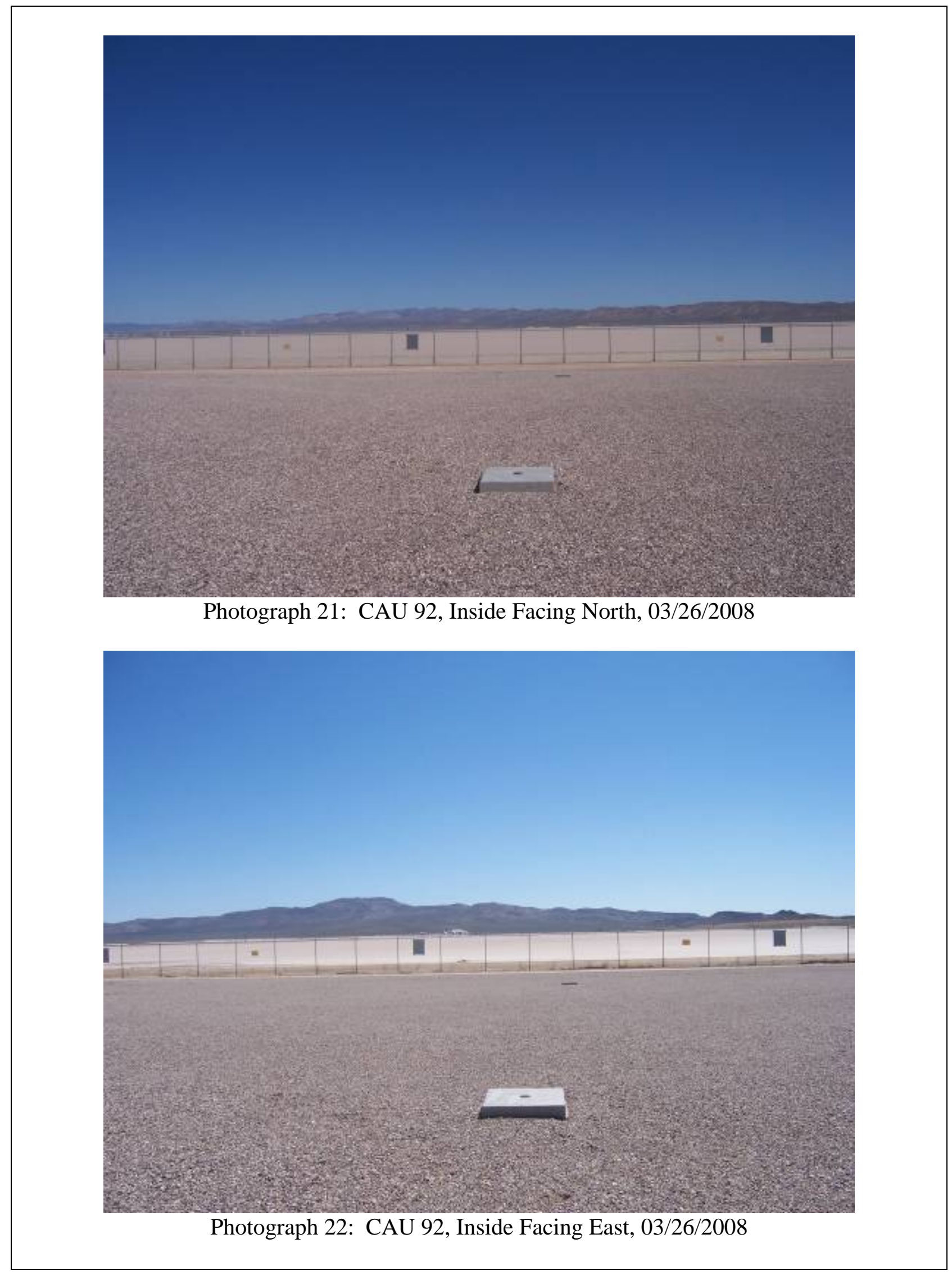




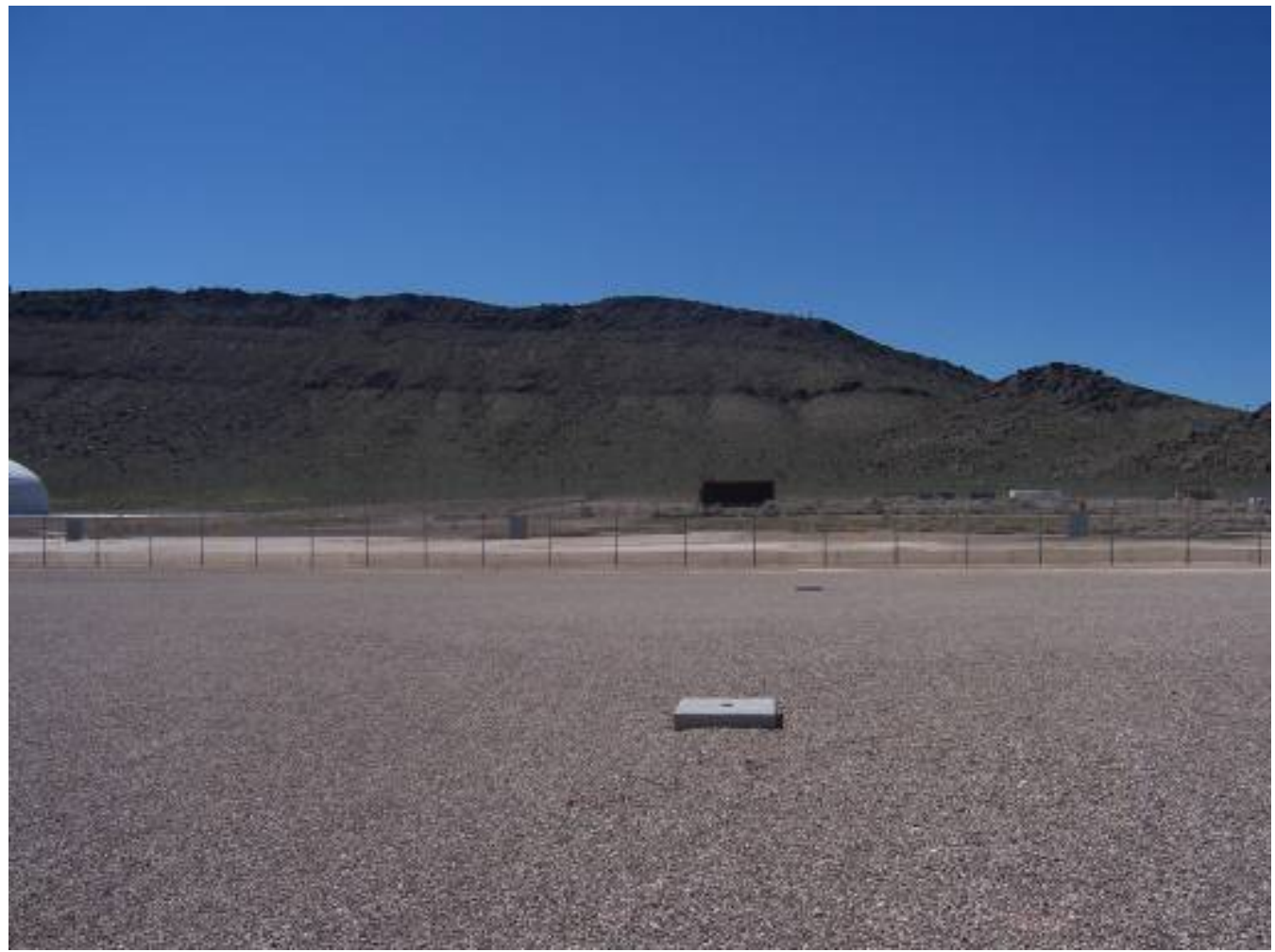

Photograph 23: CAU 92, Inside Facing South, 03/26/2008

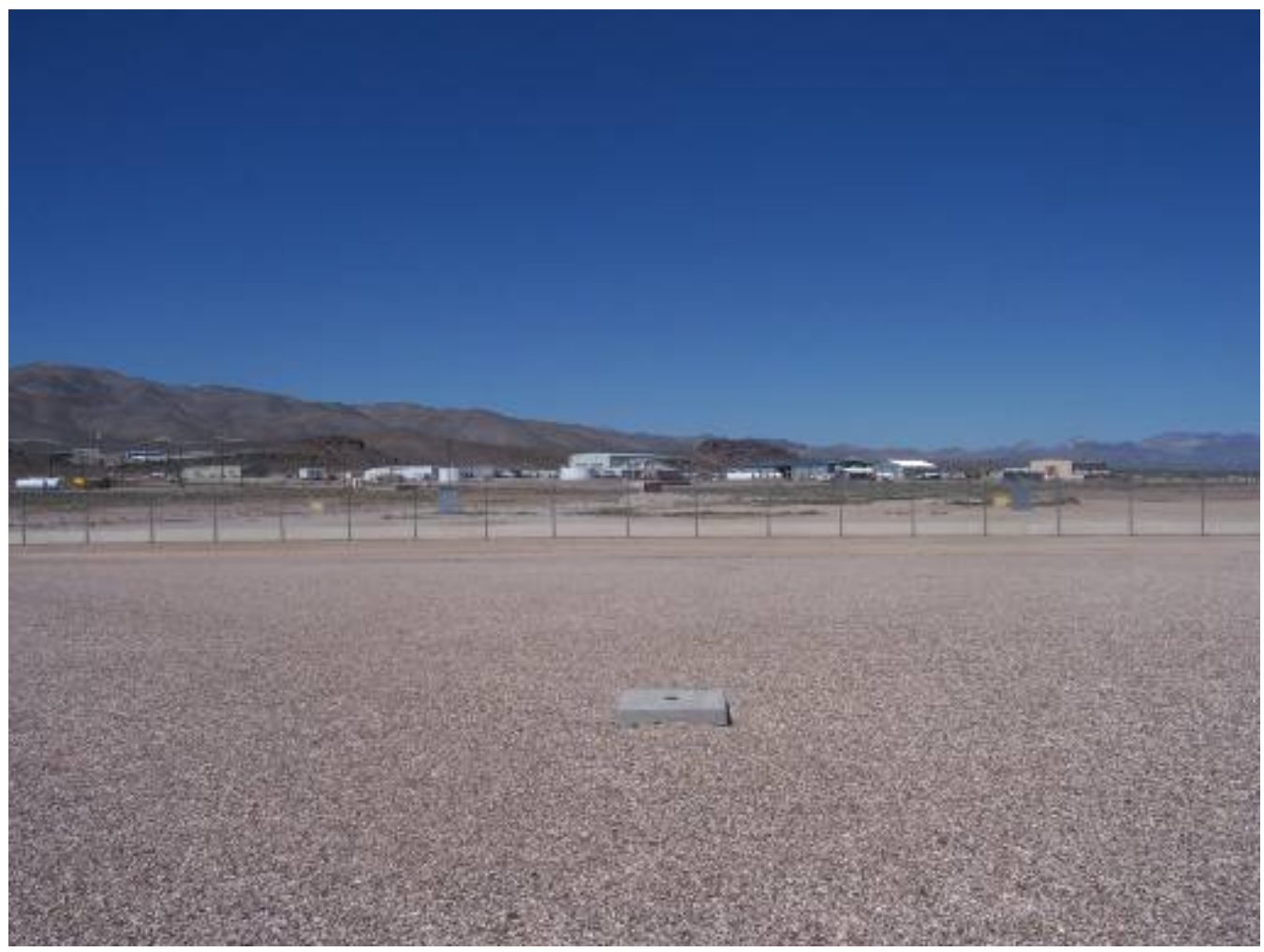

Photograph 24: CAU 92, Inside Facing West, 03/26/2008 


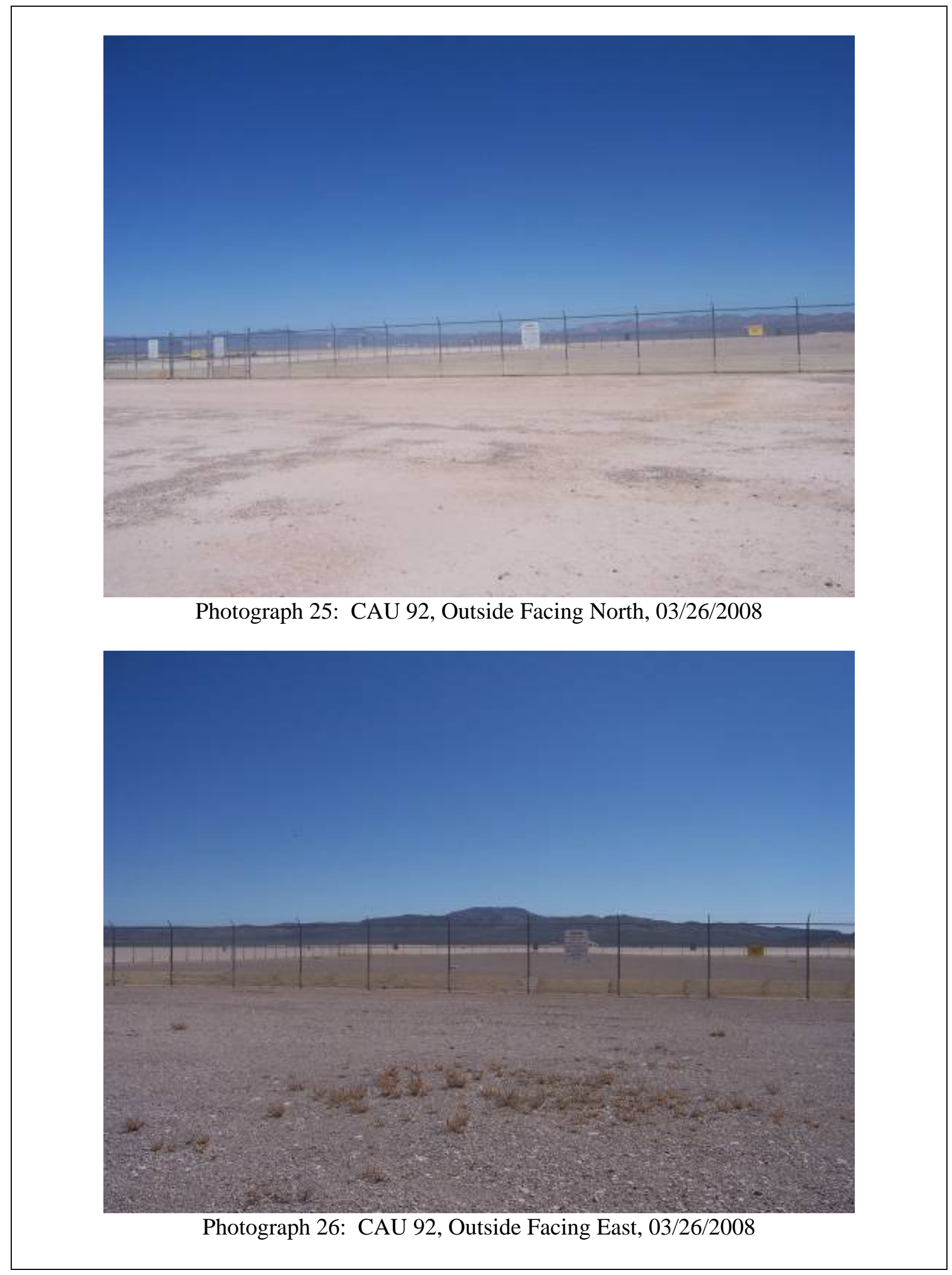




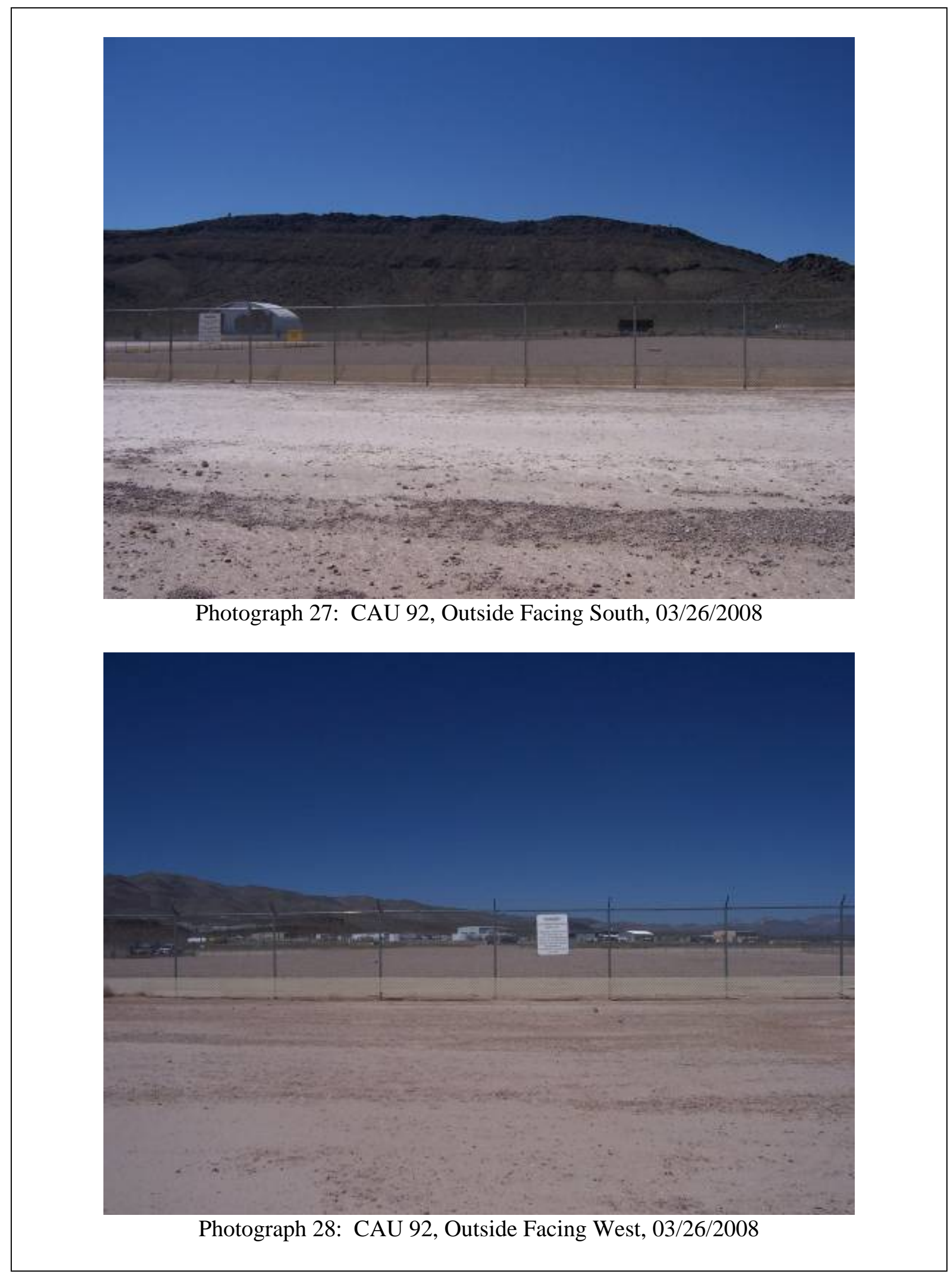




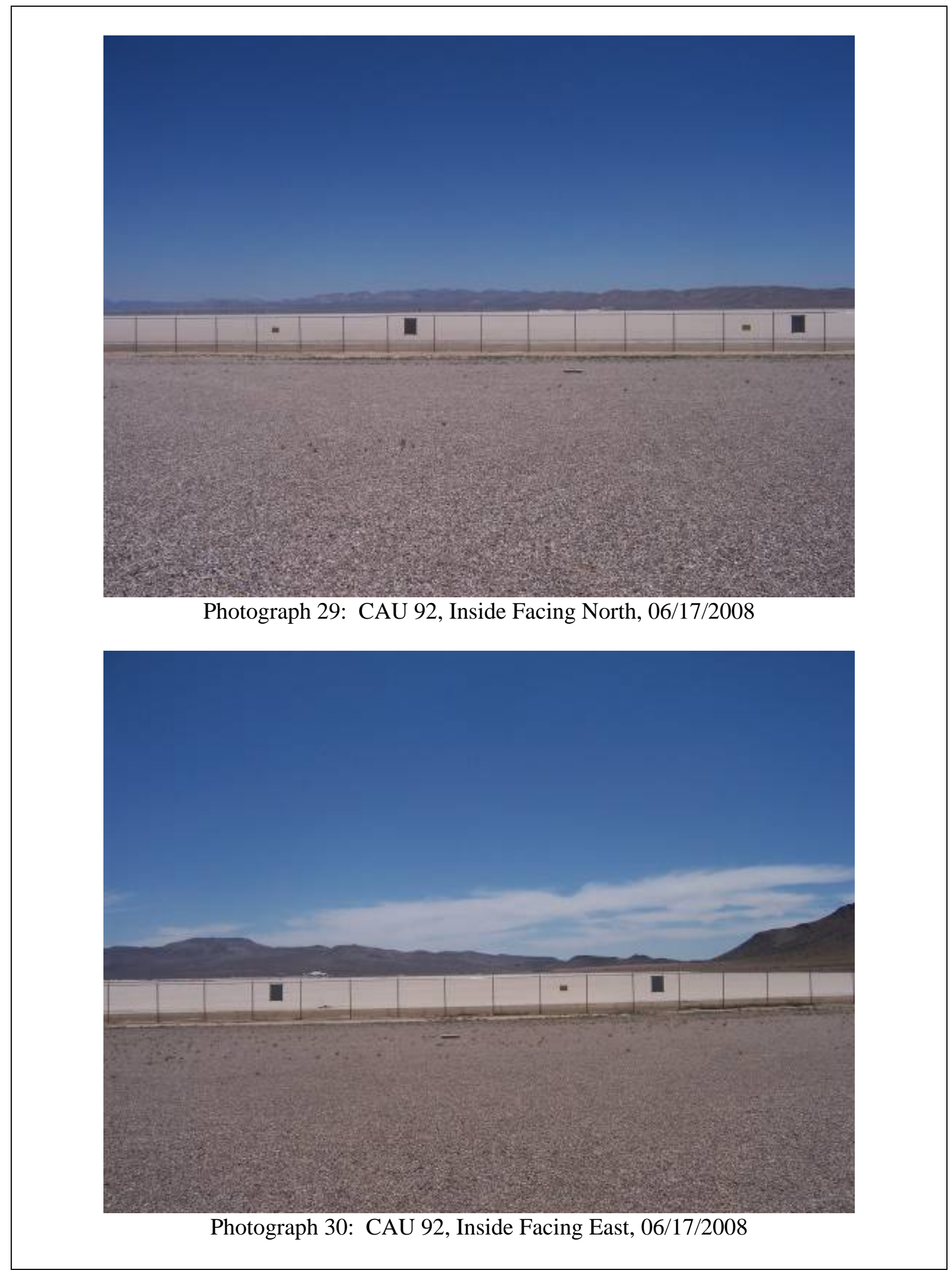




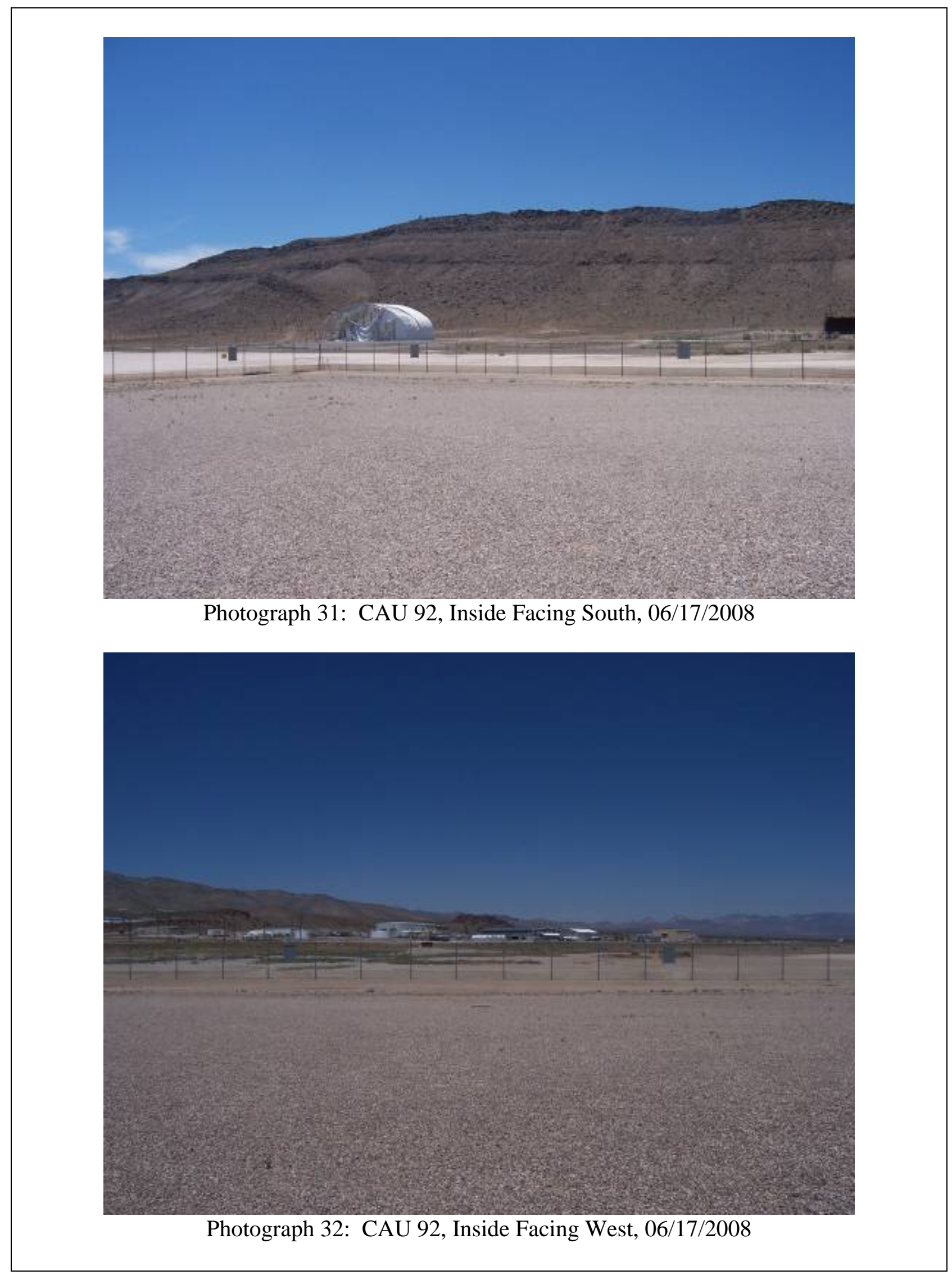




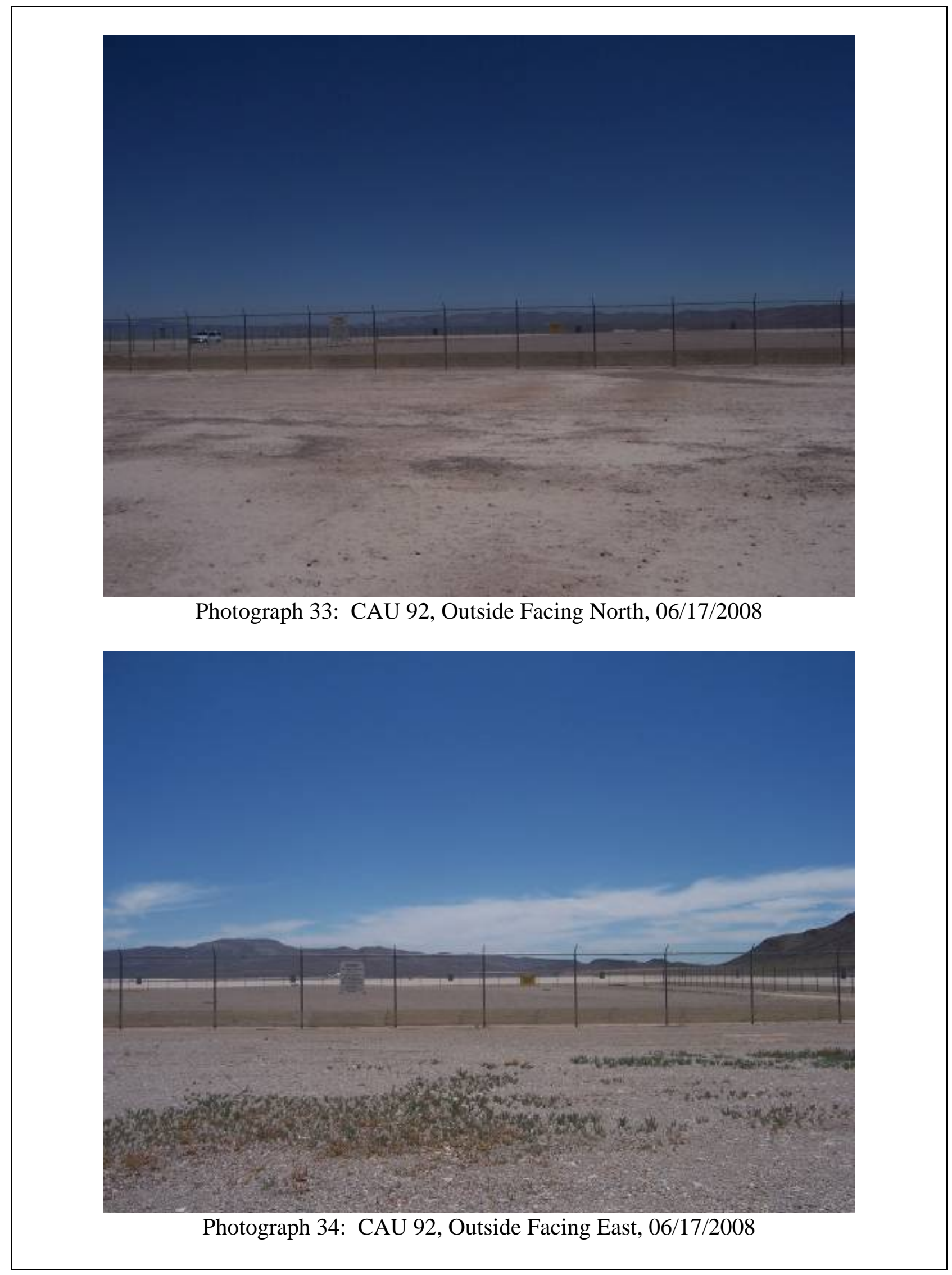




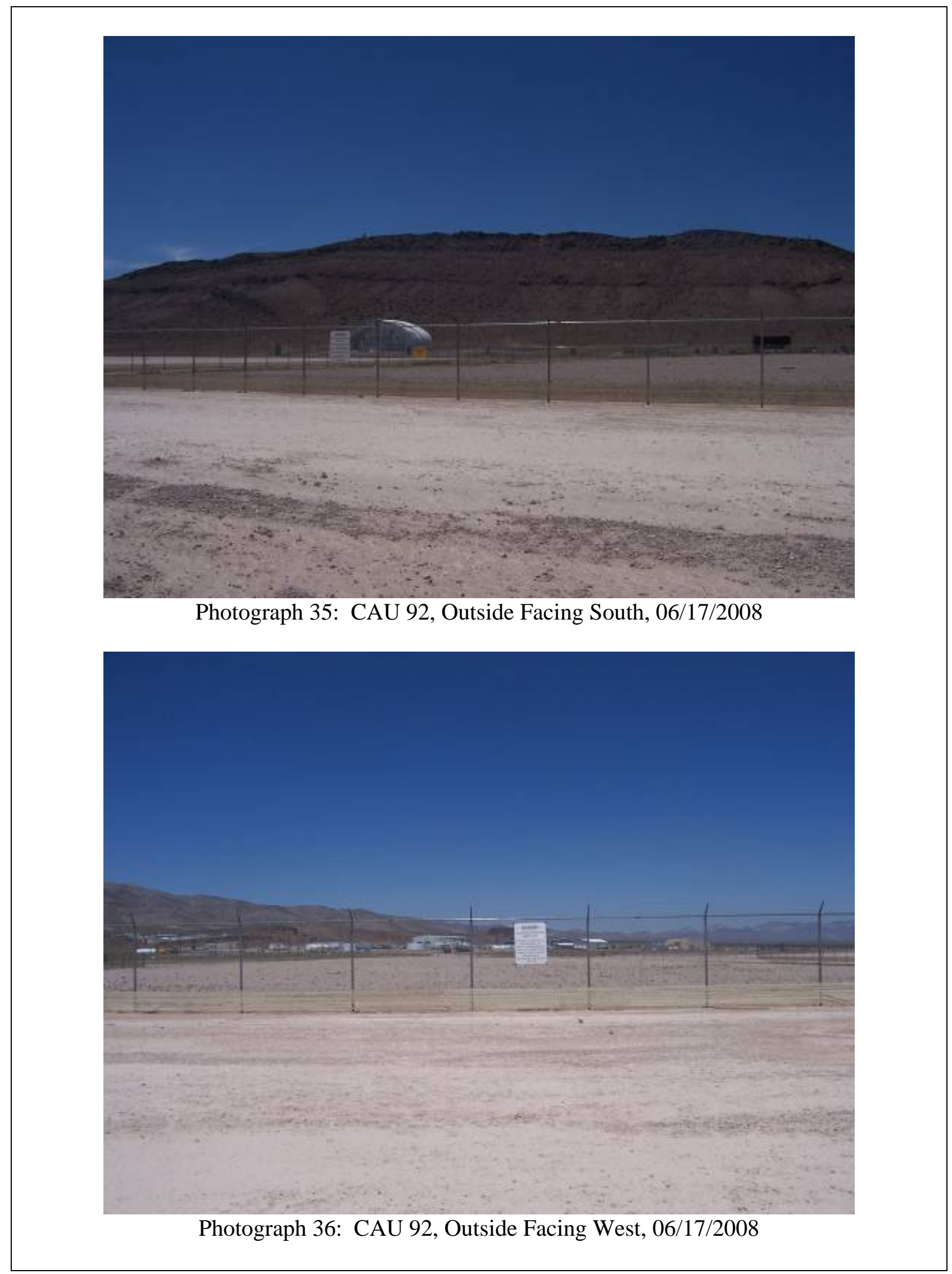




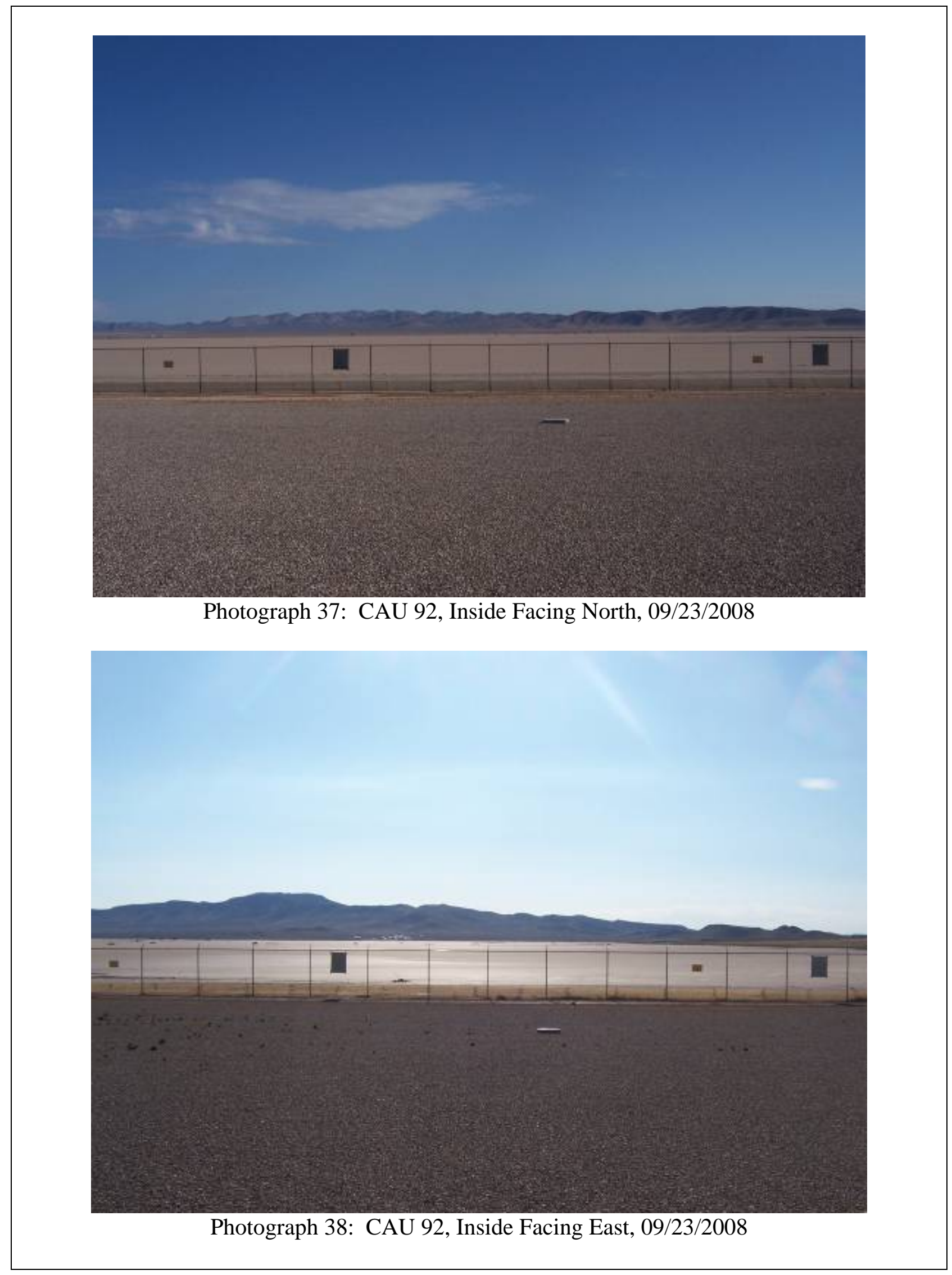




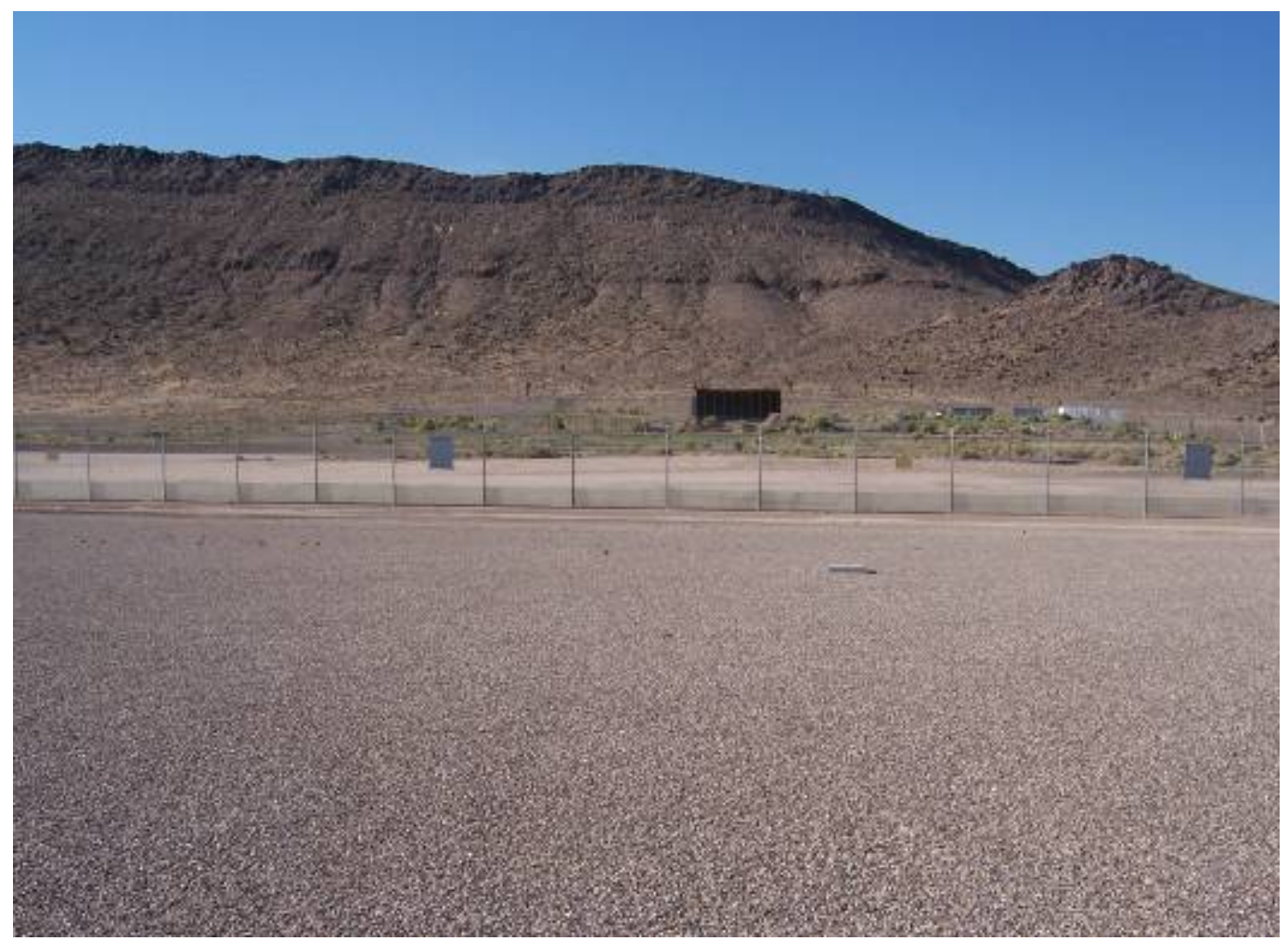

Photograph 39: CAU 92, Inside Facing South, 09/23/2008

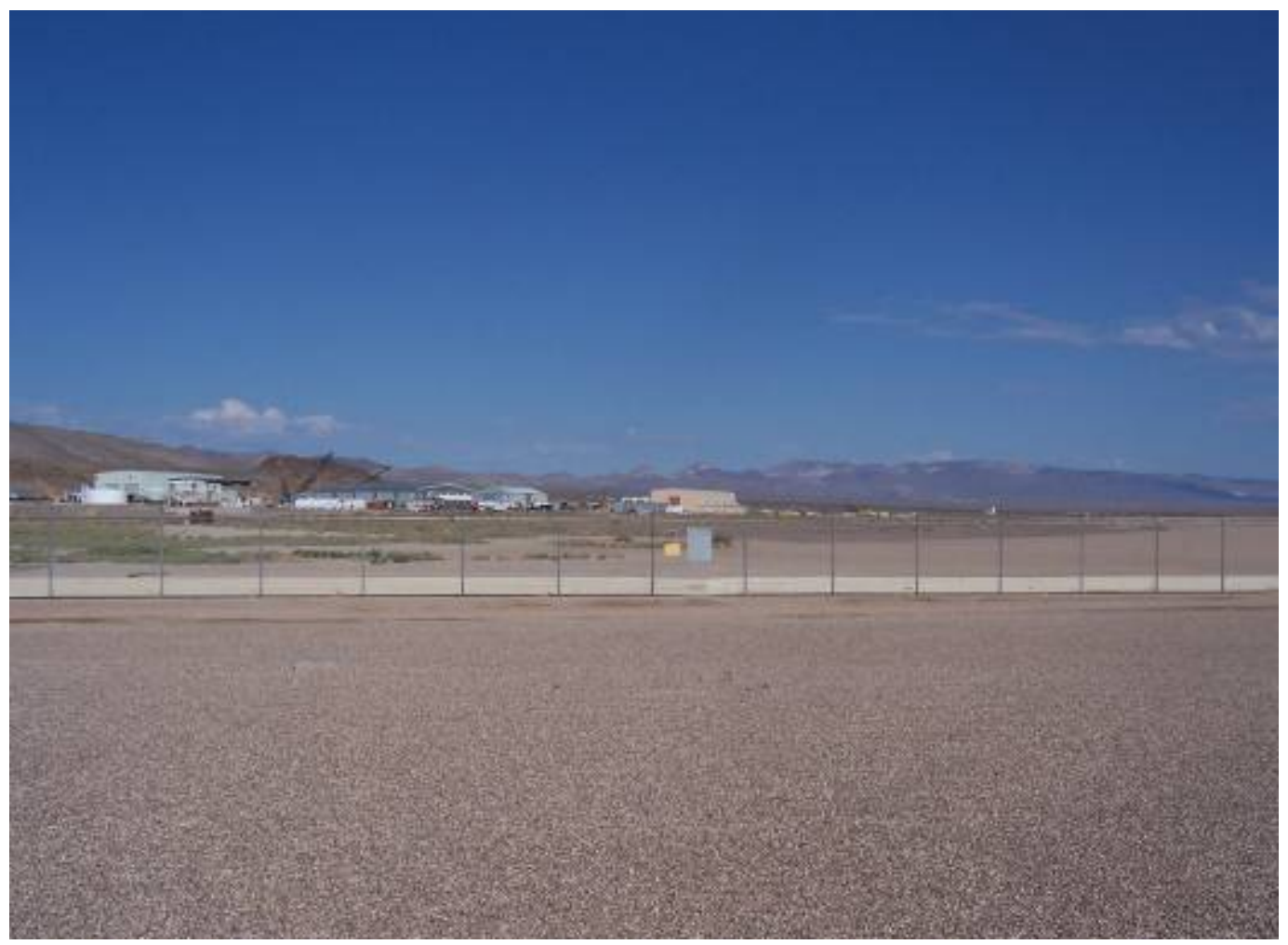

Photograph 40: CAU 92, Inside Facing West, 09/23/2008 


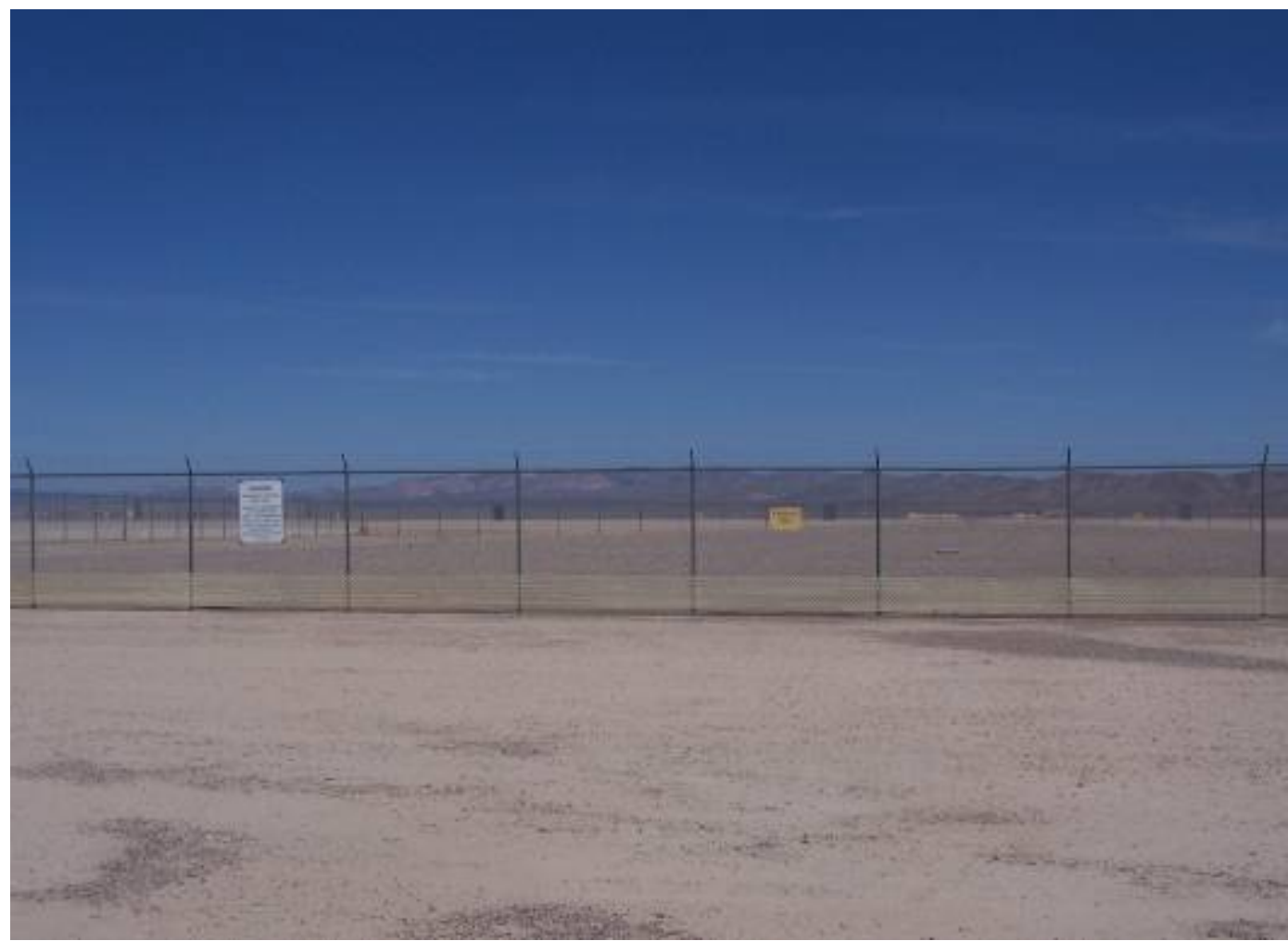

Photograph 41: CAU 92, Outside Facing North, 09/23/2008

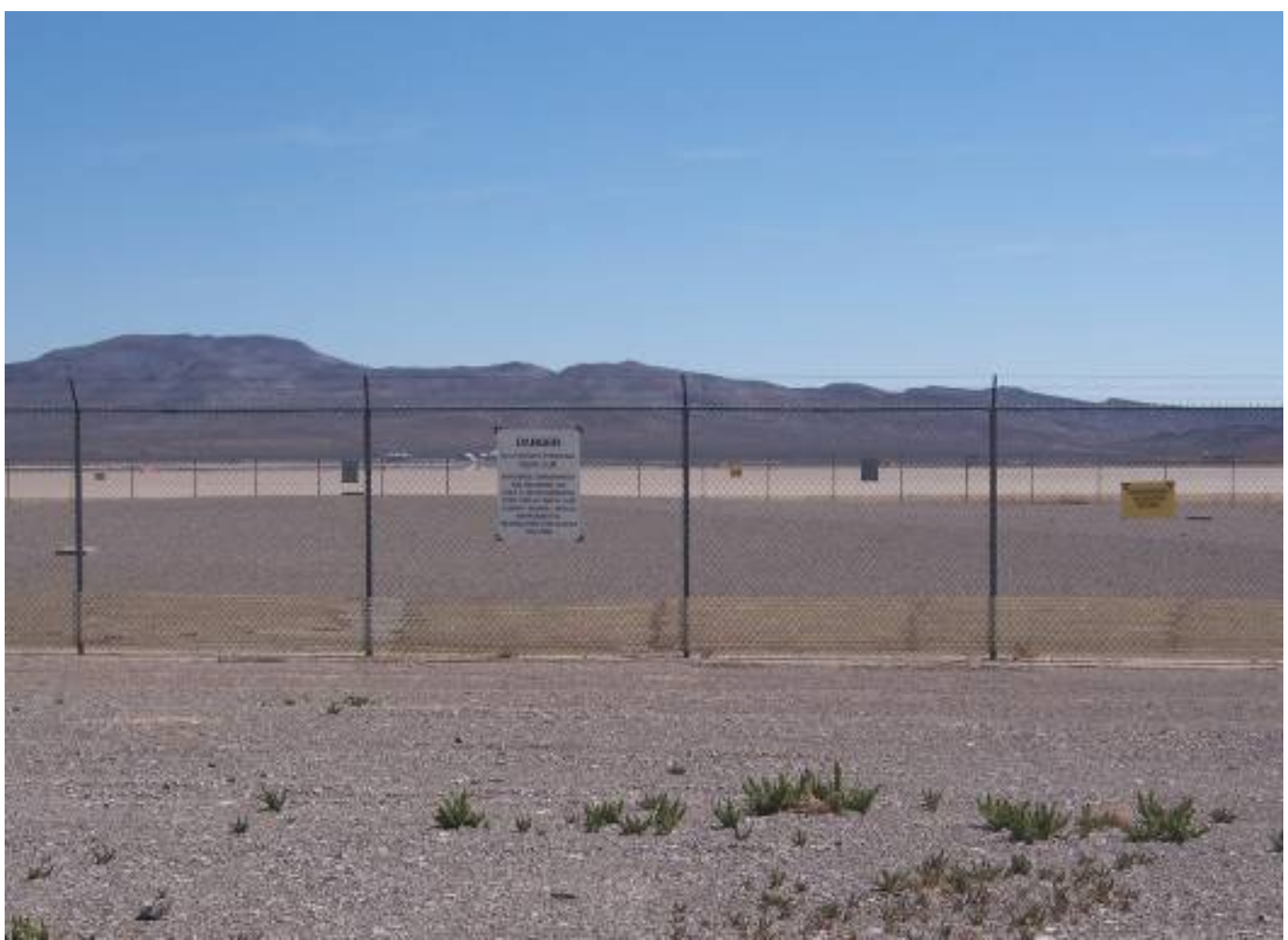

Photograph 42: CAU 92, Outside Facing East, 09/23/2008 


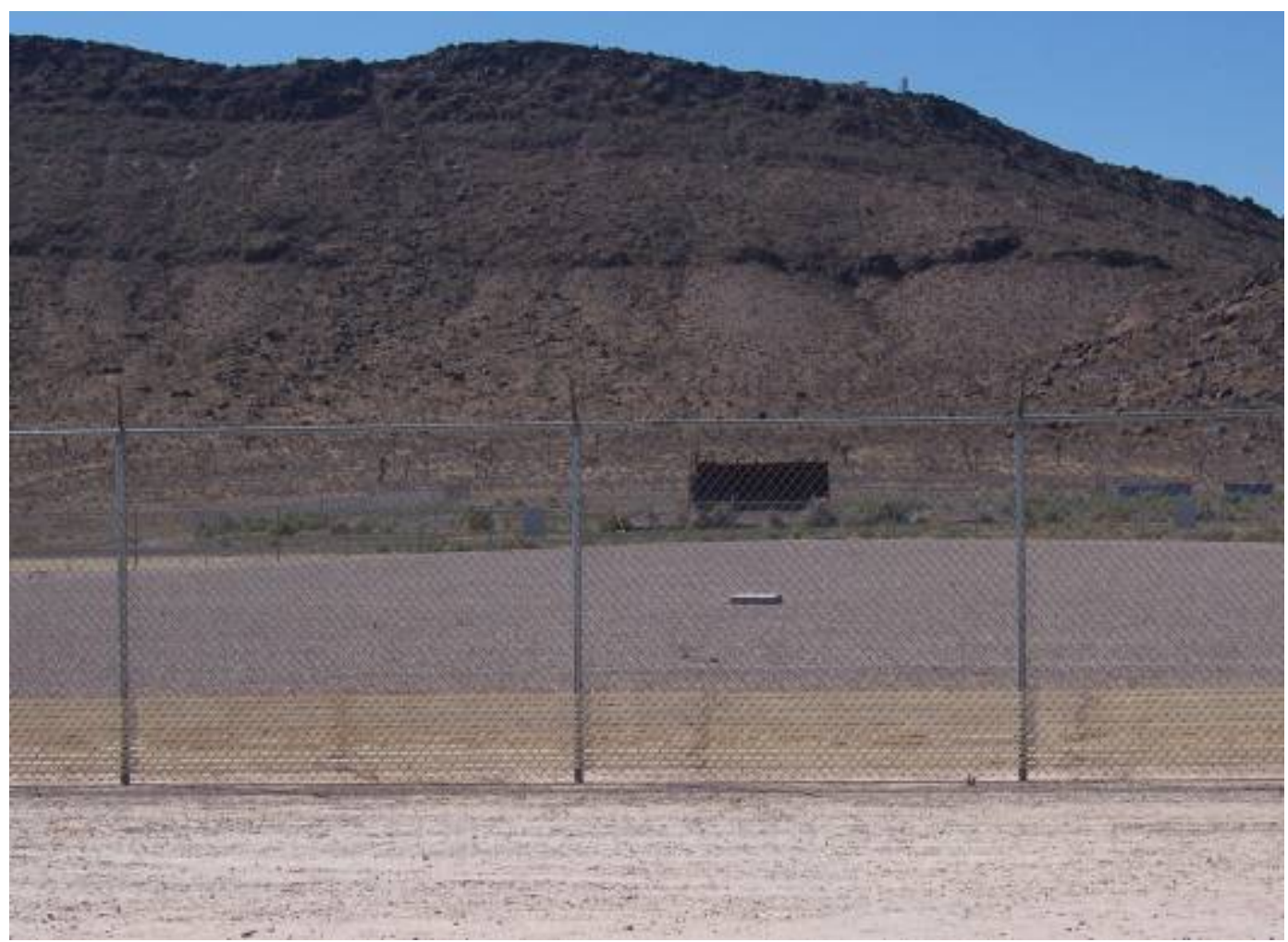

Photograph 43: CAU 92, Outside Facing South, 09/23/2008

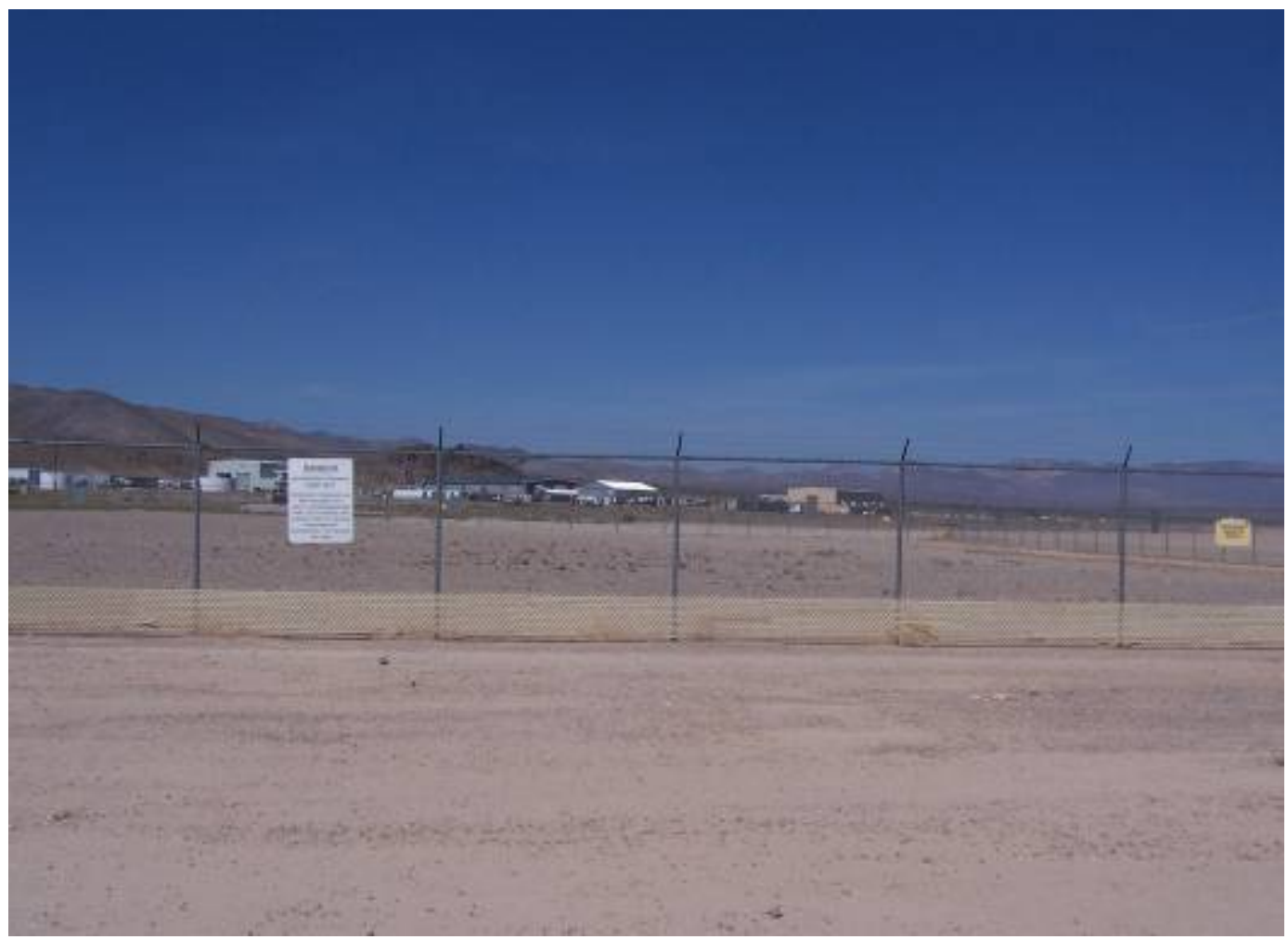

Photograph 44: CAU 92, Outside Facing West, 09/23/2008 


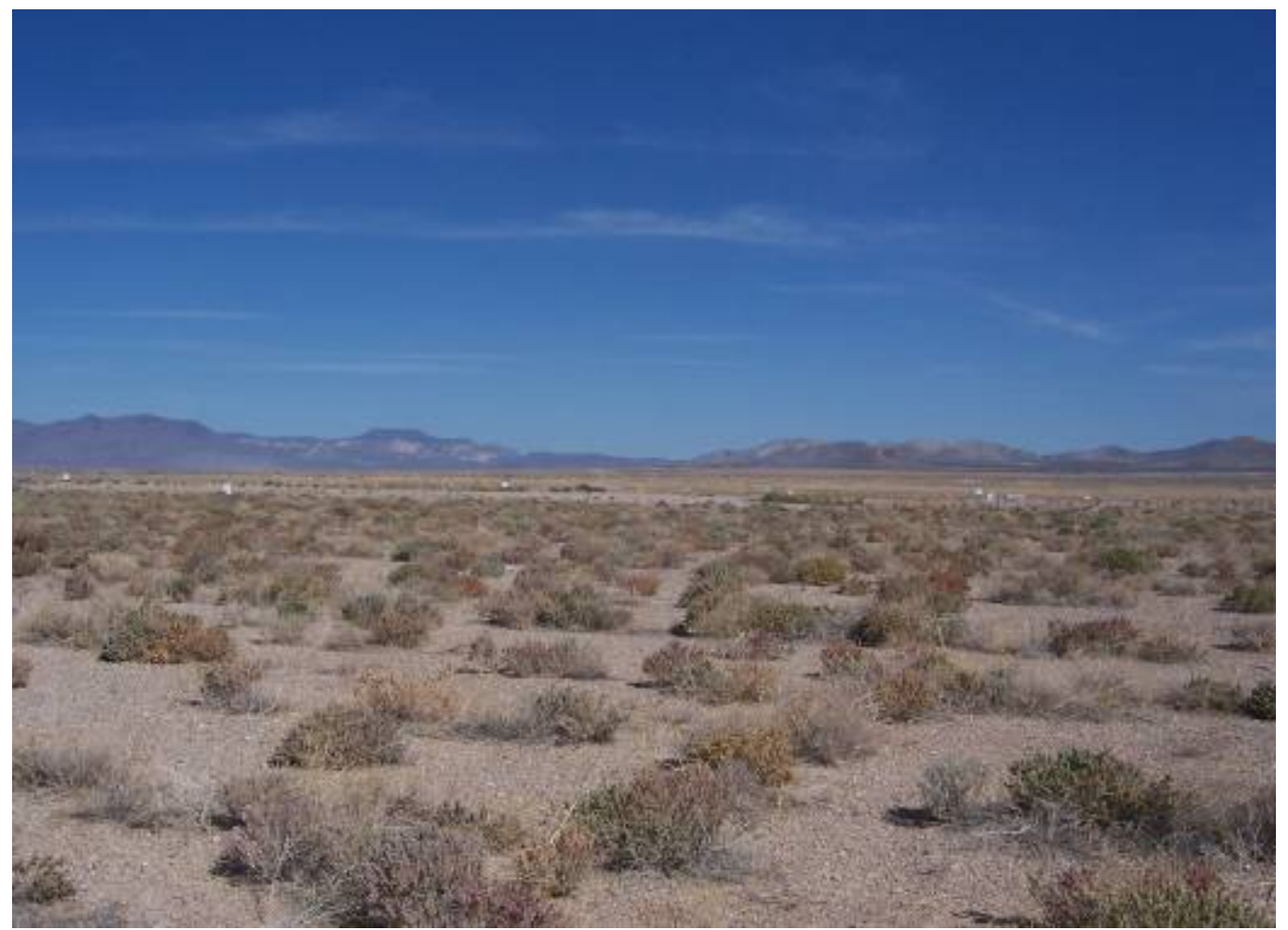

Photograph 45: CAU 110, Inside Facing North, 09/23/2008

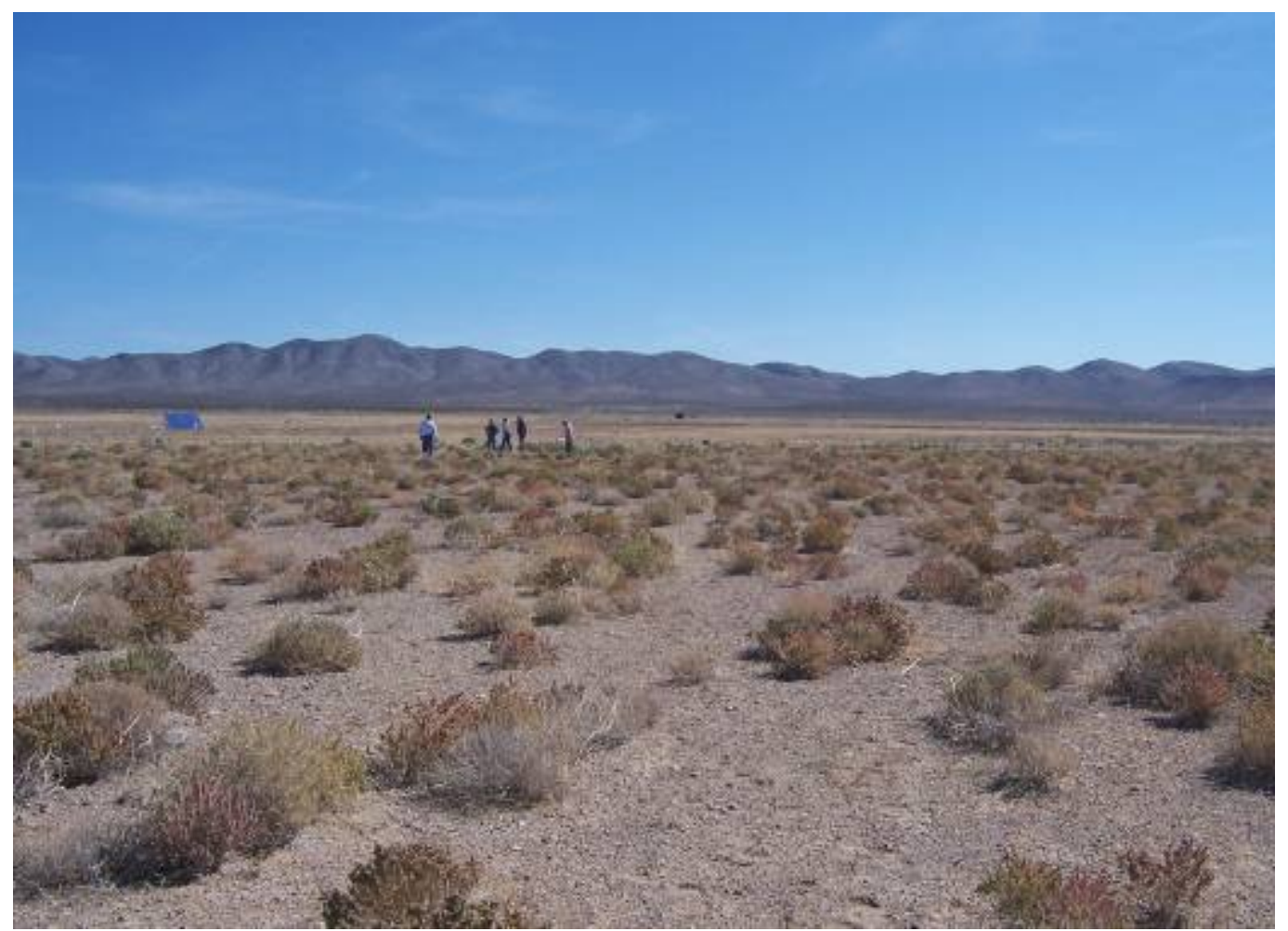

Photograph 46: CAU 110, Inside Facing East, 09/23/2008 


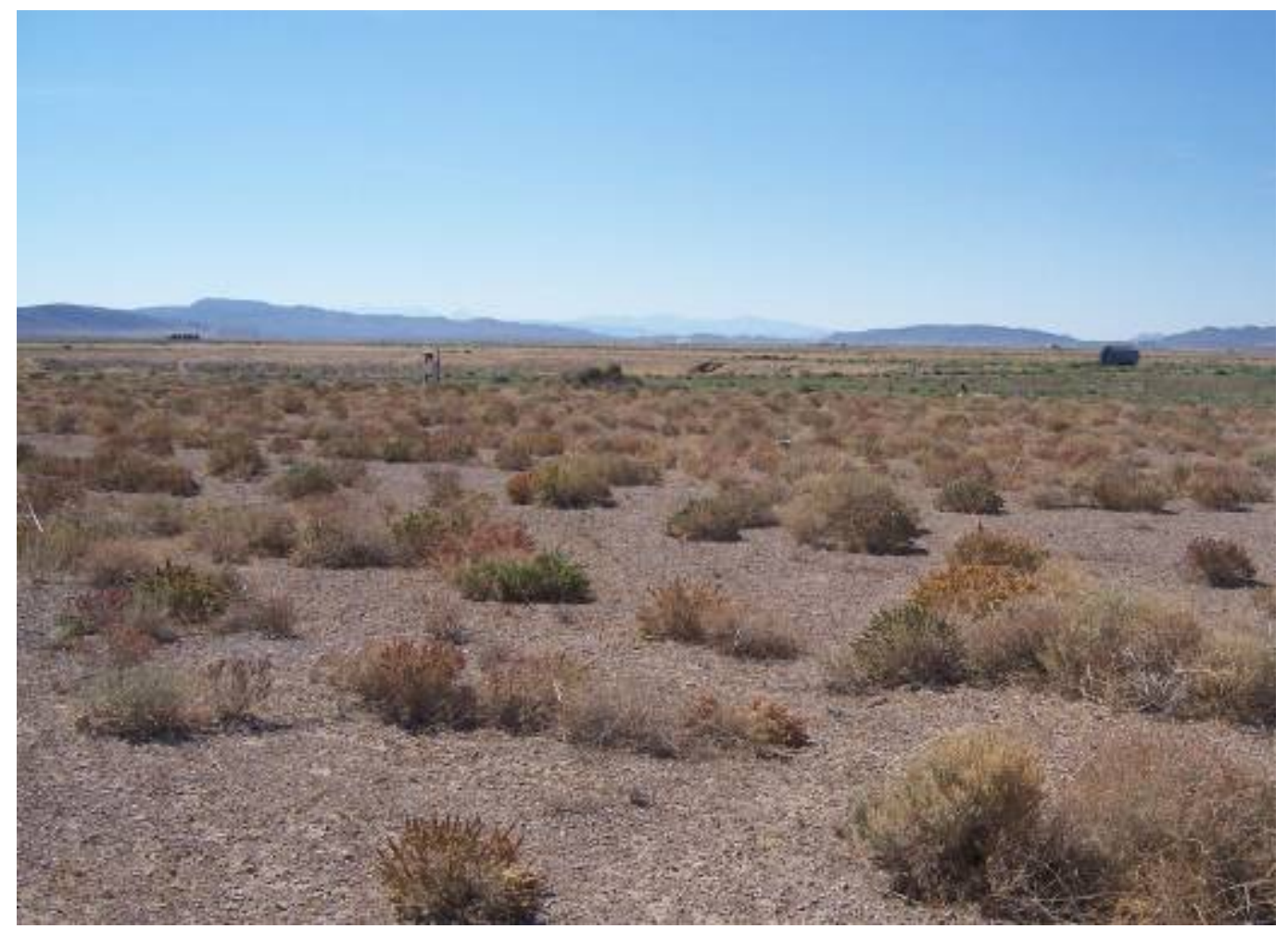

Photograph 47: CAU 110, Inside Facing South, 09/23/2008

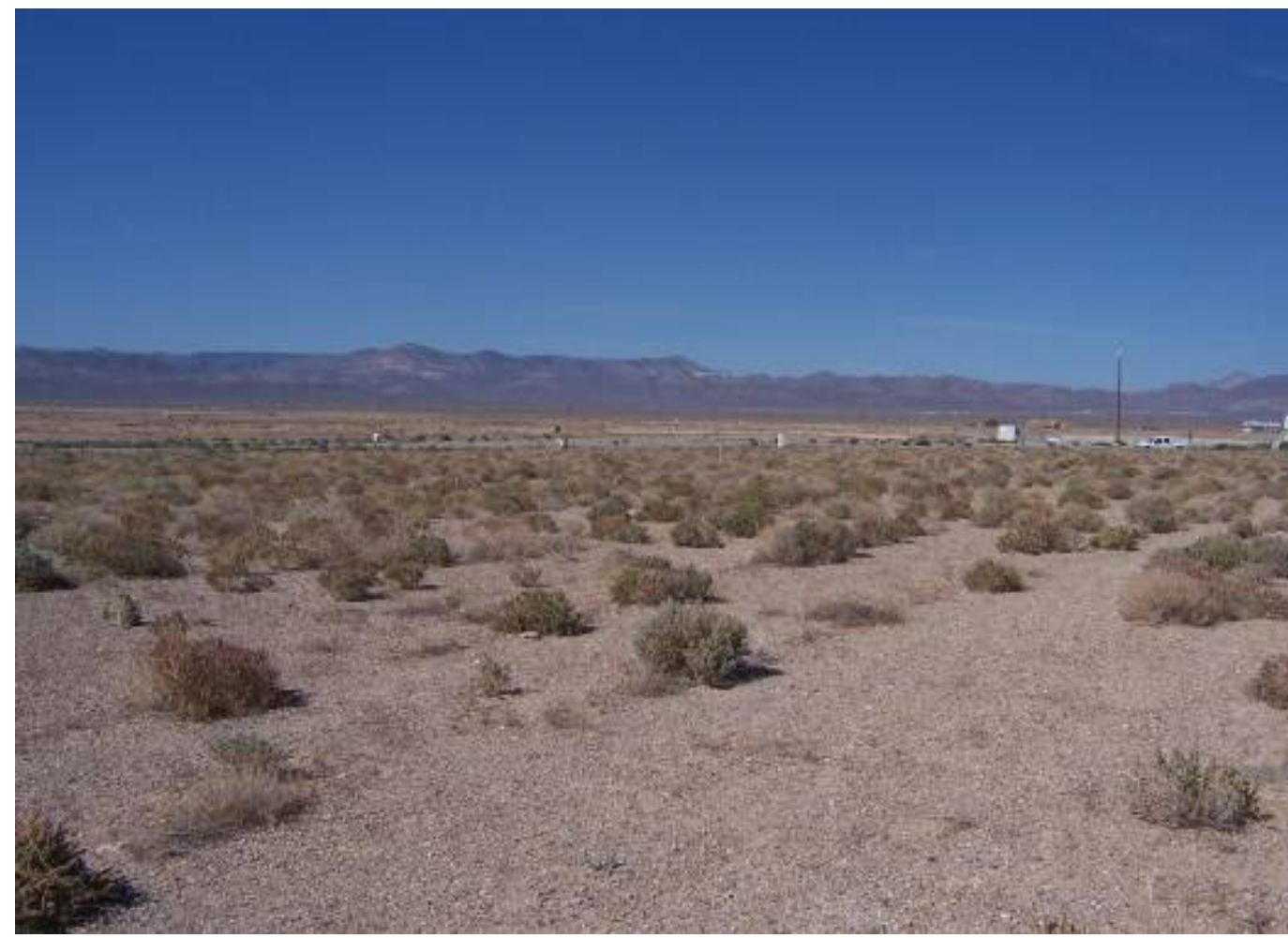

Photograph 48: CAU 110, Inside Facing West, 09/23/2008 


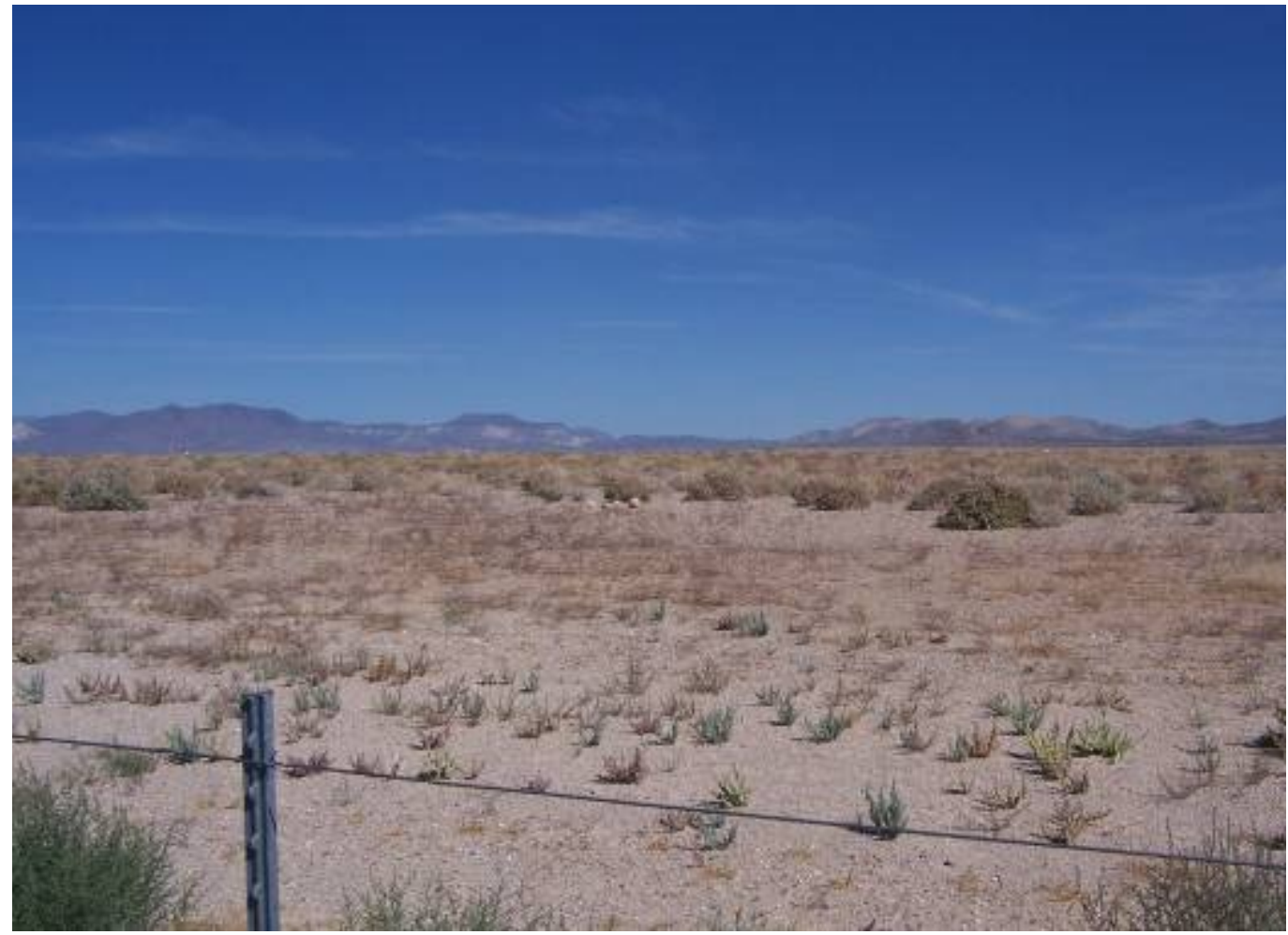

Photograph 49: CAU 110, Outside Facing North, 09/23/2008

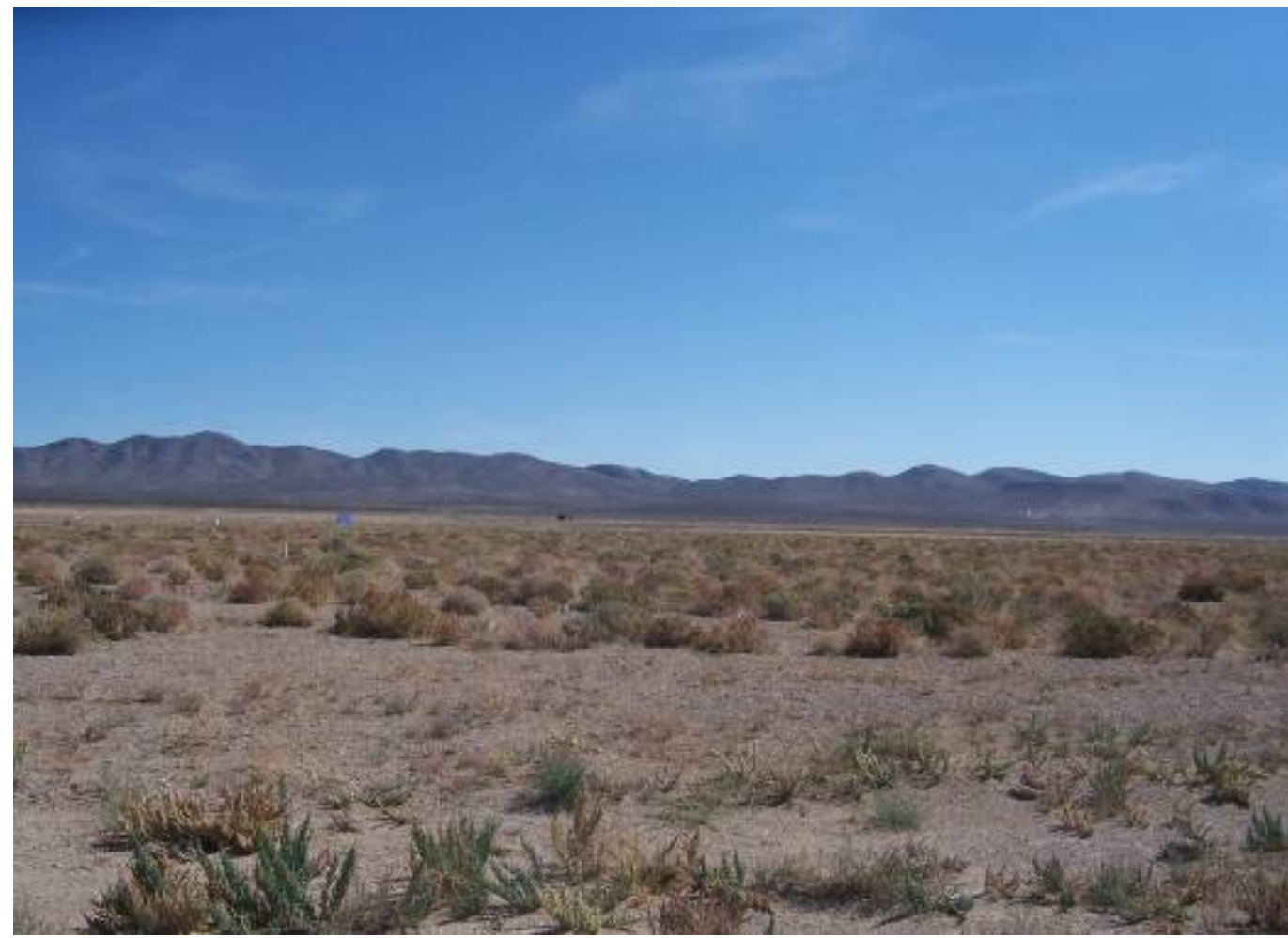

Photograph 50: CAU 110, Outside Facing East, 09/23/2008 


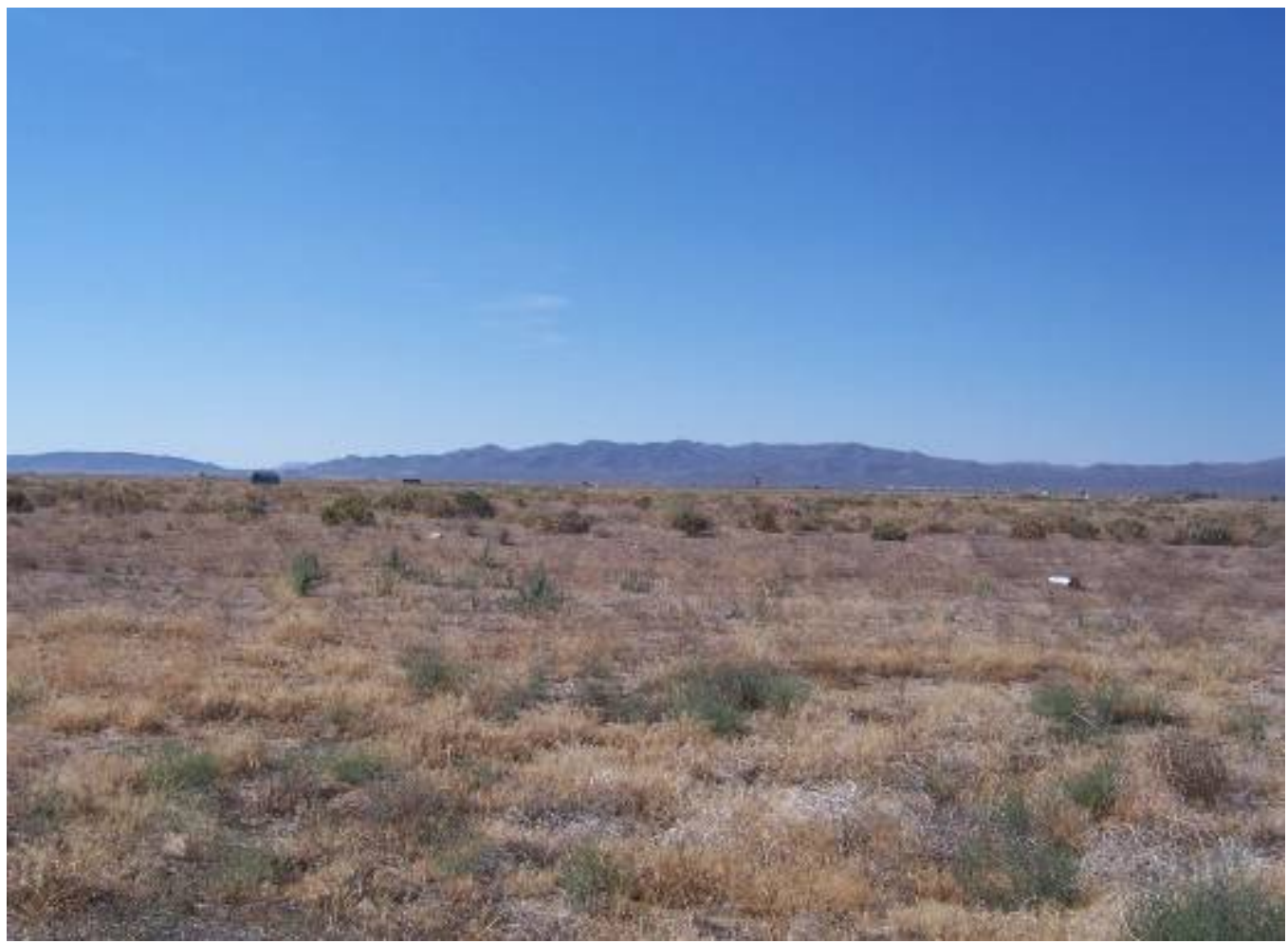

Photograph 51: CAU 110, Outside Facing South, 09/23/2008

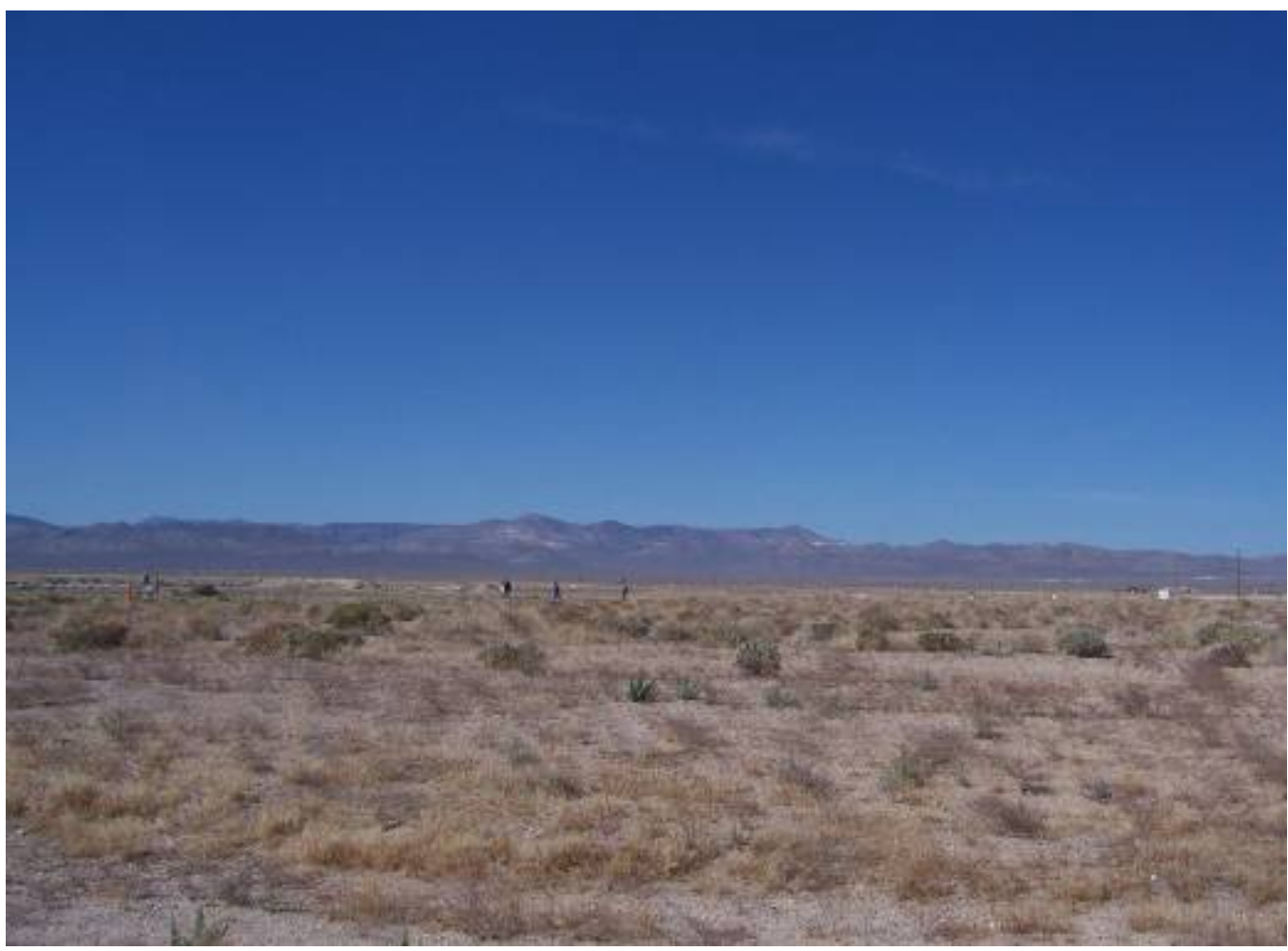

Photograph 52: CAU 110, Outside Facing West, 09/23/2008 
RCRA Post-Closure Report

Revision: 0

Date: December 2008

\section{LIBRARY DISTRIBUTION LIST}


RCRA Post-Closure Report

Revision: 0

Date: December 2008

THIS PAGE INTENTIONALLY LEFT BLANK 


\section{LIBRARY DISTRIBUTION LIST}

U.S. Department of Energy

National Nuclear Security Administration

Nevada Site Office

Technical Library

P.O. Box 98518, M/S 505

Las Vegas, NV 89193-8518

U.S. Department of Energy

Office of Scientific and Technical Information

P.O. Box 62

Oak Ridge, TN 37831-0062

Southern Nevada Public Reading Facility

c/o Nuclear Testing Archive

P.O. Box 98521, M/S 400

Las Vegas, NV 89193-8521

Manager, Northern Nevada FFACO

Public Reading Facility

c/o Nevada State Library \& Archives

Carson City, NV 89701-4285
1 (Uncontrolled, electronic copy)

1 (Uncontrolled, electronic copy)

2 (Uncontrolled, electronic copies)

1 (Uncontrolled, electronic copy) 
RCRA Post-Closure Report

Revision: 0

Date: December 2008

THIS PAGE INTENTIONALLY LEFT BLANK 